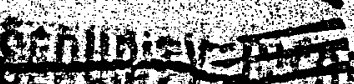

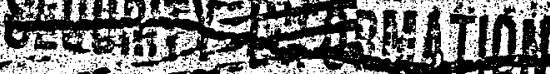
MU THESPEDW

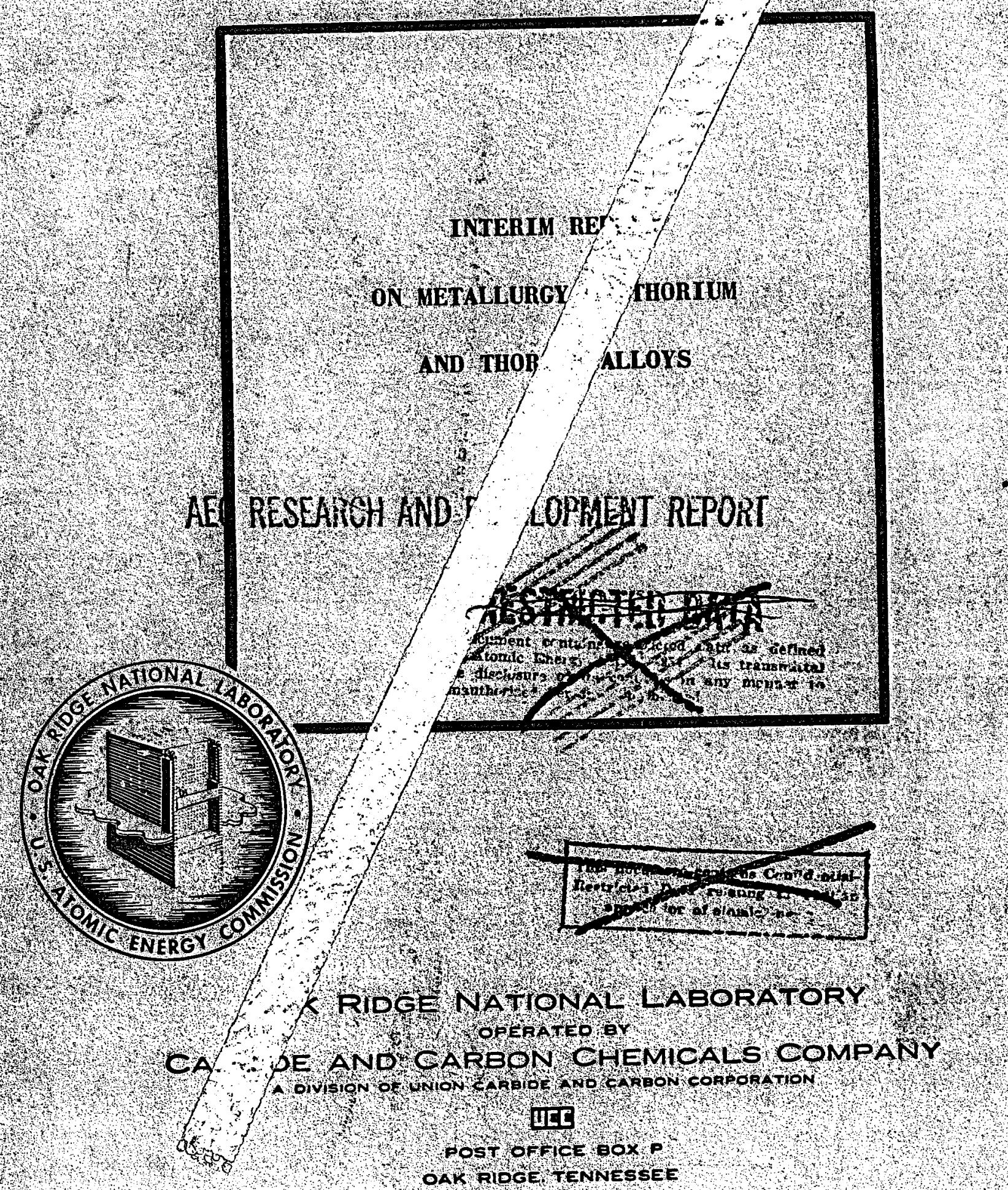




\section{DISCLAIMER}

This report was prepared as an account of work sponsored by an agency of the United States Government. Neither the United States Government nor any agency Thereof, nor any of their employees, makes any warranty, express or implied, or assumes any legal liability or responsibility for the accuracy, completeness, or usefulness of any information, apparatus, product, or process disclosed, or represents that its use would not infringe privately owned rights. Reference herein to any specific commercial product, process, or service by trade name, trademark, manufacturer, or otherwise does not necessarily constitute or imply its endorsement, recommendation, or favoring by the United States Government or any agency thereof. The views and opinions of authors expressed herein do not necessarily state or reflect those of the United States Government or any agency thereof. 


\section{DISCLAIMER}

Portions of this document may be illegible in electronic image products. Images are produced from the best available original document. 


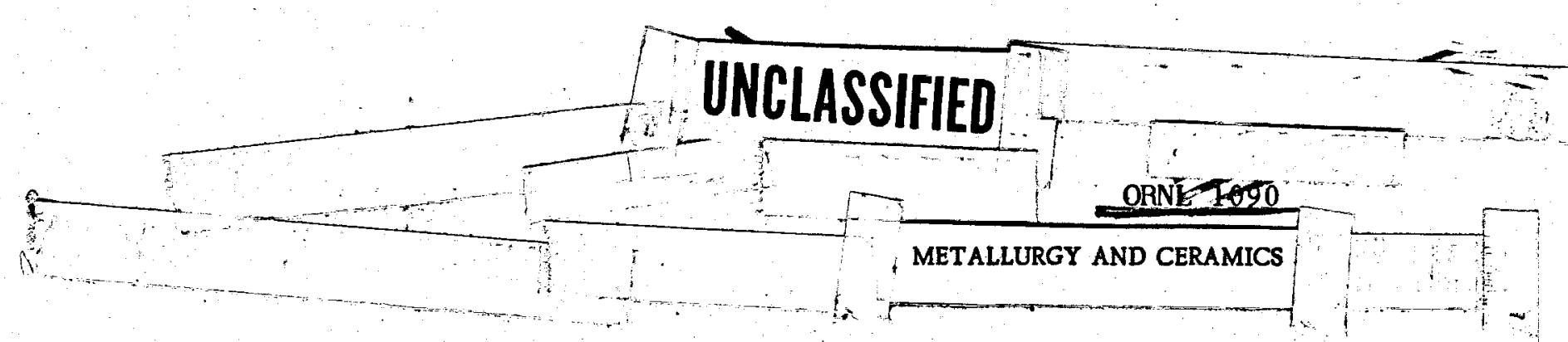

This document is

PUBLICLY RELEASABTA

B Steel

Authorizing Official

Date:

3122106

\title{
AND THORIUM ALLOYS
}

\author{
METALLURGY DIVISION
}

J. H. Frye, Jr., Director

Period Covered by Work: July 1, 1949 to July 1, 1951

Work Carried Out By:

Mechanical Testing:

W. D. Manly

R. E. Adams

D. E. Hamby

Fabrication: $\quad$ J. H. Erwin

R. E. Adams
Welding:

Alloy Development and $\mathrm{NaK}$ Cycling:
P. Patriarca

R. E. Adams

D. E. Hamby
Corrosion Testing:

Metallography:
R. J. Gray
A. R. Olsen (Reactor Experimental Engineering Division)

X-ray Diffraction:

B. S. Borie

Prices 0.60
$\begin{aligned} & \text { Available from the } \\ & \text { Office of Technical Services } \\ & \text { Department of Commerce } \\ & \text { Washington 25, D.C. }\end{aligned}$

Report Writtén By:

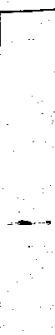

D. E. Hamb CLASSIFICATTON CAMCELLED

Date Issued

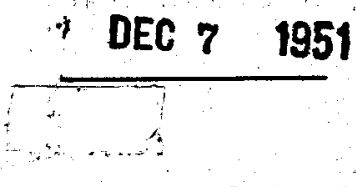

DATE

MAR 41957 For The Atomic Enerey Commianion -76 . (1) Chitef Deciacalfication Eranch

\section{Operated by}

CARBIDE AND CARBON CHEMICALS COMPANY

A Division of Union Carbide and Carbon Corporation

Post Office Box $P$

LEGAL NOTICE

Oak Ridge, Tennessee

This report was prepared as an account of Government sponsared work. Nelther the United States, nor the Commission, nor any person acting on behalf of the Commission:

A. Makes any warranty or represenfation, express or implied, with respect to the accuracy, completeness, or usefulness of the information contained in this report, or that the use of any information, apporatus, method, or process disclosed in this report may not infringe privately owned rights; or

B. Assumes any liabilities with respect to the use of, or for damages resulting from the use of any information, apparatus, method, or process disclosed in this report.

As used in the above, "person acting on behalf of the Commission" includes any employee or contractor of the Commission to the extent that such employee or contractor prepares, handles or distributes, or provides access to, any information pursuant to his employment or contract with the Commission. 


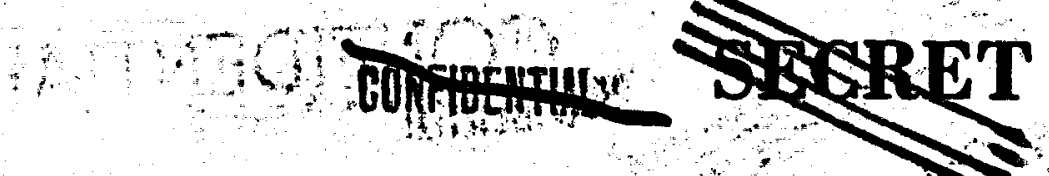

INTERIM REPORT ON METALLURGY OF THORIUM AND THORIUM OYS

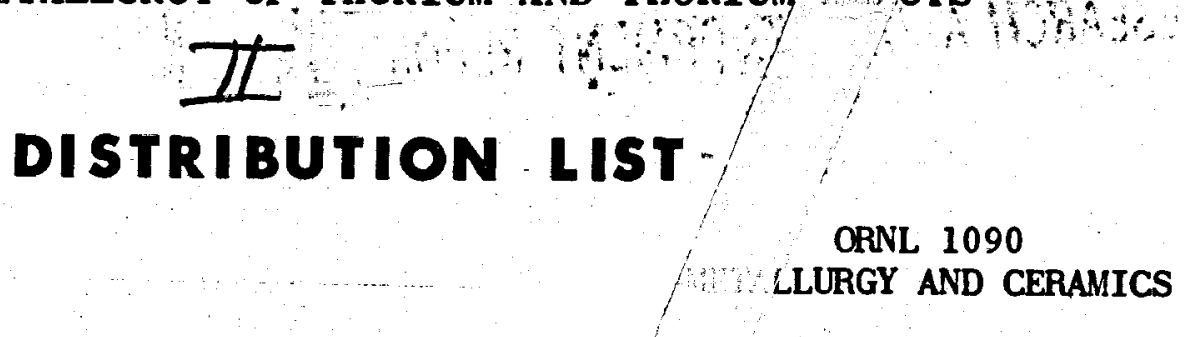

INTERNAL

1. G. T. Felbeck (C\&CCC)

2-3. Chemistry Library

4. Physics Library

5. Biology Library

6. Health Physics Library

7. Metallurgy Library

8-9. Training School Library

10-13. Central Files

14. C. E. Center

15. C. E. Larson

16. W. B. Humes $(K-25)$

17. W. D. Lavers $(Y-12)$

18. A. M. Weinberg

19. E. H. Taylor

20. E. D. Shipley

21. F. C. VonderLage

22. R. C. Briant

23. J. A. Swartout

24. S. C. Lind

25. F. L. Steahly

26. A. H. Snell

27. A. Hollaender

28. M. T. Kelley

\section{INTERNAL}

LURGY AND CERAMICS

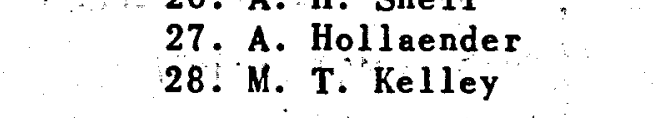

\section{RESTICTEN MTI}

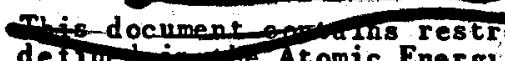

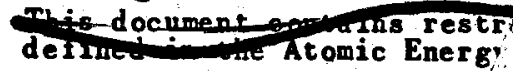

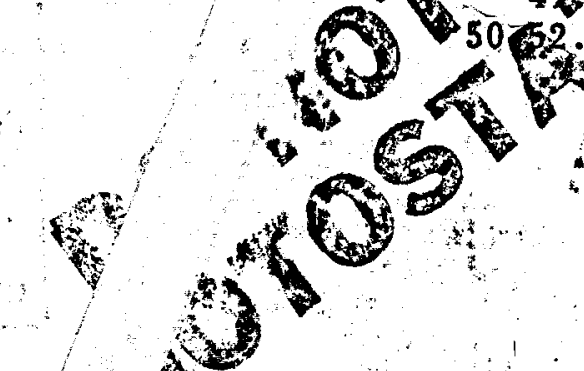

Z. Morgan

S. Felton

A. S. Householder

C. S. Harrill

C. E. Winters

. D. S. Billington

3. D. W. Cardwell

66. E. M. King

37. C. B. Ellis

38. 'D. D. Cowen

39. P. M. Reyling

40. J. H. Frye, Jr.

41. D. E. Hemby

42. J. A. Milko

43. J. H. Erwin

44. J. E. Cunningham

45. W. D. Manly

46. L. K. Jetter

47. J. O. Betterton, Jr.

48. B. S. Borie, Jr.

496 . C. Miller

2. ontraffiles (OP)
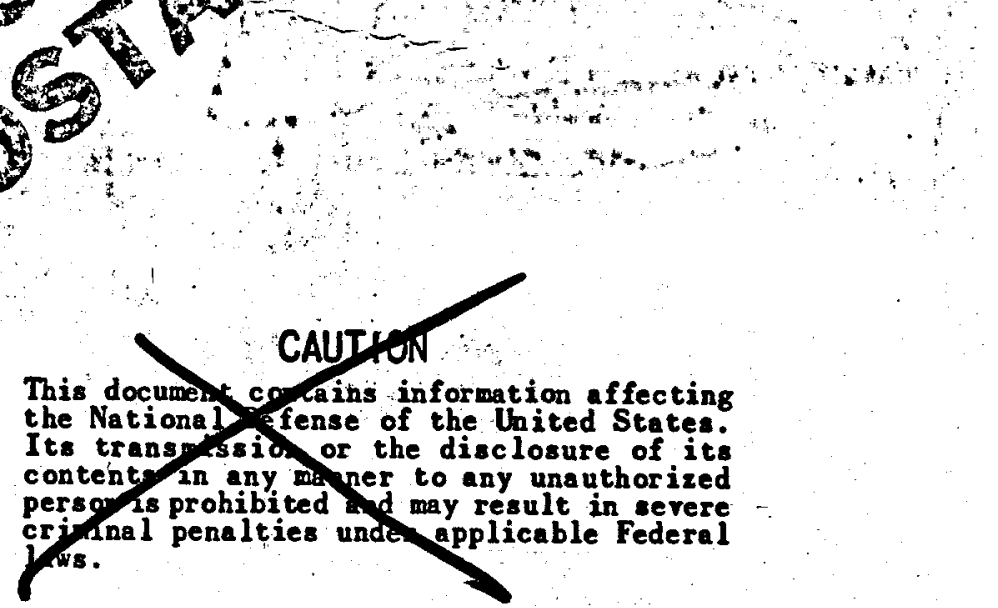


\section{TABLE OF CONTENTS}

\section{EXPERIMENTAL PROCEDURE, RESULTS AND DISCUSSIONS}

Methods of Production of Thorium

Ames Thorium

Iodide Thorium

Westinghouse Thorium

Physical Properties . . . . . . . . . . . . . . . . . . . .

Density

Crystal Structure .....................

Mechanical Properties.....................

Ames and Westinghouse Thorium ................

Tensile Properties . . . . . . . . . . . . . . .

Torsion Testing................. 18-19

Impact Strength . . . . . . . . . . . . . . . 19-21

Iodide Thorium .................... 21-24

Work-Hardening . . . . . . . . . . . . . . . . . . 24-25

Recrystallization . . . . . . . . . . . . . 25-29

Ames Thorium . . . . . . . . . . . . . . . . 25-29

Iodide Thorium....................... . . . . . 29

Thermal Cycling of Ames Thorium in NaK : . . . . . . . . . . 29-36

Fabrication .. . . . . . . . . . . . . . . . . . 36-45

General . . . . . . . . . . . . . . . . 36-38

Extrusion ...................... ... 38-39

Billet Temperature .. . . . . . . . . . . . . 39-43

Extrusion Rate . . . . . . . . . . . . . . . . 43

Reduction Ratio................... 43-44

Lubrication ..................... . . . . . . 44

Die Design . . . . . . . . . . . . . . . . . . . 44

Die and Mandrel Materials ................ . . 44-45

\section{ORESTPHCTED DATA}

This docutint contains restrimed data as defi in the Atomic Energy Act of 1946.

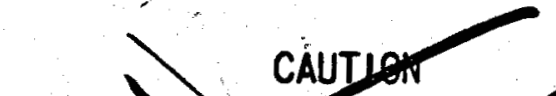

This documet on ans information affecting the National tense of the United States. Its transmission the disclosure of its content. in any manpe to any unauthorized perso is prohibited and maycesult in severe c irinal penaties under applanble Federal 1 axys
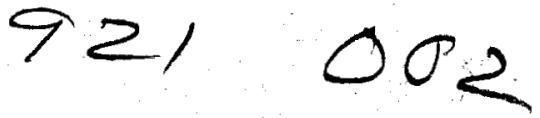


\section{INTER IM REPORT ON METALLURGY OF THORIUM AND THORIUM ALLOYS}

Extrusion Cladding .................... 45-47

Machining . . . . . . . . . . . . . . . . 47-48

Welding . . . . . . . . . . . . . . . . 48-50

Alloy Development ................... 51-72

Melting Procedures................. $51-55$

Testing Procedures . . . . . . . . . . . . . . . 55-56

Alloy Systems ..................... . . . 56

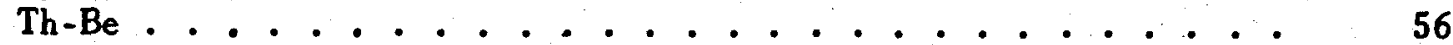

$\mathrm{Th}-\mathrm{Al} . . . . . . . . . . . . . . . . .656-60^{\circ}$

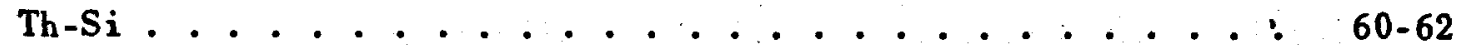

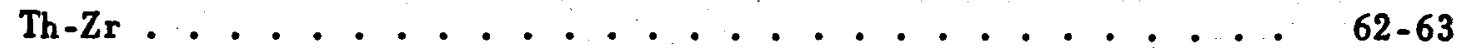

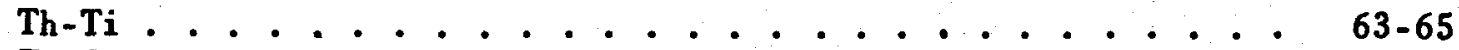

Th-Cr . . . . . . . . . . . . . . . . 65-68

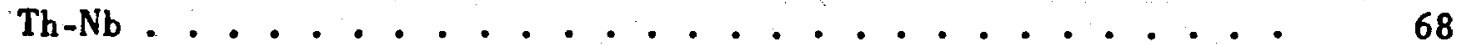

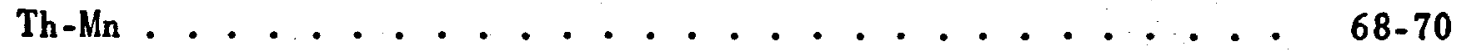

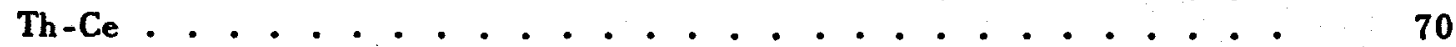

Th-Si-Zr and $\mathrm{Th}-\mathrm{Ti}-\mathrm{Zr}$. . . . . . . . . . . . $70-72$

Corrosion Tests ...................... $72-75$

METALLOGRAPHY OF THORIUM . . . . . . . . . . . . . . . . 76

BIBLIOGRAPHY . . . . . . . . . . . . . . . . . . . . . 77

APPENDIX ............................ $79-81$

vi 


\section{2

\section{LIST OF TABLES}

1 Modulus of Elasticity, Poisson's Ratio, and Shear Modulus of Ames Thorium . . . . . . . . . . . . . . . . . 11

2 Conventional Tensile-Test Data for Ames Thorium . . . . . . . . 14

3: Tensile-Test Data for Extruded Ames Thorium . . . . . . . . 15

4 Vickers and Rockwell Hardness - Ames Compression Test Bars . . . 17

5 Conventional Tensile-Test Data for Westinghouse Thorium . . . . 19

6 Ames Thorium - Conventional Tensile-Test Data for Sheet-Metal Specimen .......................... 21

7 Effect of Strain Rate on Tensile Strength of Ames Thorium . . . 24

8 Shear Modulus of Thorium and Other Materials . . . . . . . . 24

9 Impact Strength of Ames Thorium . . . . . . . . . . . . . 24

10 Tensile Tests on Thorium Welds . . . . . . . . . . . . 50

11 Hardness of Cast Thorium Alloys (All Hardness Values
Rockwell "B" Scale). . . . . . . . . . . . . . . 56

12 Thorium-Aluminum Alloys . . . . . . . . . . . . . 59

13 Thorium Silicon Alloys . . . . . . . . . . . . . . 63

14 Thorium-Zirconium Tensile-Test Data . . . . . . . . . . 63

15 Tensile-Test Data for Annealed Thorium-Chromium Alloys . . . . 68

16 Data for Ternary Thorium Alloys . . . . . . . . . . . . 71

17 Corrosion Data for Thorium and Thorium Alloys in $95^{\circ}$ C
Bistilled Water . . . . . . . . . . . . . . . . 75

\section{APPENOIX}

1 Thermal Cycling of Ames Thorium in NaK between $100^{\circ} \mathrm{C}$

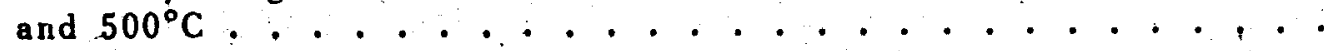




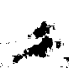

2 


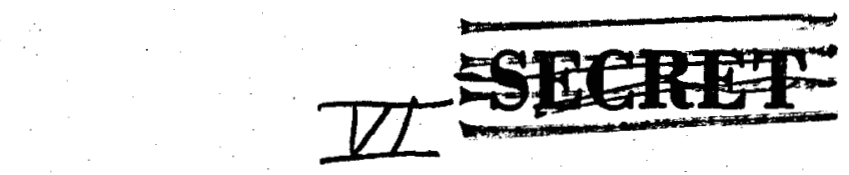

INTER IM REPORT ON METALLURGY OF THORIUM AND THORIUM ALLOYS

\section{LIST OF FIGURES}

Page

1 Ames Thorium Tension and Compression Specimens, Showing the

SR-4, Type A-1 Strain Gages Attached . . . . . . . . . . .

2 Experimental Setup for Determination of Poisson's Ratio Using SR-4 Strain Gages .... . . . . . . . . . . . . . . 9

3 Data for Determination of Modulus of Elasticity . . . . . . . 10

4 Fractured Tensile Specimens of Ames Thorium Annealed $1 / 2 \mathrm{hr}$ at $800^{\circ} \mathrm{C}$ Before Test. . . . . . . . . . . . . .

5. Fractured Ames Thorium Tensile Specimens Annealed $1 / 2 \mathrm{hr}$ at $800^{\circ} \mathrm{C}$ Before Test . . . . . . . . . . . . . . .

6 Stress-Strain Curve for Ames Thorium (Spec. A-180). Coldrolled $35 \%$, Annealed at $750^{\circ} \mathrm{C}$ for $\mathrm{l} \mathrm{hr} \ldots \ldots$. . . . . . 16

7 Stress-Strain Curve for Ames Thorium in Compression Tests ... .

8 Compression Specimen of Ames Thorium . . . . . . . . . . .

9 Stress-Strain Curve for Westinghouse Thorium $1 / 4$ in. Square Bars Annealed at $750^{\circ} \mathrm{C}$ for $1 \mathrm{hr}$. . . . . . . . . . . . .

10 Thorium Tension Test (Ames); Recorder - Full Range; Load Medium Low; Spec. No. 5; Annealed . . . . . . . . . . . .

11. Thorium Tension Test (Ames); Recorder - Full Range; Load Medium Low; Spec. No. 9; Cold-rolled.............. 20

12 Fractured Tensile Specimens of Annealed Ames Thorium . . . . .

13 Fractured Tensile Specimens of Cold-rolled Ames Thorium .....

14 Effect of Elevated Temperature Aging Upon Yield Point in

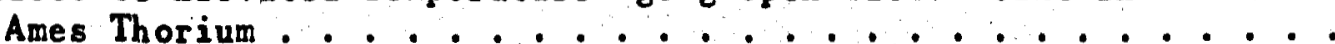

15 Impact Energy for Pure Ames Thorium Standard V-Notch Charpy Specimens . . . . . . . . . . . . . . . . 25

16 Fractured Charpy-Type Impact Specimens of Ames Thorium . . . . 26

17 Iodide Thorium Metal Prepared by the Van Arkel-De Boer Process . . 27 araning 


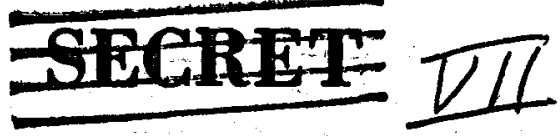

\section{INTERIM REPORT ON METALLURGY OF THORIUM AND THORIUM ALLOYS}

18. Vacuum Arc Furnace . . . . . . . . . . . . . . . . . 28

19 Iodide Thorium Melted in Vacuum Arc Furnace . . . . . . . . 29

20 Photomicrograph of Arc-Melted Iodide Thorium . . . . . . . . . 30

21 Fractured Tensile Specimen of Arc-Melted Iodide Thorium . . . . 30

22 Rate of Work-Hardening of Ames Thorium . . . . . . . . . . 31

23 Work-Hardening Curve for High-Purity Iodide Thorium . . . . . . . 32

24 Recrystallization Curves for Ames Thorium . . . . . . . . . . 33

25 Photomicrographs of Cold-Worked and Heat-Treated Ames Thorium . . 34

26 Isothermal Recrystallization Curves of Ames Thorium . . . . . 35

27 Reciprocal of Absolute Temperature vs Time for Half

Recrystallization in Ames Thorium ................. 36

28 Recrystallization of Iodide Thorium, 80\%. Cold Work . . . . . 36

29. Photomicrographs of Thorium Specimens Prior to Cycling . . . . 37

30 Disassembled Parts of Container for Thermal Cycling of

Thorium in NaK ...................... 38

31 Experimental Setup for Cycling Samples in NaK . . . . . . . 38

32. Thorium Bars After 1000 Cycles . . . . . . . . . . . . 39

33a Ames Thorium Extruded, Cold-Rolled, Annealed $1 / 2 \mathrm{hr}$ at $750^{\circ} \mathrm{C}$, Cycled for 1000 Cycles Between $100^{\circ} \mathrm{C}$ and $500^{\circ} \mathrm{C}$ in $\mathrm{NaK}$. . . 40

33b Ames Thorium Extruded at $850^{\circ} \mathrm{C}$ and Cycled for 1000 Cycles

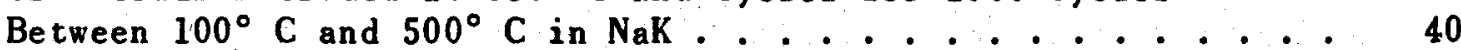

33c Ames Thorium Extruded into 3/4-in.-dia Rod at $825^{\circ} \mathrm{C}$, Cold-swaged to $1 / 2$-in.-dia Rod, and Thermally Cycled for 1000 Cycles

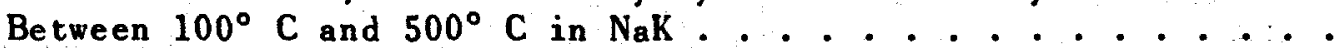

33d Ames Thorium Extruded into $\%$-in.-dia Rod at $825^{\circ} \mathrm{C}$, Cold-rolled

to $1 / 2$-in.-dia Rod, and Thermally Cycled for 1000 Cycles

Between $100^{\circ} \mathrm{C}$ and $500^{\circ} \mathrm{C}$ in $\mathrm{NaK} \ldots \ldots . . . \ldots . . . . . . . .41$

34. 700-Ton Lake Erie Extrusion Press . . . . . . . . . . . . 42 


\section{SEARER}

INTER IM REPORT ON METALLURGY OF THORIUM AND THORIUM ALLOYS

Page

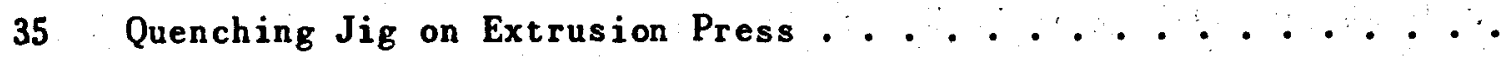

43

36 " Billet of Ames Thorium Prepared for Tubing Extrusion . . . . . .

43

37 Tubing Extruded from Ames Thorium . . . . . . . . . . . . .

38 Partially Extruded Thorium Billet in Section . . . . . . . . . 45

39 Sectional Views of Duplex Th-Zr Tube Produced by Extrusion . . . . 46

40 Sectional Views of Trailing End of Extruded Thorium Tube with Zirconium Lining ................... . 47

41 Th-Zr Interface of Extruded Th Tube Clad on Inside with Zr . . . 48

42 Interface of $T h-Z_{r}$ in Extruded.Tube . . . . . . . . . . . . 49

43 Broken Tensile Specimens of Welded Ames Thorium $\ldots \ldots \ldots$

44. Hardness Traverses of Thorium Welds . . . . . . . . . . . 51

45 Photomicrograph of Welded Ames Thorium Specimens $\ldots \ldots$

46 Schematic Diagram of Silica-Tube Vacuum Furnace for

Melting Thorium . . . . . . . . . . . . . . . .

47 Tilting Vacuum Furnace . . . . . . . . . . . . . . . . 54

48 Photomicrographs of Ames Thorium Before and After Melting in $\mathrm{ZrO}_{2}$. 55

49 Photomicrographs of Th-Be Alloys . . . . . . . ..$^{-57-58}$

50 Photomicrographs of Th-Al Alloys . . . . . . . . . . . . . 59

51 Photomicrographs of Th-Al Alloys Showing Progress of Corrosion • 61

52 Photomicrographs of Th-Si Alloys $\ldots \ldots 2$

53 Load-Elongation Curve for $2 \% \mathrm{Zr}-\mathrm{Th}$ Alloy . . . . . . . . 64

54 Photomicrographs of Th-Zr Alloys . . . . . . . . . . 65

55 Photomicrographs of Th-Ti Alloys _.............. 66

56 Load-Elongation Curve for $2 \% \mathrm{Ti}-\mathrm{Th}$ Alloy $\ldots . . . \ldots 7$

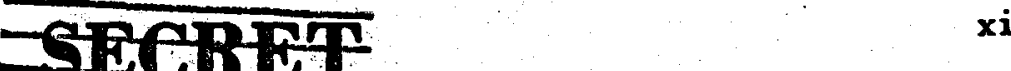

921 607 
INTER IM REPORT ON METALLURGY OF THOR IUM AND THORIUM ALLOYS

\section{Page}

57 Photomicrographs of Th-Cr Alloys . . . . . . . . . . . . . 67

58 Photomicrographs of Th-Nb Alloys . . . . . . . . . . . . 69

59 Photomicrographs of Th-Mn Alloys . . . . . . . . . . . . . 69

60 Photomicrographs of Th-Ce Alloys . . . . . . . . . . . . 70

61 Photomicrographs of Ternary Alloys of Thorium . . . . . . 73-74 


\section{INTER IM REPORT ON METALLURGY OF THORIUM AND THORIUM ALLOYS \\ ABSTRACT ORNL 1090}

\begin{abstract}
A COMPREHENSIVE study has been made of the physical metallurgy of thoritm and some of its alloys. Mechanical properties such as tensile strength, ductility, modulus of elasticity, Poisson's ratio, shear modulus, and impact strength have been determined for Ames, thorium. A few tests were made on iodide thórium and Westinghouse thorium.
\end{abstract}

Density determinations have been made on Ames, iodide, and Westinghouse thorium samples. Precision measurements of the lattice parameters of iodide thorium were made by $X-r a y$ diffraction.

Work-hardening characteristics and recrystallization temperatures have been established for both Ames and iodide thórium.
The fabricating characteristics of thorium have been studied by rolling, swaging, extrusion, forging, and welding. Cladding of thorium with irconium was accomplished by extrusion.

Thermal cycling of thorium has been carried out in $\mathrm{NaK}$ at temperatures of $100^{\circ} \mathrm{C}$ to $500^{\circ} \mathrm{C}$ to investigate dimensional stability.

A preliminary investigation has been made of binary thorium alloys containing additions of $\mathrm{Be}, \mathrm{Si}, \mathrm{Zr}$, $\mathrm{Ti}, \mathrm{Al}, \mathrm{Nb}, \mathrm{Cr}, \mathrm{Mn}$, and $\mathrm{Ce}$. Melting range, fabricating characteristics, hardness, and tensile properties were studied. Ternary alloys containing $\mathrm{Zr}-\mathrm{Ti}$ and $\mathrm{Zr}-\mathrm{Si}$ were investigated in like manner.

Corrosion tests in water at $95^{\circ} \mathrm{C}$ were carried out on Ames thorium and all of the alloys under study.

\subsection{9}




\section{INTER IM REPORT ON METALLURGY OF THORIUM AND THORIUM ALLOYS}

\section{INTRODUCTION}

\begin{abstract}
A PROGRAM of thorium research was Aundertaken by the Metallurgy Division of ORNL in July 1949 after a literature survey revealed that very little work was being done with thorium and little data were available except those contained in progress reports from Ames Laboratory. It was felt that a broad research program was needed to insure a complete knowledge of the properties of the metal for future applications. One of the principal anticipated uses for thorium is for the production of $\mathrm{U}^{233}$. The fertile isotope $T^{232}$ may be used to produce the fissionable $U^{233}$ in a "breeder" pile according to the following reactions:
\end{abstract}

$$
\begin{aligned}
& { }_{90} \operatorname{Th}^{232}+{ }_{0} \mathrm{n}^{1} \longrightarrow{ }_{90} \operatorname{Th}^{233}+\gamma \\
& { }_{90} \mathrm{Th}^{233} \underset{23 \mathrm{~m} .}{\stackrel{\beta^{-}}{\longrightarrow}} 9 \mathrm{~Pa}^{233} \underset{27.4 \mathrm{~d} .}{\stackrel{\beta^{-}}{\longrightarrow}} 9_{2} \mathrm{U}^{233}
\end{aligned}
$$

Such use of the metaliic thorium would require a knowledge of the properties of the material and fabrication techniques to permit the most efficient use of the metal.
The planned program was composed of four phases: (1) A study of the properties of pure metal, (2) an alloy development program, (3) an investigation of fabrication techniques, and (4) radiation-damage work. Since very little data were available for mechanical properties of thorium and thorium alloys, the first two phases were undertaken initially, and plans were made for extension of the work at a later date when sufficient material became available. The two latter phases have been initiated only recently, and will be continued concurrently with the other work for a more complete investigation.

The metal used for the most of the work was prepared by the Ames Laboratory, at Iowa State College, Ames, Iowa, by the calcium reduction of thorium tetrafluoride. High-purity thorium prepared by the thermal decomposition of thorium tetraiodide on a hot filament was tested to evaluate the effect of impurities in the metal. Westinghouse thorium, which had been prepared by compacting the powdered metal, was tested and compared with the Ames metal.

\section{010}




\section{CONCLUSIONS}

THE current methods for production 1 of thorium metal are reviewed to identify the metals used in the investigation. The three types of metal used were Ames calcium-reduced thorium, Westinghouse powder-compacted thorium, and thorium produced by the thermal decomposition of thorium tetraiodide. The high-purity iodide thorium is much softer than Ames or Westinghouse thorium.

The mechanical properties of each type of thorium were determined at room temperature. Specimens were tested in tension, compression, and torsion. Poisson's ratio and modulus of elasticity both in tension and compression were determined using SR-4 strain gauges. The values obtained for Poisson's ratio and modulus of elasticity were 0.265 and $10 \times 10^{6} \mathrm{re}-$ spectively. The shear modulus was calculated from tensile data as 4.06 and also determined experimentally in torsion as $4.25 \times 10^{\circ}$. A yield point was shown in the load-elongation curve of Ames thorium similar to that found in the case of low carbon steels. It wes found that the addition of $2 \% \mathrm{Ti}$ to thorium removed this yield point. High-purity iodide thorium did not show a yield point in the load-elongation curve. Impact testing of V-notch Charpy-type specimens showed that Ames thorium exhibits transition from brittle to tough behavior over a relatively narrow temperature range, $120^{\circ} \mathrm{C}$ to $200^{\circ} \mathrm{C}$.

Density measurements were made on Ames thorium and iodide thorium by comparing weights of samples weighed in water against those for air. The values ranged from 11.6324 to 11.6435 g/cc for Ames and from 11.4903 to 11:7550 for iodide material. These compare with a value of 11.7100 as calculated from precision latice parameter measurement of $5.0871 \pm$ $0.0002 \mathrm{~A}$ at $26.5^{\circ} \mathrm{C}$ determined by $X-r a y$ diffaction,

Thorium, regardless of the method of preparation, was found to workharden very rapidly when subjected to cold-working. However, the magnitude of the work-hardening is relatively small, so that thorium may be coldworked to extremely high reductions without an intermediate anneal. Thus, thorium may be fabricated readily by rolling. forging, swaging, or extrusion. Recrystallization studies on Ames thorium and iodide thorium indicate that the recrystallization range for heavily worked metal is $535^{\circ} \mathrm{C}$ to $650^{\circ} \mathrm{C}$ with the higher purity, iodide thorium requiring the higher temperatures. Ames thorium has been extruded into various shapes such as rods, tubes, and flat bars. Investigation of the extrusion variables revealed that extrusion rate, reduction ratio, and extrusion temperature had very little effect on the finished extrusion. The most serious problem encountered in the extrusion of thorium was that of die materials to withstand the erosive action of the flowing metal. Duplex extrusions to produce thorium tube with cladding of zirconium have been made in which a satisfactory bond between the two metals was obtained.

Preliminary experiments on welding of thorium indicate that welding can probably be performed using standard heliarc techniques in a protective atmosphere. Thorium welds tend to 


\section{INTERIM REPORT ON METALLURGY OF THOR IUM AND THORIUM ALLOYS}

crack if made while the metal is under restraint, indicating that thorium may be hot short. Also, thorium was welded to zirconium using no more than ordinary precautions to avoid oxidation.

Machining of thorium presents no particular difficulty, since it is comparable to mild steel in this respect. Clean thorium metal when machined with a coolant presents np oxidation or fire hazard.

Metallographic techniques for thorium require special care to avoid misinterpretation of the microstructure. The most commonly used etch is $50 \%$ glacial acetic acid and $50 \%$ or thophosphoric acid. However, a more satisfactory etch for showing the grain boundaries was found to be an electrolytic etch in a solution consisting of 1 part perchloric acid and 10 parts acetic acid.

Thorium bars were temperature-cycled between $100^{\circ} \mathrm{C}$ and $500^{\circ} \mathrm{C}$ in eutectic NaK to determine the dimensional stability and corrosion resistance. Thorium was oxidized somewhat because of its scavenging action on the $\mathrm{NaK}$. There was no evidence of growth, but some distortion was found in extruded and swaged samples, apparently due to unequal residual stress in the worked metal.

A thorium alloy development program was carried out to investigate thoriumrich alloys. Alloys were prepared with various metals on the basis of their good nuclear properties or with metals calculated to improve the properties of thorium. It was found that a number of alloys were softer than the original thorium, notably alloys of $T i, Z_{r}$, and $\mathrm{Nb}$. Other alloys had a higher hardness and also showed a much higher tensile strength than pure thorium. One of the most interesting alloys was the $2 \% \mathrm{Cr}-\mathrm{Th}$ alloy, which had tensile strengths almost twice as high as unalloyed thorium.

Aqueous corrosion tests were made to evaluate the thorium and thorium alloys. In general, the corrosion resistance of the pure metal and its alloys has been poor in $95^{\circ} \mathrm{C}$ water tests. 


\section{EXPERIMENTAL PROCEDURE, RESULTS; AND DISCUSSIONS}

\section{Hethods OF PRODUCtion OF THORIUM}

Since three different types of thorium metal are used in the present investigation, a brief review of the methods of producing thorium will be given as an indication of the past histories of the various metals. The majority of the thorium being produced at the present time is made at Ames Laboratory, Iowa State College, and will be referred to as Ames thorium. Small amounts of high-purity thorium have been preparedat Battelle Memorial Institute by the thermal decomposition of thorium tetraiodide and will be designated as iodide thorium. Some metal has been prepared by sintering compacted powdered metal. Since the powder-compacted metal is a Westinghouse product, this will be called Westinghouse thorium.

Ames Thorium - The Ames Process(1) uses as a starting material purified thorium nitrate, $\mathrm{ThNO}_{3} \cdot 4 \mathrm{H}_{2} \mathrm{O}$, which is prepared from monazite sand. The nitrate is treated with oxalic acid and calcined to $\mathrm{ThO}_{2}$. A hydrofluorination step converts the thorium oxide to thorium tetrafluoride, which is mixed with calcium and $z$ inc chloride and charged into a steel bomb $5 \times 40$ in. The bomb is lined with a high-burned, high-calcium lime or electrically fused dolomitic oxide. The bomb is placed in a gas-fired furnace at $1050^{\circ} \mathrm{F}$ to $1100^{\circ}$ F and the reaction is completed in 20-25 min. The zinc chloride acts as a booster and also serves to form a low-melting alloy (about $8 \%, Z_{n}$ ) with the reduced thorium and consolidate the metal. The Th- $Z_{n}$ alloy is separated from the $\mathrm{CaF}_{2}-\mathrm{CaCl}_{2}$ slag and dezinded by heating to $1100^{\circ} \mathrm{C}$ in a vacum induction furnace: The zinc is distilled of rapidly, leaving a spongy residue of thorium metal with less than $1 \%$ residual $\mathrm{Zn}$. The metal becomes plastic but does not melt. The thorium is remelted in vacuum induction furnace using a $\mathrm{BeO}$ crucible inside a graphite heater. The metal is melted and heated to $1850^{\circ}-1900^{\circ} \mathrm{C}$ and cast into graphite molds. The ingots are scalped to remove surface defects and any thorium carbide which may have been formed. Ames thorium contains some impurities derived from the process of preparation. Approximately $0.031 \%$ beryllium and $0.05 \% \mathrm{O}_{2}$ are present because of some reduction of the $\mathrm{BeO}$ crucible. About $0.07 \%$ to $0.2 \%$ carbon is picked up from the graphite mold or powdered carbon insulation. Other impurities present in trace amounts are $\mathrm{Fe}, \mathrm{Al}, \mathrm{Ca}, \mathrm{N}_{2}$. $\mathrm{Si}$, and $\mathrm{Mn}$.

Iodide Thorium - High-purity thorium has been prepared at Battelle Memorial Institute by the Van Arke 1-DeBoer process. The thorium is deposited on a hot filament wire by decomposition of thorium tetraiodide. The method of producing the deposited metal is as follows: Chips of crude thorium (Ames) are placed in the annulus formed when a cylindrical screen of molybdenum is placed inside a Pyrex glass tube. The top part of the tube contains two electrodes to which are attached the ends of the starting filament. Some metal was produced using $0.003-M-d i a m-$ eter wolfram wire as a filament. Later, thorium wire was substituted for the wolfram in order to produce a higherpurity product. However, this gave rise to problems of burning out the filament wire before deposition was 


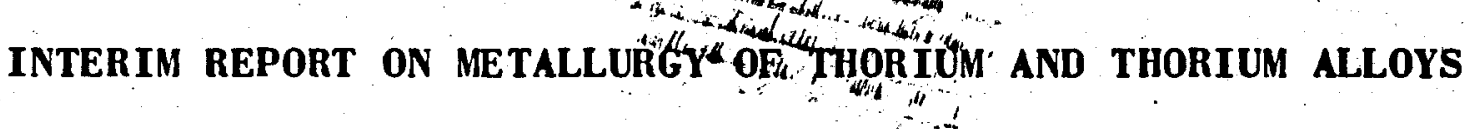

complete. When thorium wire is used, it is necessary to start with wire $1 / 16$ in. in diameter. The closed-end tube is placed in a furnace and heated to $750^{\circ} \mathrm{C}$ with an auxiliary heater to maintain a temperature of $800^{\circ} \mathrm{C}$ at the top of the tube. The tube is then evacuated and sealed of $f$ wile under vacuum. Iodine is sublimed into the main reaction tube where it reacts with the crude thorium to form thorium tetraiodide according to the following reaction:

$$
\mathrm{Th}+2 \mathrm{I}_{2} \longrightarrow \mathrm{ThI}_{4}
$$

The filament is heated to approximately $1100^{\circ} \mathrm{C}$ by applying power at a low voltage and high current and the thorium tetraiodide is reduced to deposit metallic thorium and liberate free iodine which again reacts with the feed material.

After a deposit is made, the temperature of the filament is increased to make a more coherent bar. The originally deposited crystals are very loosely coherent and the bar is very fragile. Spectrographic analysis shows the metal to be pure except for a trace of calcium. Chemical analysis shows $0.0002 \% \mathrm{H}_{2}, 0.05 \% \mathrm{C}, 0.012 \% \mathrm{O}_{2}$.

Westinghouse Thorium - The starting material for Westinghouse thorium is thorium oxide. (2) The oxide is reduced with calcium, the reduction being carried out in a steel crucible in a steel bomb. The crucible is lined with molybdenum so the calcium will not react with the steel at high temperatures.

The charge is thoria with an excess of $100 \%$ calcium placed in alternate layers in the crucible. The bomb assembly, with an argon atmosphere, is placed in a furnace at $1200^{\circ} \mathrm{C}$. When the reaction is complete, the bomb is slow-cooled and not opened until the temperature falls below $100^{\circ} \mathrm{C}$ because of the high reactivity of thorium with oxygen.

The charge and crucible are placed in a leaching tank of cold water and glacial acetic acid equivalent to the total amount of calcium charged. The powder isfiltered, washed with alcohol, and vacuum dried. The powder is then compacted at pressures varying from 2-10 tons per square inch. The bars are slowly heated to $1450^{\circ} \mathrm{C}$ in vacuum and sintered at temperature for 30 $\min$.

\section{PHYSICAL PROPERTIES}

Density - The density of various samples of thorium have been determined by immersion. The sampleswereweighed in carbon tetrachloride or water and then weighed in air, the difference in weight being the weight of an equal volume of the liquid. Letting $M a=$ weight in air and $M f=$ weight in fluid, we have the relation $M a-M f=M \omega$ (weight of equal volume of liquid). Thus, the relative density is

$$
\frac{M a}{M a-M_{f}}
$$

The values for the density of the fluid at the testing temperature were obtained and the density of thorium calculated in $\mathrm{gm} / \mathrm{cc}$. The average experimental values were as follows:
Ames as-cast
$11.6324 \mathrm{~g} / \mathrm{cc}$
Ames rolled
$11.6381 \mathrm{~g} / \mathrm{cc}$
Ames extruded
$11.6435 \mathrm{~g} / \mathrm{cc}$
Iodide as deposited
$11.4903 \mathrm{~g} / \mathrm{cc}$
Iodide arc-melted 


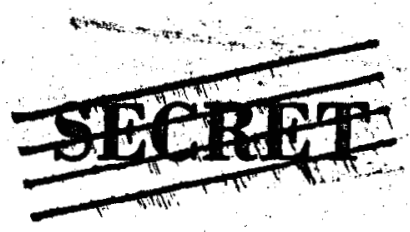

\section{INTERIM REPORT ON METALLURGY OF THORIUM AND THORIUM ALLOYS}

Iodide arc-melted and rolled

$$
\begin{aligned}
& 11.7550 \mathrm{~g} / \mathrm{cc} \\
& 10.3540 \mathrm{~g} / \mathrm{cc}
\end{aligned}
$$

Westinghouse sintered bar

The theoretical density as calculated from X-ray measurements of lattice parameter of iodide thorium is $11,7100 \mathrm{gm} / \mathrm{cc}$.

Crystal structure - Thorium is face-centered cubic with a lattice parameter of $5.0871 \pm 0.0002$ A at a temperature of $26.2^{\circ}$ C. A precision lattice-parameter measurement was made using iodide thorium which had been arc-melted and rolled into sheet. The sheet was vacuum-annealed and powder prepared by filing. The filings were passed through a 100 -mesh screen and then annealed for $1 / 2$ hr at $750^{\circ} \mathrm{C}$ and furnace-cooled. A. Debye-Scherrer needle was prepared with Duco cement and the diffraction pattern recorded with a $114.6 \mathrm{~mm}$ North American Phillips camera. Room temperature during the exposure was recorded at the camera with a mercury thermometer. Copper $K$ alpha radiation: $\left(\lambda a_{1}=1.54050 \mathrm{~A}\right.$, $\lambda a_{2}=1.54434$ A) filtered through nickel foil was used.

The alpha doublet was observed to be resolved for the $440,531,600$, 620 , and 533 lines. The values for $2 \theta$ for these lines were measured with a traveling microscope and corrected far film shrinkage. These data were used to make a graphical extrapolation by the method of Bradley and Jay (3) The lattice parameter was determined at $5.0871 \pm 0.0002 \mathrm{~A}$ at $26.2^{\circ} \mathrm{C}$.

\section{mechanical Properties}

\section{Ames and Westinghouse Thorium}

Tensile Properties - The first lot of thorium metal to become arailable was scrap material from metal used to prepare bars for irradiation tests at Hanford. This metal was cast at Ames Laboratory, forged at Battelle Memorial Institute, rolled and machined at Westinghouse. A typical analysis of this material was as follows:

$$
\begin{aligned}
& 0.07 \% \mathrm{C}, 0.15 \% \mathrm{O}_{2}, 0.07 \% \mathrm{~N}_{2}, \text { and } \\
& \text { traces of } \mathrm{Ca}, \mathrm{Fe}_{,} \mathrm{Si}, \text { and } \mathrm{Mg} \text {. }
\end{aligned}
$$

At Oak Ridge National Laboratory, the rods were annealed for $\mathrm{l} \mathrm{hr}$ at $750^{\circ} \mathrm{C}$ and rolled from 1-1/4-in diameter to 13/16-in diameter with a reduction of 0.020 in per pass. Samples from this rolled stock were used for preferred orientation studies. It was found that there existed a poorly developed 210 fiber texture and a 111 fiber texture even less developed: The average re crystallized grain size of the tensile bars was found to be 0.04 to $0.05 \mathrm{~mm}$.

The rolled bars of Ames thorium were machined into tension and compression bars. After the test bars were machined, they were annealed at $800^{\circ} \mathrm{C}$ for $1 / 2 h r$, polished, and four type A-1 SR-4 strain gages were applied.: The four strain gages were placed on the specimen so two gages would read the longitudinal strain and two gages the lateral strain. The specimens with gages attached are shown in Fig. 1 . All precautions for the application of strain gages were followed to insure proper operation.*

The specimens were tested in a 120,000-1b Baldwin Southwark tensiletesting machine. The experimental setup is shown in Fig. 2. Lateral

- Credit is due Mr. Warren Brand of Instrument Division of Oak Ridge National Laboratory for his assistance in making the experimental setup for using SR-4 strain gages. 


\section{INTER IM REPORT ON METALLURGY OF THORIUM AND THORIUM ALLOYS}

\section{UNCLASSIFIED}

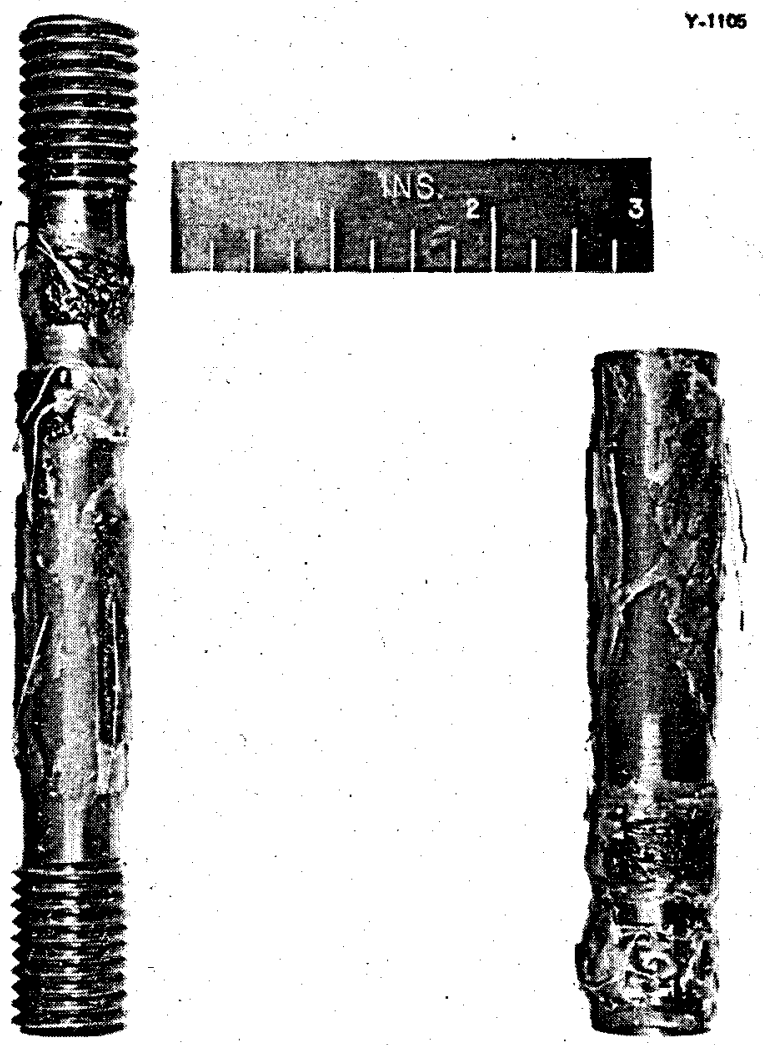

Fig. 1 - Ames Thorium Tension and Compression specimens, Showing the SR-4, Type A-1 Strain Gages At tached.

strain measurements were made with an SR-4 Wheatstone Bridge Control Box; longitudinal strain measurements were made with an SR-4 Type K Portable Strain Indicator.

After zero-load readings were recorded for all four gages, the specimen was loaded to $100 \mathrm{lb}$, the load was released, and zero readings were checked. The specimen was then loaded at intervals of $200 \mathrm{lb}$ up to $1000 \mathrm{lb}$; above $1000 \mathrm{lb}$, the intervals were increased to $250 \mathrm{lb}$. After each increment of loading, all four strain gages were read and recorded with the load at that interval. The error in reading the load was \pm 1 lb up to a $1000-1 b$ load and $\pm 5 \mathrm{lb}$ above the $1000-1 \mathrm{~b}$ load. The error in strain measurement was $\pm 10 \times 10^{-6}$ in per in.

Load-elongation curves were plotted from the values of stress and strain determined in these tests. The values of longitudinal strain obtained from both gages and the average strain were plotted at the different stress values. The curve of the average longitudinal strain plotted as a fuction of stress gives good straight line from which the modulus of elasticity could be calculated. A typical stress-strain curve plotted from the data obtained from the two strain gages reading axial strain is shown in Fig. 3 .

Poisson's ratio was calculated at each stress level by dividing the average transverse strain by the arerage longitudinal strain. The values at the different stress levels were averaged for the value of Poisson's ratio for the individual specimens.

The shear modulus was calculated from the interrelationship of Poisson's ratio and modulus of elasticity.

$$
G=\frac{E}{2(1+U)}
$$

where $\quad G=$ shear modulus

$$
\begin{aligned}
& E=\text { modulus of elasticity } \\
& U=\text { Poisson's ratio }
\end{aligned}
$$

Three values of shear modulus were calculated, one from the average tensile test data, one from average compression test data, and one from the 


\section{INTERIM REPORT ON METALLURGY OF THORIUM AND THORIUM ALLOYS}

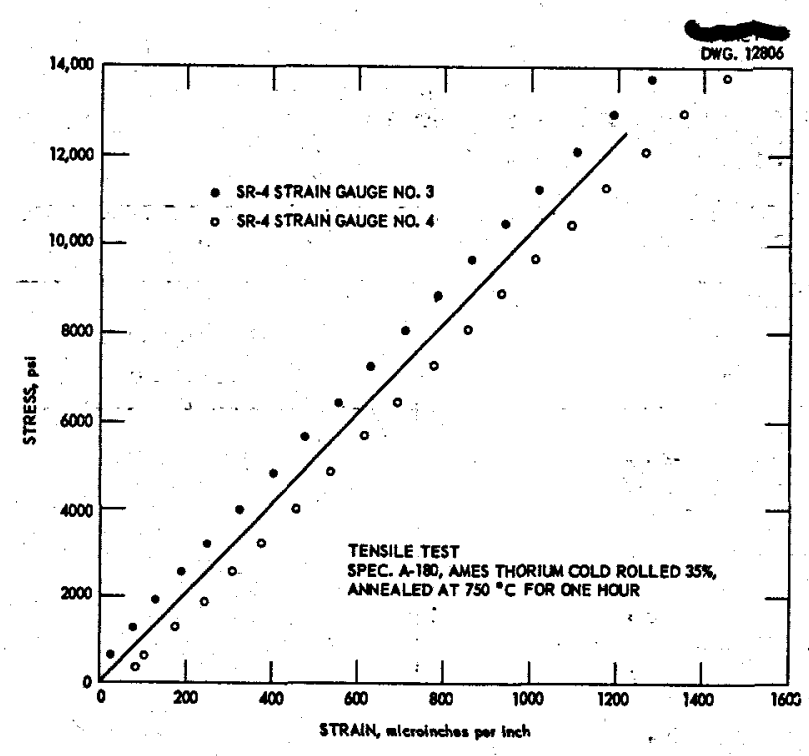

Fig. 3 - Data for Determination of Modulus of Elasticity.

tests compared favorably with that obtained by the use of SR-4 strain gages.

A second set of tensile specimens was prepared from Ames thorium extruded into rods at Oak Ridge National Laboratory. The thorium was obtained in ingot form from Ames Laboratory and cut into extrusion billets measuring 3 in. in diameter and approximately 6 in. long.

The rods were extruded during an investigation of extrusion variables so that rods were prepared under different conditions of temperature, reduction ratio, and rate of extrusion. The specimens were pulled to determine the effect of extrusion variables upon the tensile properties of the Ames thorium, but no correlation was found. However, the tensile strength of the specimens could be related to the original ingot numbers, indicating a composition effect

The static tensile properties along with available analytical data are shown in Table 3 .

It may be seen that the tensile strength may be directly correlated to the carbon content. The series of tensile bars could be grouped according to carbon content as follows: low carbon (approximately $0.05 \%$ ), medium carbon. $(0.07 \%)$, and high carbon (0.09\%). A corresponding grouping of tensile strength would show average values of 30,000 psi, 35,000 psi, and 38,000 psi for the low, medium, and high carbon contents respectively.

Yield Point - A typical load-elongation curve from a tensile test of Ames Thorium is given in Fig. 6: This curve has a pronounced "yield point" comparable to yield points seen in load-elongation curves of low-carbon steel. Compression tests on thorium also show this yield point (Fig. 7). Bars of Ames thorium, 3/4 in. in diameter by $2 \frac{1}{2}$ in. long were compressed to a maximum load of 100,000 lb without breaking or cracking. This represented a total change in length of approximately $80 \%$. The average Rockwell and Vickers hardness of each compression sample was taken in the part of the specimen corresponding to the original cross-section. The compressed specimen with indentations from hardness measurements is shown in Fig. 8 where the original diameter is still visible. The hardness was determined also from the edge of the original cross-section to the outside of the compressed specimen. The values of average hardness and the variation of hardness from the center to the edge of the specimen are given in Table 4.

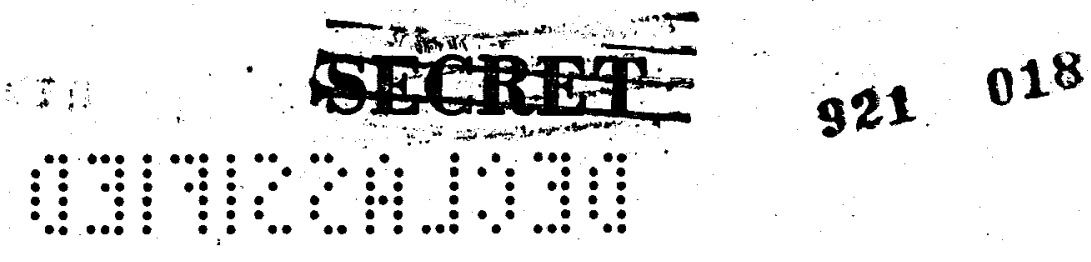




\section{INTERIM REPORT ON METALLURGY OF THOR IUM AND THORIUM ALLOYS}

TABLE 1

Modulus of Elasticity, Poisson's Ratio, and Shear Modulus of Ames Thorium

\begin{tabular}{|c|c|c|c|}
\hline \multicolumn{4}{|c|}{ Tension Test } \\
\hline Specimen No. & $\begin{array}{l}\text { Modulus of } \\
\text { Elasticity }\end{array}$ & Poisson's Ratio & $\begin{array}{l}\text { Shear Modulus } \\
\text { (Calculated) }\end{array}$ \\
\hline$A-164$ & $10.0 \times 10^{6}$ & .294 & \\
\hline$A-166$ & $9.9 \times 10^{6}$ & .247 & \\
\hline$A-180$ & $10.4 \times 10^{6}$ & .262 & \\
\hline$A-183$ & $9.92 \times 10^{6}$ & .263 & \\
\hline A. 174 & $10.16 \times 10^{6}$ & .287 & \\
\hline A-179 & $10.44 \times 10^{6}$ & .241 & \\
\hline Average & $10.13 \times 10^{6}$ & .265 & $4.00 \times 10^{6}$ \\
\hline \multicolumn{4}{|c|}{ Compression Test } \\
\hline$A-155$ & $11.1 \times 10^{\circ}$ & .210 & \\
\hline$A-164$ & $10.16 \times 10^{6}$ & .210 & \\
\hline$A-164$ & $10.16 \times 10^{6}$ & .261 & \\
\hline$A-166$ & $10.10 \times 10^{6}$ & .344 & \\
\hline$A-180$ & $10.6 \times 10^{6}$ & .267 & \\
\hline Average & $10.49 \times 10^{6}$ & .270 & $4.12 \times 10^{6}$ \\
\hline Over-a 11 Average & $10.31 \times 10^{6}$ & .268 & $4.06 \times 10^{6}$ \\
\hline
\end{tabular}

Tensile tests on Westinghouse thorium, both in the as-received and in the annealed condition, gave a yield point in the load-elongation curve. A typical load-elongation curve for West inghouse thorium is shown in Fig. 9. The conventional tensile-test data for the powder compact thorium, Table 5 , show that this material has less ductility and strength than the Ames thorium.

Experimenters have found that coldwork will remove the yield point of low-carbon steels, but the yield point will return if there is a time delay between cold-working and testing. In order to investigate this possibility in the case of thorium, conventional sheet-metal-type specimens were machined from 1/4-in. Ames thorium plate for testing. After machining, the specimens were annealed at $750^{\circ} \mathrm{C}$ for $1 / 2 \mathrm{hr}$ in a vacuum furnace. Five specimens were pulled in tension in the annealed condition. The yield point may be seen in the load-elongation curve of a typical annealed specimen shown

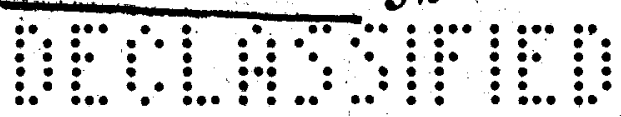




\section{INTER IM REPORT ON METALLURGY OF THORIUM AND THORIUM ALLOYS}

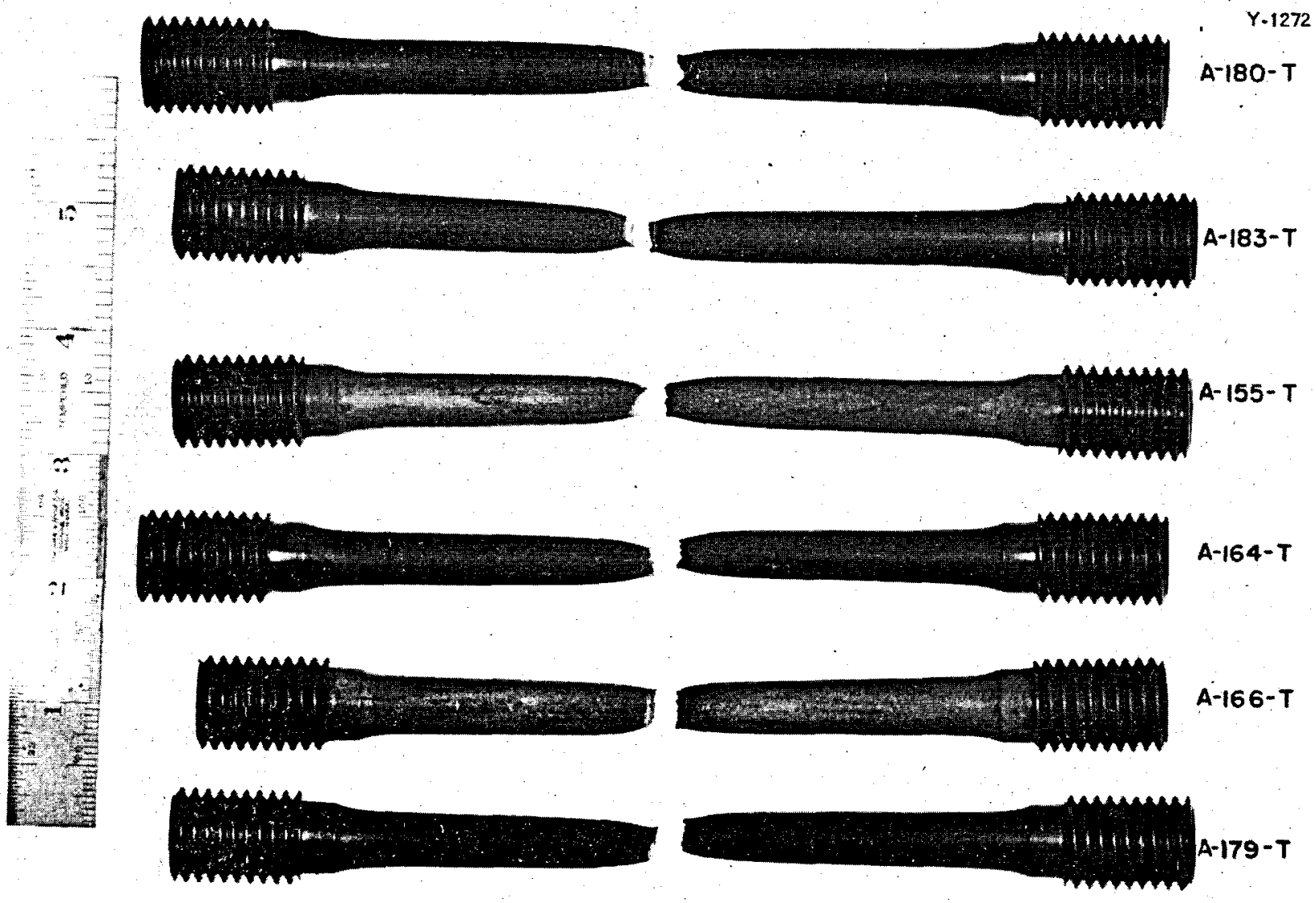

Fig. 4 - Fractured Tensile Specimens of Ames Thorium Annealed $/ 2$ hr at $800^{\circ} \mathrm{C}$ Before Test.

in Fig. 10. Other specimens were reduced in thickness $5 \%$ by cold-rolling prior to the tensile test, and the loadelongation curves of these cold-worked specimens did not show the yield point of thorium (Fig. 11). The conventional tensile-test data obtained from these tests are presented in Table 6. Photographs of typical fractures of these bars are shown in Figs. 12 and 13 . Additional tensile specimens which had been cold-worked were aged at various temperatures for various lengths of time to see what aging treatment is necessary to cause the yield point to return. Room-temperature aging was checked at approximately $360-\mathrm{hr}$ intervals for a yield point. However, the specimen which was aged for the maximum time of $2016 \mathrm{hr}$ did not show a yield point, and room-temperature aging was discontinued in favor of shorttime aging treatments at higher temperatures.' Specimens were heated for $1 \mathrm{hr}$ at each of the following temperatures: $100^{\circ} \mathrm{C}, 200^{\circ} \mathrm{C}, 300^{\circ} \mathrm{C}, 400^{\circ} \mathrm{C}$, $500^{\circ} \mathrm{C}, 600^{\circ} \mathrm{C}$, and $750^{\circ} \mathrm{C}$. The samples were pulled in tension at room temperature immediately after the elevated-temperature aging. Adefinite

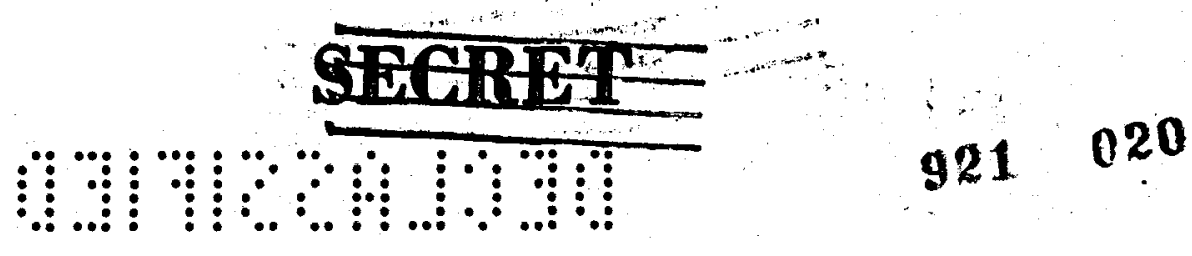




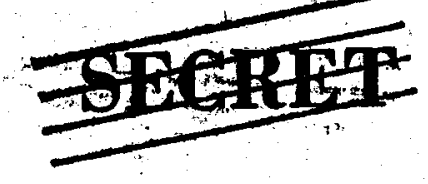

INTER IM REPORT ON METALLURGY OF THOR IUM AND THORIUM ALLOYS
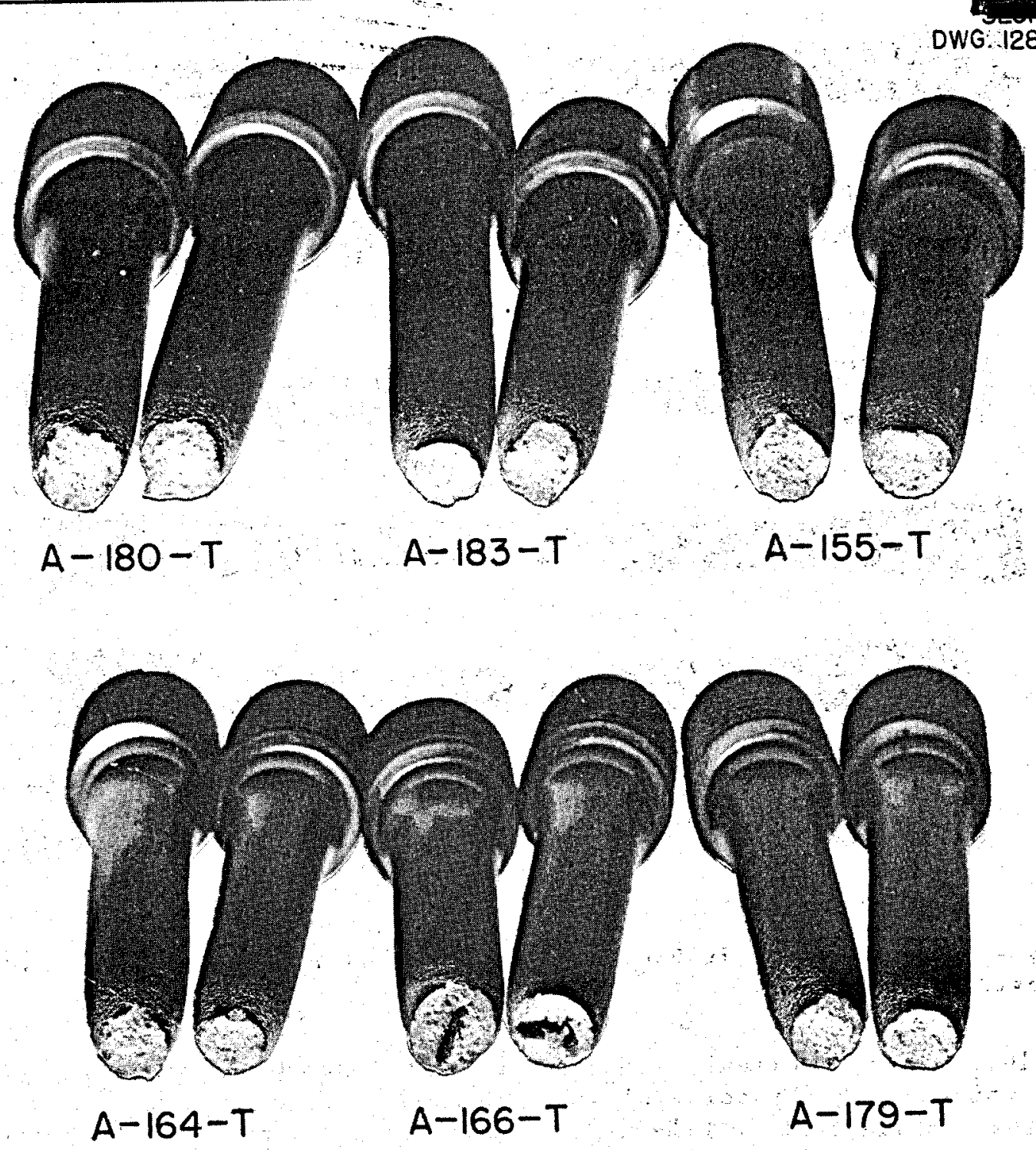

Fig. - Fractured Ames Thorium Tensile Specimens Annealed $1 / 2 \mathrm{hr}$ at $800^{\circ} \mathrm{C}$ Before Test.

yield point was not observed in any of the specimens heat-treated at $600^{\circ} \mathrm{C}$ or lower. The samplewhich was fully annealed at $750^{\circ}$ C showed a yield point, as would be expected, since this specimen is fully recrystallized. The only apparent effect of the heat treatments was the normal decrease in

$9210^{21}$ FEGRT 
INTER IM REPORT ON METALLURGY OF THORIUM : AND THORIUM ALLOYS

TABLE 2

Conventional Tensile-Test Data for Ames Thorium

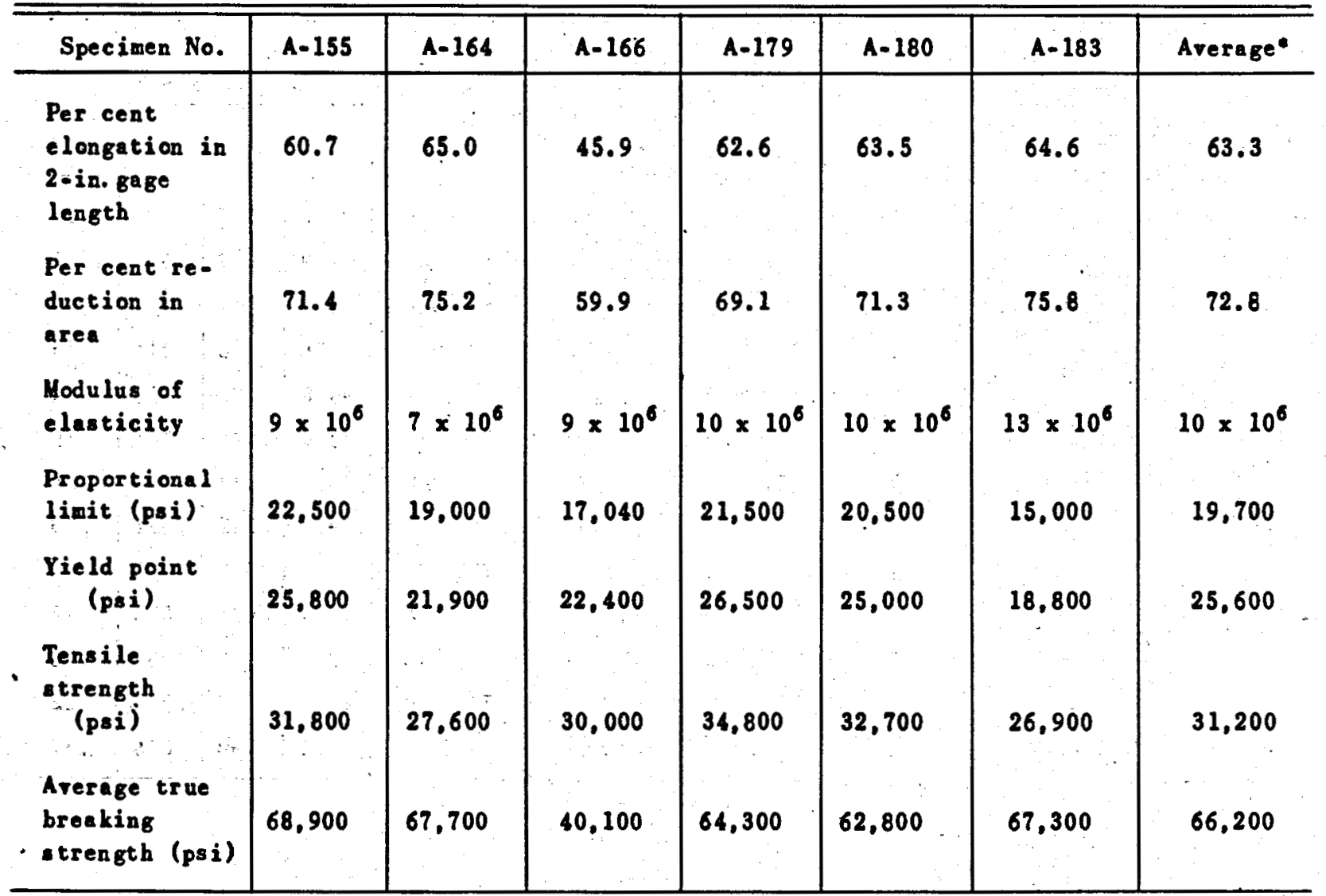

- Values for flawed specimen, A-166, not included.

proportional limit and yield strength (calculated at $0.2 \%$ of - -set) when annealed at successively higher temperatures. This is shown graphically in Fig. 14. Thus, in the case of thorium, it seems that temperatures very near the recrystallization temperature are required to cause the yield point to return.

The Ames thorium used for most of these tests contained approximately $0.02 \%$ nitrogen, while the thorium melted in an atmosphere of nitrogen contained $0.3 \%$ nitrogen. Attempts to fabricate tensile specimens by coldrolling failed because of the embrittlement associated with the high nitrogen content. Therefore, a standard round tensile-test specimen was machined from a cast ingot and pulled in tension. No yield point was observed, since there was no detectable plastic flow and the sample failed with a brittle break.

Two different lots of thorium, both of which showed yield point but differing in degree, were analyzed to establish the purity of the particular 
INTERIM REPORT ON METALLURGY OF THORIUM AND THORIUM ALLOYS

TABLE 3

Tensile-Test Data For Extruded Ames Thorium

\begin{tabular}{|c|c|c|c|c|c|c|c|c|c|}
\hline \multirow{2}{*}{$\begin{array}{l}\text { Specimen } \\
\text { No. }\end{array}$} & \multirow{2}{*}{$\begin{array}{c}\text { Per cent } \\
\text { Elongation } \\
\text { in } 2-\text { in. Gage } \\
\text { Length }\end{array}$} & \multirow{2}{*}{$\begin{array}{l}\text { Per cent } \\
\text { Reduction } \\
\text { in Area. }\end{array}$} & \multirow{2}{*}{$\begin{array}{l}\text { Yield } \\
\text { Point } \\
\text { (psi) }\end{array}$} & \multirow{2}{*}{$\begin{array}{l}\text { Tensile } \\
\text { Strength }\end{array}$} & \multirow{2}{*}{$\begin{array}{c}\text { Arerage } \\
\text { True } \\
\text { Breaking } \\
\text { Strength }\end{array}$} & \multicolumn{4}{|c|}{$\begin{array}{l}\text { Analytical Data } \\
\text { Per cent by } W_{t}\end{array}$} \\
\hline & & & & & & Th & C & $\mathrm{Be}$ & $\mathbf{S i}$ \\
\hline $223 \mathrm{~A}$ & 50. & 75 & 22,100 & 30,500 & 58,000 & 99.5 & .045 & .017 & .27 \\
\hline $222 \mathrm{C}$ & 52 & 71 & 20,750 & 30,300 & 60,300 & 99.9 & .053 & .017 & 0.35 \\
\hline $227 A$ & 51 & 74 & 21,100 & 29,750 & 52,000 & 99.6 & .051 & .022 & .18 \\
\hline $234 A$ & 52 & 74 & 22.700 & 31,050 & 58,000 & 99.6 & .050 & .014 & .11 \\
\hline $231 \mathrm{~A}$ & 54 & 74 & 27,970 & 34,200 & 72,500 & 99.8 & .070 & .021 & .14 \\
\hline $231 \mathrm{~B}$ & 48 & 74 & 27,500 & 34,750 & 75,000 & 98.9 & .076 & .021 & .19 \\
\hline $231 \mathrm{Cl}$ & 50 & 71 & 27.550 & 34,300 & 64,300 & 98.4 & .074 & .018 & .20 \\
\hline $231 \mathrm{C} 2$ & 52 & 73 & 27,400 & 34,500 & 72,300 & 99.4 & .062 & .034 & .70 \\
\hline $239 \mathrm{Cl}$ & 48 & 70 & 33,100 & 38,200 & 77,500 & 99.0 & .095 & .029 & .26 \\
\hline $239 \mathrm{D} 2$ & 46 & 70 & 31,900 & 38,900 & 79,400 & 98.8 & .084 & .028 & .22 \\
\hline $239 \mathrm{D}$ & 49 & 72 & 31,400 & 37,750 & 73,300 & 98.5 & .085 & .088 & .30 \\
\hline $239 B$ & 48 & 65 & 32,050 & 38,750 & 70,500 & 98.1 & .088 & .029 & .12 \\
\hline $239 \mathrm{~A}$ & 49 & 69 & 31,250 & 39,000 & 78,500 & 98.5 & .098 & .016 & .37 \\
\hline
\end{tabular}

lots of metal. The average results were as follows:

$\begin{array}{llll}\text { Lot } 1 & \text { Lot } 2 \\ \text { C } & 0.2 \% & \text { C } & 0.05 \% \\ \text { Si } & 0.2 \% & \text { Si } & 0.20 \% \\ \text { Be } & 0.5 \% & \text { Be } & 0.30 \% \\ \text { Th } & 99.1 \% & \text { Th } & 99.5 \%\end{array}$

The only appreciable variation in the analysis was the carbon content. The samples were tested at a constant strain rate of $0.1 \mathrm{in} / \mathrm{min}$. The samples of lot 1 containing $0.2 \%$ carbon did not show a lower yield point, although yielding occurred without an increase in stress. However, the samples of lot 2 containing approximately $0.05 \%$ carbon showed an upper yield point of 24,400 psi and a lower yield point of 23,500 psi. The effect of carbon content upon tensile strength of Ames thorium was reflected in the values obtained from these tests. The metal of lot lshowed tensile strengths. of 48,500 to 49,500 psi, while the low-carbon metal of lot 2 had a tensile strength of 32,000 psi.

Another indication that the yield point is sensitive to carbon content was found when a series of samples were tested at various strain rates to determine the effect of rate of strain 


\section{SERT}

\section{INTER IM REPORT ON METALLURGY OF THORIUM AND THORIUM ALLOYS}

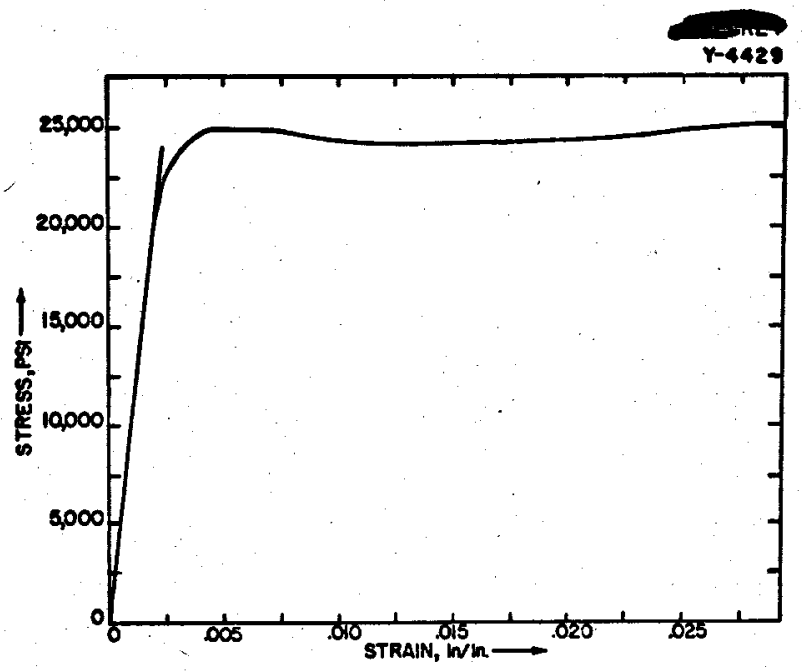

Fig. 6 - stress-strain Curve for Ames Thorium (Spec. A-180). Coldrolled $35 \%$, Annealed at $750^{\circ} \mathrm{C}$ for 1 hr.

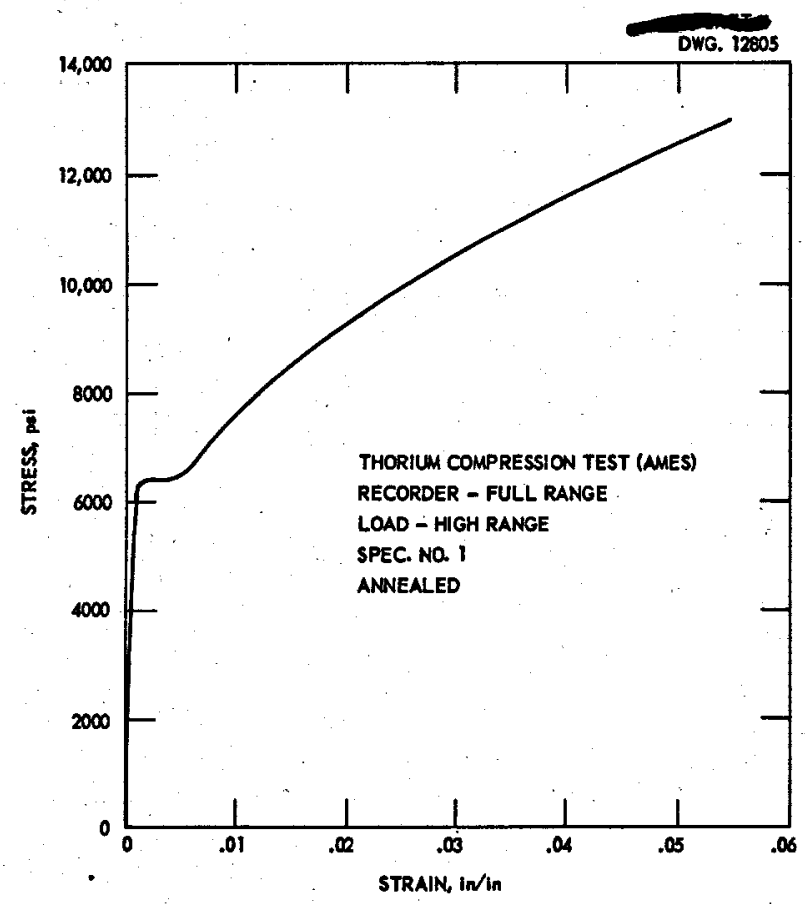

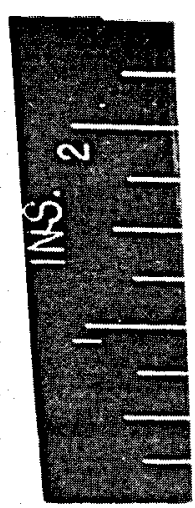

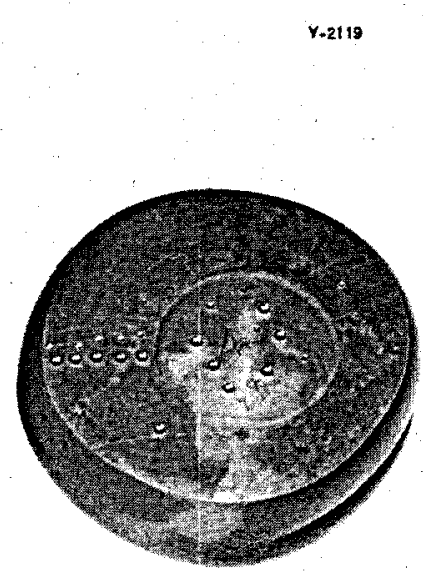

Fig. 8 - Compression specimen of Ames Thorium. Average hardness found in center of specimen, increasing hardness value from center to outside of specimen.

upon the yield point and tensile properties of Ames thorium. The analysis of this particular lot of metal used for this work was as follows: C, $0.15 \%$; $\mathrm{Be}, 0.3 \%$; $\mathrm{Si}, 0.4 \%$; Th, 98.7\%. Sheetmetal-type specimens 0.226 in. thick and 0.500 in wide were machined from cold-rolled sheet and fully annealed by heating at a temperature of $750^{\circ} \mathrm{C}$ for $1 / 2 \mathrm{hr}$. Tests were made at strain rates of $0.01,0.05$, and $0.20 \mathrm{in} / \mathrm{min}$.

None of the specimens showed a definite yield point. The yield strength, calculated at $0.2 \%$ off-set, was found to increase slightly with increasing strain rate. The tensile strength, too, was slightly affected by the strain rate, the greater strain rates resulting in higher values of tensile strength. The data are given in Table 7 .

Fig. 7 - stress-strain curve for was hoped that a high nitrogen Ames Thorium in Compression Tests. content ight accentuate the yield 


\section{INTER IM REPORT ON METALLURGY OF THORIUM AND THORIUM ALLOYS}

TABLE 4

Vickers and Rockwell Hardness - Ames Compression Test Bars

Average Vickers and Fockwell Hardness Values Determined from

Ten Tests in the Center of the Original Cross-Section

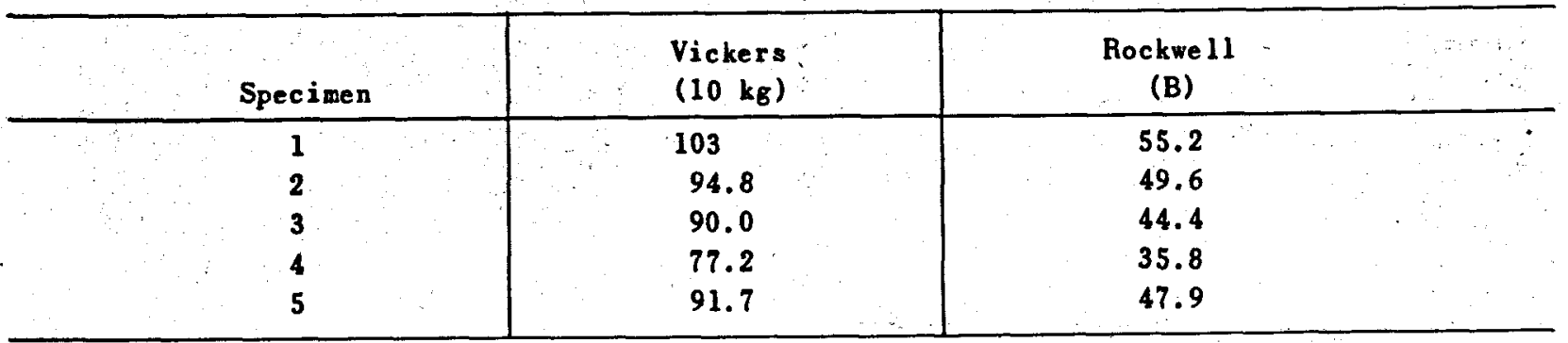

Vickers and Rockwell Hardness Taken from the Center to the Outside of the Compressed Specimen

(A center - E outside)

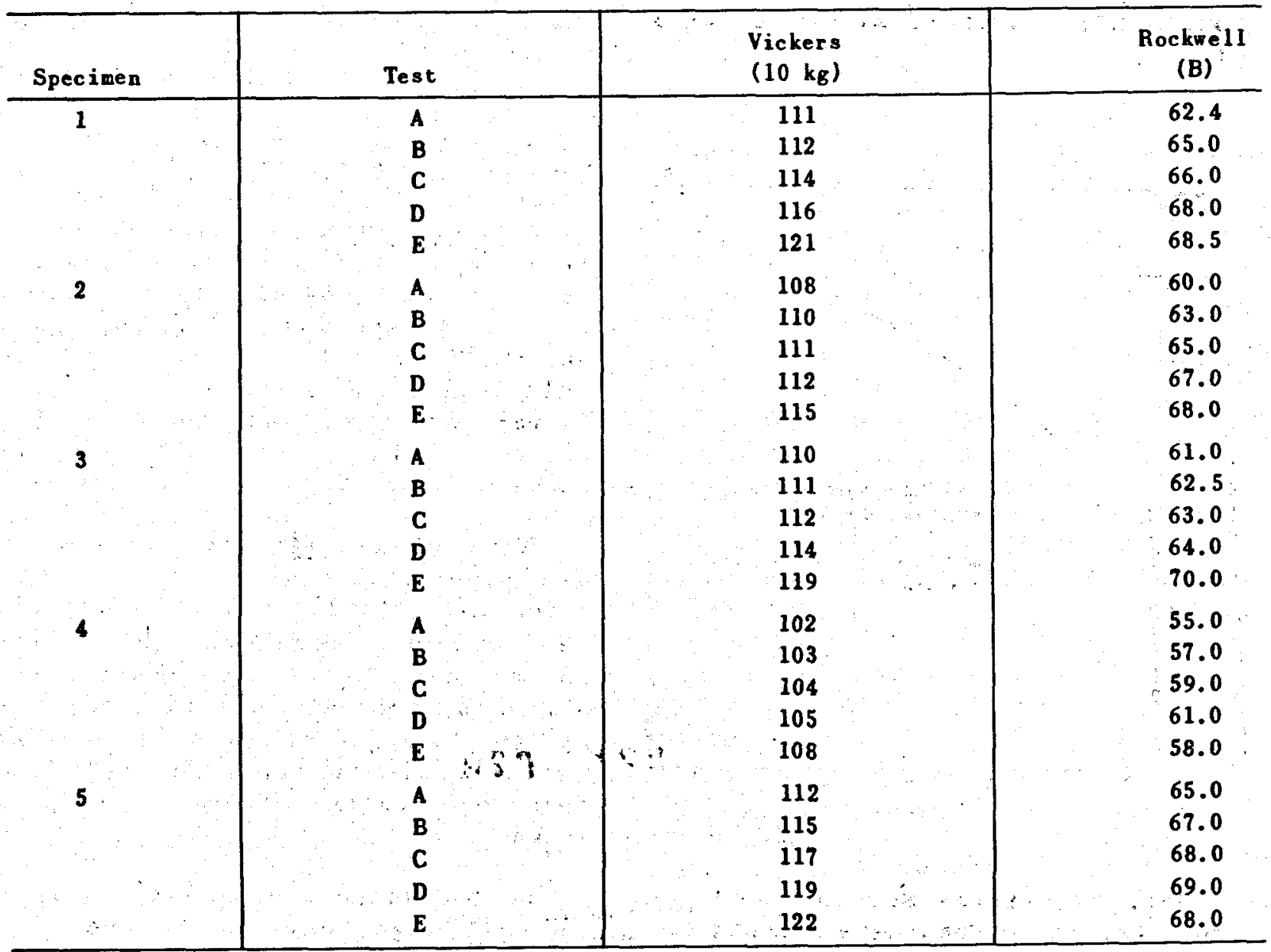




\section{INTERIM REPORT ON METALLURGY OF THOR IUM. ANB $\rightarrow$ HORIUM ALLOYS}

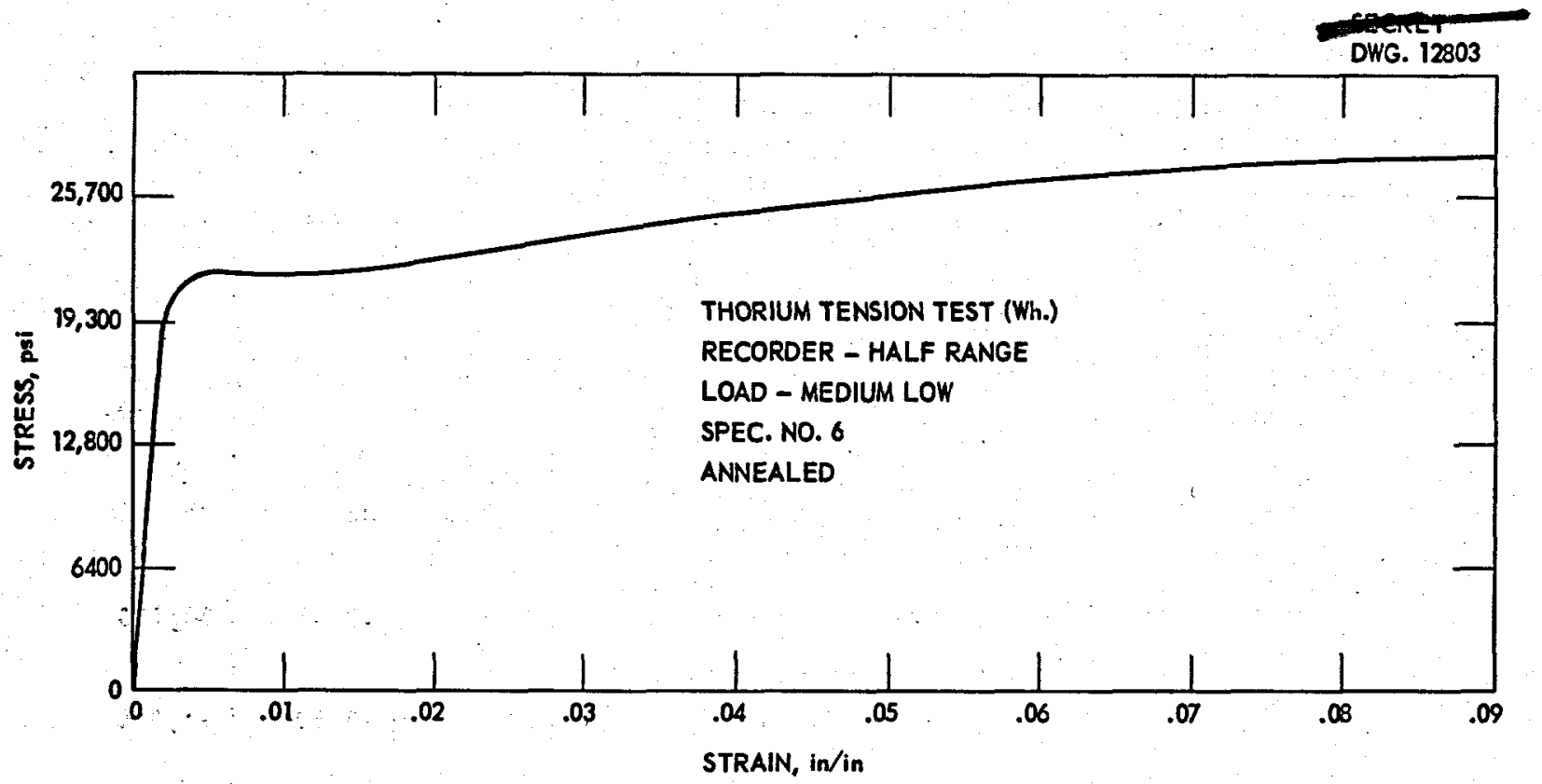

Fig. 9 - Stress-Strain Curve for Westinghouse Thorium $k$ in. Square Bars Annealed at $750^{\circ} \mathrm{C}$ for $1 \mathrm{hr}$.

point, since it has been shown that nitrogen is a contributing factor in the appearance of a yield point in luw-carbon steel and in single crystals of cadmium and zinc. (4) A recent theory (Cottrell 1948) suggests that the yield point is caused by, the segregation of solute atoms (carbon or nitrogen) to dislocations. The attraction of dislocations to the segregated atoms provides a bond which has to be borken by a larger force than is necessary to maintain free dislocations in motion; the material thus gives way suddenly and softens at the start of plastic flow, producing a sharp yield point. The theory also explains the observed removal of the yield point by plastic over-strain and its return on strain aging. A freshly strained specimen contains.freed dislocations and does not show yield point; but on aging, these dislocations become anchored by migration of solute atoms to them and the yield point has returned.

Thorium-titanium, thorium-chromium, thorium-zirconium, and thorium-titanium-zirconium alloys were prepared to determine the effect of alloying upon the yield point. The alloys which contained $T i$ did not show a yield point when tested with a crosshead speed of $0.1 \mathrm{in} / \mathrm{min}$. All other alloys showed a definite yield point when tested under the same conditions of loading. Presumably, the titanium could tie up the nitrogen or carbon atoms and prevent their migration to dislocations.

Torsion Testing - The shear modulus of thorium has been measured, and the average value of shear modulus for

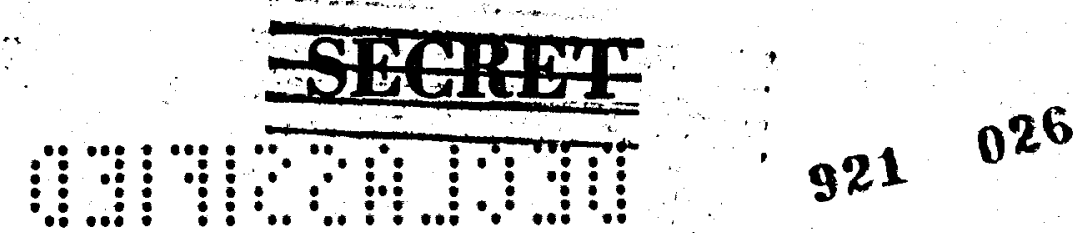




\section{INTERIM REPORT ON METALLURGY OF THORIUM AND THORIUM ALLOYS}

TABLE 5

Conventional Tensile-Test Data for Westinghouse Thor ium

\begin{tabular}{c|r|r|r|r|r|r|r}
\hline Specimen & 1 & 2 & 3 & 4 & 5 & 6 & 7 \\
\hline $\begin{array}{c}\text { Elongation, \% in } \\
\text { in }\end{array}$ & 15 & 12 & 12 & 6 & 9 & 9 & 6 \\
$\begin{array}{c}\text { Reduction in area, } \\
\%\end{array}$ & 7.7 & 13 & 3.6 & 9 & 9.5 & 6.9 & 16.1 \\
$\begin{array}{c}\text { Tensile strength, } \\
\text { psi }\end{array}$ & 28,000 & 27,500 & 30,500 & 26,300 & 28,600 & 28,400 & 25,800 \\
$\begin{array}{c}\text { Ultimate Strength, } \\
\text { psi }\end{array}$ & & 32,700 & 31,500 & 28,900 & 31,600 & 30,800 & 30,700 \\
$\begin{array}{c}\text { Proportional limit, } \\
\text { psi } \\
\text { Rockwell hardness } \\
\text { (B scale) }\end{array}$ & 13,300 & 15,600 & 16,200 & 17,500 & 19,600 & 18,300 & 14,300 \\
$\begin{array}{c}\text { Vickers hardness } \\
\text { (10 kg) }\end{array}$ & 44 & 39 & 41 & 41 & 42 & 41 & 31 \\
\hline
\end{tabular}

Note: Specimens 1-3 were tested as received. Specimens 4-7 were annealed at $750^{\circ} \mathrm{C}$ for $/ / 2 \mathrm{hr}$ before testing.

three specimens of Ames thorium was found to be $4,260,000 \mathrm{lb} / \mathrm{sq}$ in.

Torsion tests were made on a crude torsion-test machine, using solid specimens 0.590 in. in diameter and 6 in. long. Angle of twist was measured over a length of 4.20 in. and was determined by measuring deflection of lever arms with a dial indicator. As a check on the machine and on the accuracy of critical measurements, experimental values of shear modulus for steel and $2 S$ aluminum were also measured. Results are shown in Table 8. The average shear modulus found for steel is about $3 \%$ below the accepted handbook value, but the experimental values for aluminum agree almost exactly with the handbook value.

Impact Strength - The impact strength of Ames thorium was determined at temperatures ranging from $-196^{\circ} \mathrm{C}$ to $240^{\circ}$ C. Standard V-notch Charpy-type specimens were tested in a Sonntag Universal. Impact testing machine.

The first work was performed on specimens machined from different lots of rolled Ames thorium. These samples were tested at $-196^{\circ} \mathrm{C},-80^{\circ} \mathrm{C}$, $0^{\circ} \mathrm{C}, 100^{\circ} \mathrm{C}$, and $280^{\circ} \mathrm{C}$. Three specimens were broken at each temperature, and since there was considerable scatter in the data, it was thought 


\section{INTERIM REPORT ON METALLURGY OF THORIUM AND THORIUM ALLOYS}

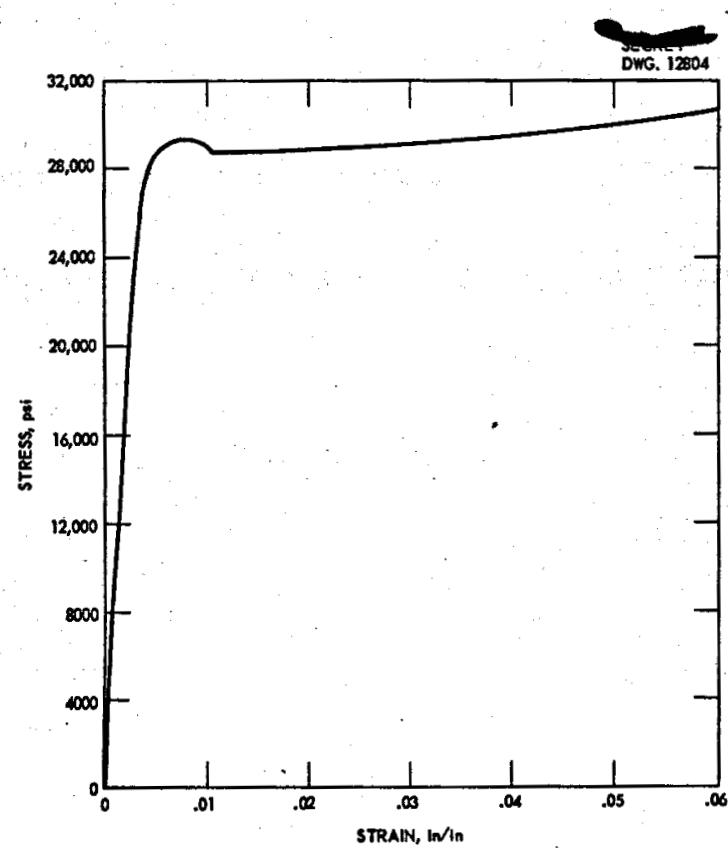

Fig. 10 - Thorium Tension Test (Ames): Recorder - Full Range; Load Hediun Low; Spec. No. s; Annealed.

that the impact strength must be fairly sensitive to variation in purity of the metal. Therefore, a single piece of Ames thorium was rolled into plate $5 / 8$ in. in thickness, from which about 50 specimens were machined. Thus, enough impact specimens were obtained from one lot of metal for complete testing of the same material. The V-notch Charpy specimens were machined from the plate and racuum annealed at $750^{\circ} \mathrm{C}$ for $1 / 2 \mathrm{hr}$. The specimens were brought to the proper testing temperature in bath with the various temperatures being obtained as follows: $-196^{\circ} \mathrm{C}$, liquid nitrogen; $-80^{\circ} \mathrm{C}$, dry ice and

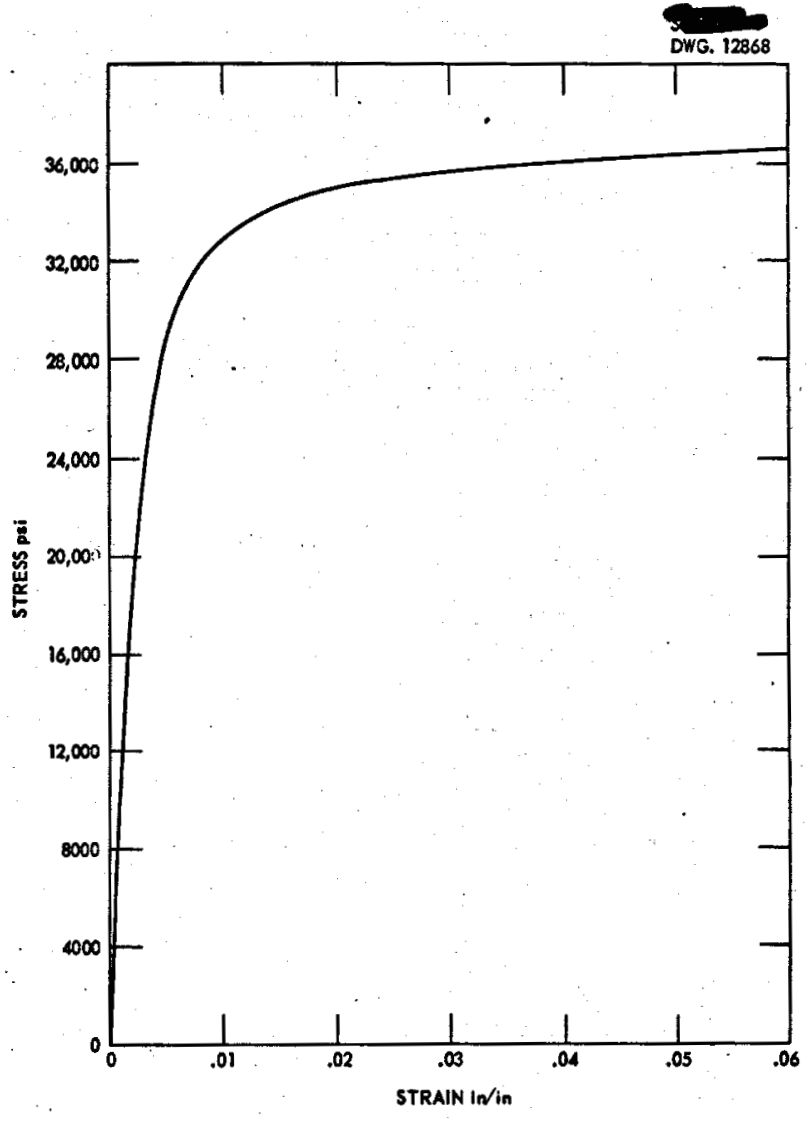

Fig. 11 - Thortum Tension. TeBt (Ames): Recorder - Ful1 Range; Load Hedium Low; Spec. No. 9; Cold-rolled.

acetone; $0^{\circ} \mathrm{C}$, ice water; $20^{\circ} \mathrm{C}$, room temperature; $100^{\circ} \mathrm{C}$, boilingwater; higher temperatures, oil bath. The specimens were handled with tongs which were at the same temperature as the specimen and were transferred quickly from the holding bath to the anvil of the machine, where they were broken immediately. The testing temperature, therefore, was essentially the same as the bath temperature. The actual testing temperatures and the impact strength of thorium at these temperatures is given in Table 9. The

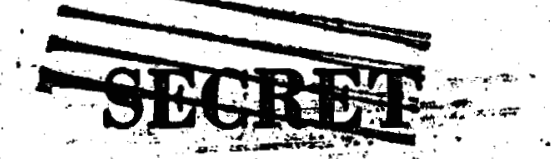




\section{INTERIM REPORT ON METALLURGY OF THORIUM AND THORIUM ALLOYS}

TABUE 6

Ames Thorium - Conventional Tensile-Test Data for Sheet-lietal Specimen

\begin{tabular}{l|r|r|r|r|r|r}
\hline \multicolumn{1}{c|}{ Specimen } & 3 & 5 & 6 & 7 & 8 & 9 \\
\hline Elongation, $x$ in 2 in. & 50 & 51.5 & 40.6 & 39.8 & 42.9 & 37.5 \\
Reduction in area, \% & 64 & 62 & 61 & 60 & 60 & 57 \\
Tensile strength, psi & 32,900 & 35,800 & 36,800 & 30,900 & 39,700 & 40,800 \\
Ultimate strength, psi & 50,900 & 59,400 & 61,500 & 49,500 & 62,800 & 62,300 \\
Proportional limit, psi & 18,700 & 25,600 &.- & 19,200 &.- & 25,600 \\
Hockwell hardness (B sca le) & 37 & 50 & 54 & 38 & 59 & 56 \\
Vickers hardness (10 kg) & 83 & 92 & 99 & 79 & 102 & 102 \\
\hline
\end{tabular}

Note: Specimens 5 and 7 were annealed at $750^{\circ} \mathrm{C}$ for $/ 2 \mathrm{hr}$ and tested. Specimens $3,6,8$ and 9 were annealed $750^{\circ} \mathrm{C}$ for $\mathrm{k} \mathrm{hr}$, then cold-rolled 5\%. Extensometer readings on 6 and 8 were faulty, and the proportional limit could not be determined.
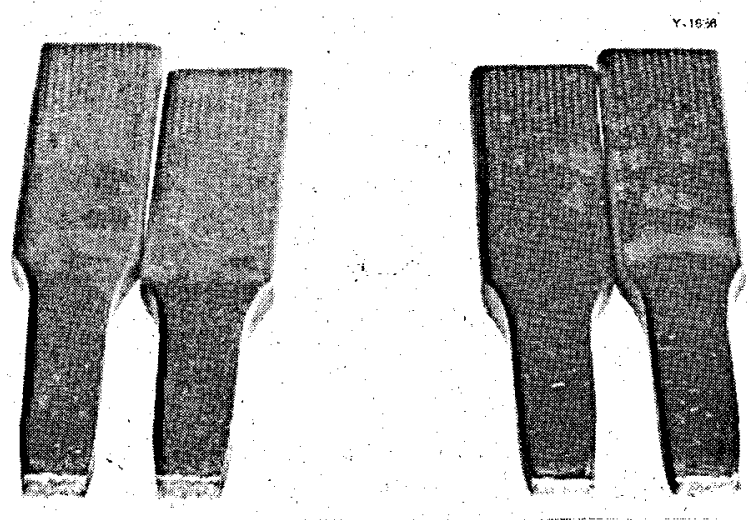

Fig. 12 - Fractured Tensile Specimens of Annealed Ames Thorium.

impact energy in $f t-1 b$ is plotted as a function of temperature in Fig. 15. The scatter found in earlier data was eliminated and a relatively smooth curve was obtained, showing that Ames thorium tested by notched-bar impact tests exhibits a transition frombrittle to tough behavior, i.e., impact strength increases with increasing temperature over a moderately narrow range of temperature. The types of fracture found in the temperature range studied are shown in Fig. 16. The samples tested at a temperature of $240^{\circ} \mathrm{C}$ absorbed the maximum energy of the impact machine, $120 \mathrm{ft}-1 \mathrm{~b}$, without breaking.

Iodide Thorium - Since the iodide thorium is deposited in a relatively noncoherent form, it is necessary to consolidate the metal before testing. The metal is deposited as a dense polycrystalline core approximately .01 in. in diameter around the .003 in.diameter starting wire filament. The remaining deposit is in the form of long radial needles, which apparently are not well bonded to each other. A typical crystal bar together with a photonicrograph of the cross-section is shown in Fig. 17. In order to put the metal into workable form, the 


\section{INTERIM REPORT ON METALLURGY OF THOKIUM AND THORIUM ALLOYS}
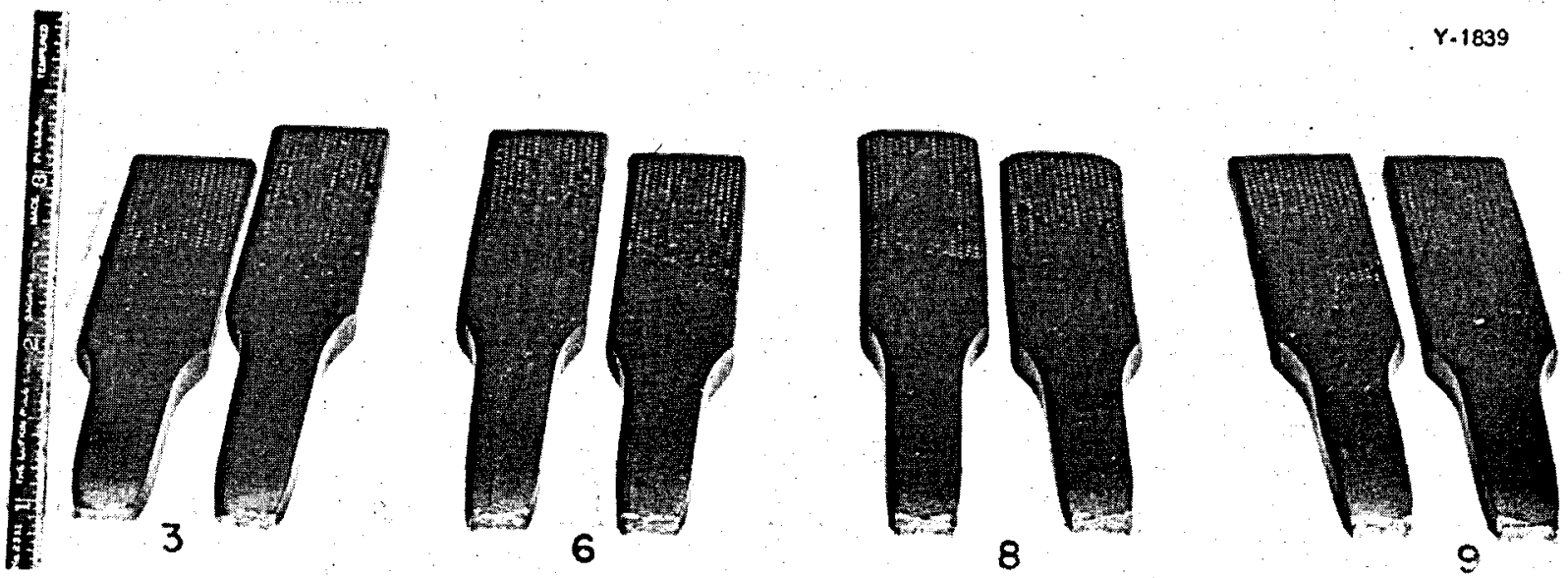

Fig. 13 - Fractured Tensile Specimens of cold-rolled Ames Thorium.

- crystal bar thorium was melted in a vacuum arc furnace, using the thorium as a consumable electrode. The melt was collected in water-cooled copper crucible and ingots $1-1 / 4$ in. in diam:eter and 4 in. long were prepared in this way. The vacuum arc furnace is shown in Fig. 18. A melted ingot and the unmelted portion of the electrode are shown in Fig. 19.

The ingot was scalped and rolled into a cylindrical bar from which a standard 0.357-in.-diameter tensile test specimen was prepared. The specimen was annealed at $750^{\circ} \mathrm{C}$ for $1 / 2 \mathrm{hr}$ and a coarse-grained specimen resulted. The microstructure, Fig. 20 , did not show any impurity phases. The tensile specimen was fitted with two SR-4 strain gages to read transverse strain and two gages to read longitudinal strain. The sample was loaded and unloaded within the elastic limit a number of times and the data used to calculate Poisson's ratio and modulus of elasticity. The elastic modulus was found to be the same as for Ames thorium, $10 \times 10^{6} \mathrm{psi}$.
Poisson's ratiowas calculated as 0.30 . The specimen was pulled to failure and it was found that the value of 22,860 psi obtained as the tensile strength of iodide thorium was considerably lower than that of Ames thorium, which was approximately $32,000 \mathrm{psi}$.

A sheet-metal-type specimen was tested also, having the tensile-test data as follows:

$$
\begin{array}{lr}
\begin{array}{l}
\text { Elongation in 2-in. } \\
\text { gage length }
\end{array} & 40.6 \% \\
\text { Proportional limit } & 4,100 \text { psi } \\
\text { Tensile strength } & 14,770 \text { psi }
\end{array}
$$

In both the round and sheet-metal specimens, there was a very large reduction in cross-sectional area at the break, since the specimens necked down very rapidly. It was impossible to measure the final area of the sheetmetal specimen, since the break appeared to be a knife edge at a magnification of $200 X$. The fractured round specimen is shown in Fig. 21. No yield point was found in the loadelongation curves for iodide thorium.

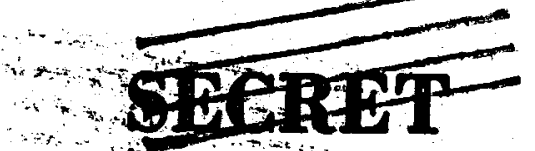




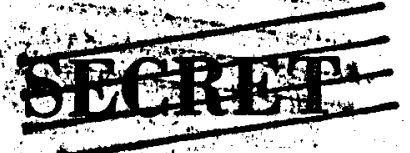

INTERIM REPORT ON METALLURGY OF THORIUM AND THORIUM ALLOYS

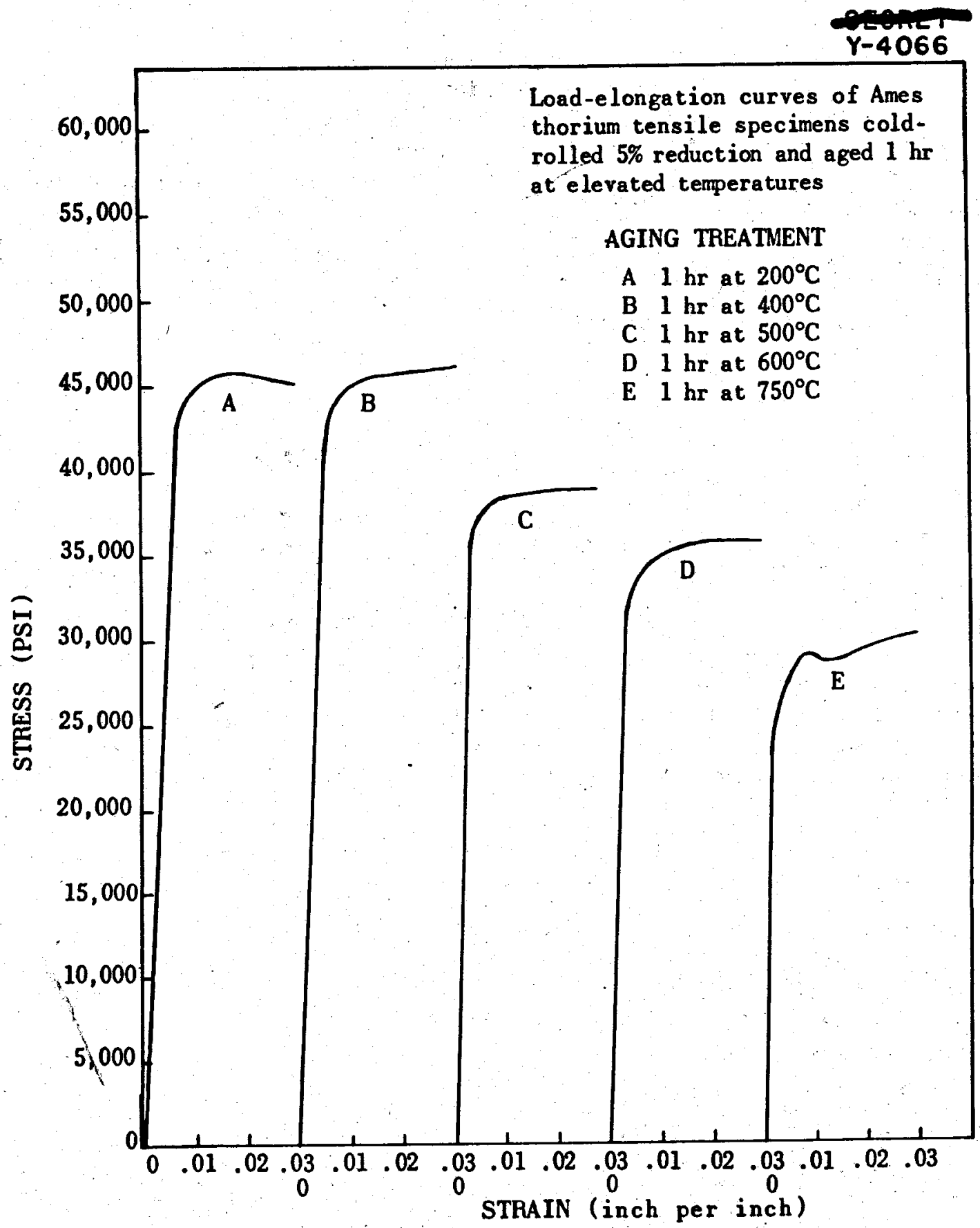

Fig. 14 - Effect of Elevated Temperature Aging Upon Yield Point in Ames Thorium. 
TABLE 7

Ef fect of Strain Rate on Tensile Strength of Ames Thorium

\begin{tabular}{c|c|c|c}
\hline \hline Specimen No. & $\begin{array}{c}\text { Strain Rate } \\
\text { (in/min) }\end{array}$ & $\begin{array}{c}\text { Tensile Strength } \\
\text { (psi) }\end{array}$ & $\begin{array}{c}\text { Yield Strength, psi } \\
\text { (calc. at 0.2\% of fset) }\end{array}$ \\
\hline 1 & 0.2 & 36,500 & 25,400 \\
3 & 0.05 & 34,600 & 23,000 \\
4 & 0.05 & 34,600 & 21,600 \\
2 & 0.01 & 33,200 & 20,900 \\
\hline
\end{tabular}

TABLE 8

Shear Modulus of Thorium and Other Haterials

\begin{tabular}{|c|c|c|}
\hline & \multicolumn{2}{|c|}{ Shear Modulus ( $1 \mathrm{~b} / \mathrm{ag}$ in) } \\
\hline Material & $\begin{array}{c}\text { Experimental } \\
\text { Values }\end{array}$ & $\begin{array}{c}\text { Handbook } \\
\text { Value }\end{array}$ \\
\hline Stee 1 & $11,540,000$ & \\
\hline Stee 1 & $11,300,000$ & \\
\hline Stee 1 & $11,250,000$ & \\
\hline Arerage Steel & $11,360,000$ & $11,700,000$ \\
\hline Aluminum & $3,860,000$ & \\
\hline Aluminum & $3,850,000$ & \\
\hline Arerage Aluminum & $3,855,000$ & $3,850,000$ \\
\hline Ames Thorium & $4,210,000$ & \\
\hline Ames Thorium & $4,270,000$ & \\
\hline Ames Thorium & $4,300,000$ & \\
\hline Arerage Thorium & $4,260,000$ & ; \\
\hline
\end{tabular}

\section{WORK - HARDENING OF THORIUM}

It was noted that thorium does not work-harden to any great extent during cold rolling; since plate and sheet may be reduced in thickness as much as $99 \%$ without intermediate annealing and without extreme change in hardness. Preliminary tests on rate of workhardening of Ames thorium showed that most of the hardening occurred very
TABLE 9

Impact Strength of Ames Thorium

\begin{tabular}{c|c}
\hline & Foot-Pounds to \\
Temperature $\left({ }^{\circ} \mathrm{C}\right)$ & $11.5 ; 13.5$ \\
\hline-195 & $13.5 ; 15.0$ \\
-80 & 15.0 \\
-60 & 18.0 \\
-40 & 19.0 \\
-20 & 20.0 \\
0 & $21.0 ; 22.0$ \\
20 & $22.0 ; 23.0$ \\
60 & 31.0 \\
100 & 44.0 \\
120 & 50.0 \\
130 & $59.0 ; 61.0$ \\
140 & 66.0 \\
150 & $69.0 ; 71.0$ \\
160 & 78.0 \\
170 & 88.0 \\
180 & 99.0 \\
190 & $108.0-; \quad 107.0$ \\
200 & $114.0-; \quad 114.0$ \\
220 & Specimen not broken \\
240 & atimit of machine \\
& $(120$ ft-1b) \\
\hline &
\end{tabular}

early in the rolling operation. Therefore, a piece of Ames thorium was

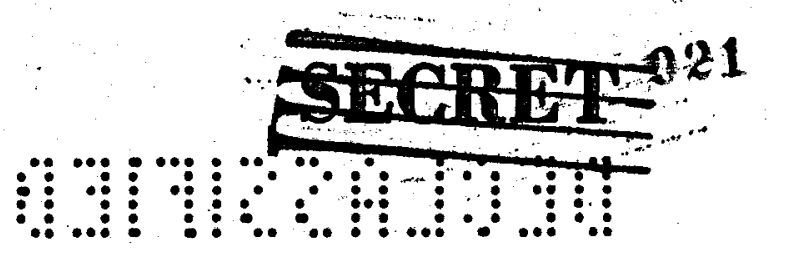




\section{INTER IM REPORT ON METALLURGY OF THOR IUM AND THORIUM ALLOYS}

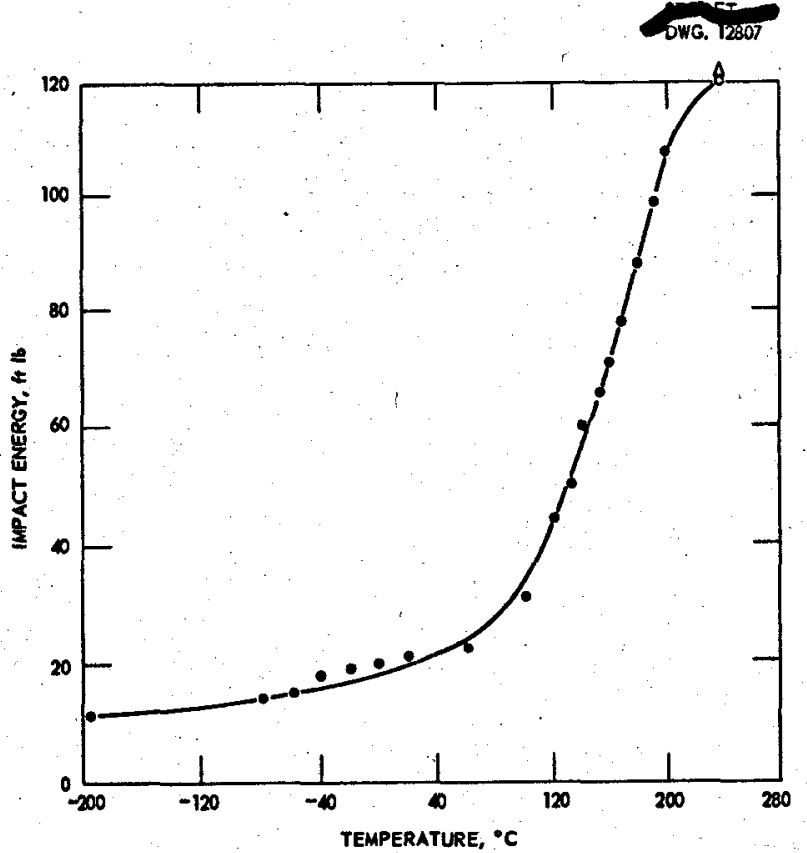

F1g. 15 - Impact Energy for Pure Ames Thorium standard V-notch Charpy Specimens.

cold-rolled to $99.9 \%$ reduction with samples being cut from the original piece after each $5 \%$ reduction in thickness. Owing to the initial high rate of work-hardening, smaller increments of cold-working were used up to $10 \%$ reduction. Hardness data and degree of cold-working are shown in Fig. 22 . The hardness values shown are averages of some ten measurements, and individual measurements were found to be very uniform and consistent. Beyond $10 \%$ reduction, the rate of work. hardening is very small, as shown graphically in Fig. 22. The total change in hardness, even with large amounts of cold-working, is comparatively small (DPH 85 to 135). Different lots of thorium give different results in that the maximum attainable hardness as well as the original hardness is sometimes less than shown in Fig. 22. However, the work-hardening curve shown in Fig. 22 is representative of the Ames thorium used for the major part of the work at this laboratory. The variation in hardness is presumably due to differences of impurities in the metal.

A work-hardening curve was obtained from thorium of the highest purity available, iodide thorium. The thorium as deposited was melted in a vacuum arc furnace to yield massive, workable ingots. The original hardness of the ingot as melted was 42 vickers. The following analysis is typical of the arc melted material: $0_{2}=0.012 \% ; \mathrm{N}_{2}$ - not detected; $\mathrm{H}_{2}=$ $0.0002 \%$; $C=0.05 \%$; faint trace of Ca. No other elements were detected in a spectrographic analysis. The ingot was rolled into a flat sheet and annealed by heating to $700^{\circ} \mathrm{C}$ for one hour. The hardness after annealing was 36 vickers. The sheet was cold rolled for a total of $97.5 \%$ reduction in thickness with hardness measurements being made after each $1 \%$ reduction up to $5 \%$ total reduction and after each $5 \%$ reduction for the remainder of the rolling. The rolling was accomplished without any evidence of cracking. The work-hardening curve, Fig. 23, has the same form as that for Ames thorium, the only difference being that the iodide thorium is a much softer and more ductile material.

\section{RECRYSTALL IZATION}

Ames Thorium - Isothermal recrystallization curves have been determined for Ames thorium and iodide thorium by measuring the change in hardness found after heating cold-worked specimens for varying lengths of time at a constant temperature.

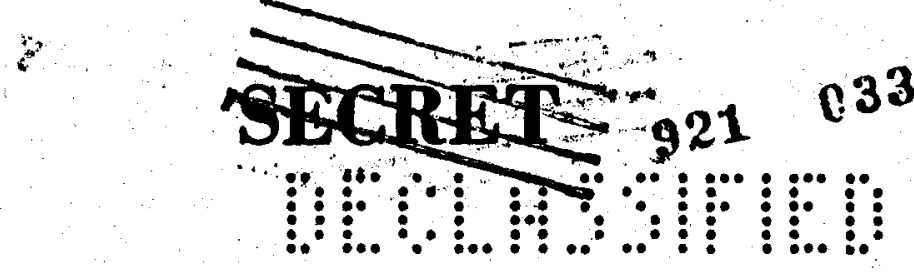




\section{INTERIM REPORT ON METALLURGY OF THOR IUM AND THORIUM ALLOYS}

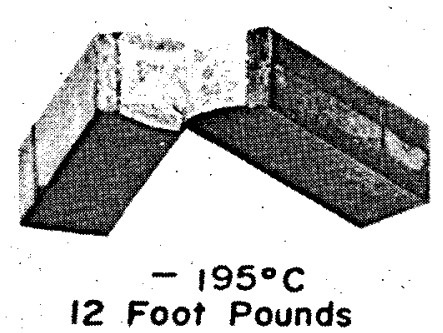

12 Foot Pounds

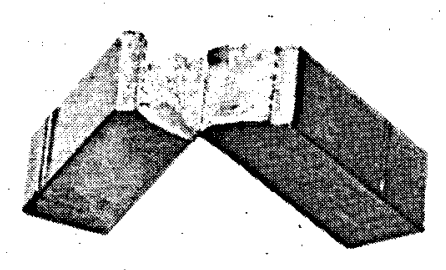

$-80^{\circ} \mathrm{C}$

14 Foot Pounds

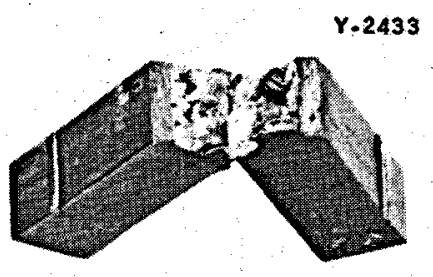

$-0^{\circ} \mathrm{C}$

21 Foot Pounds

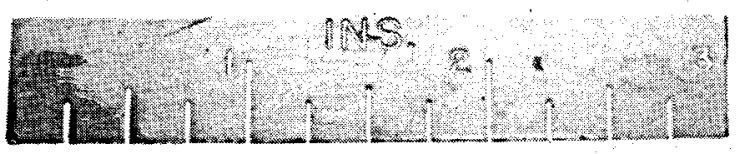

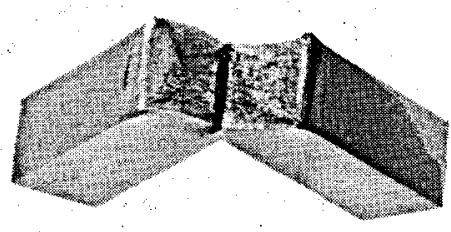

$60^{\circ} \mathrm{C}$

23 Foot Pounds

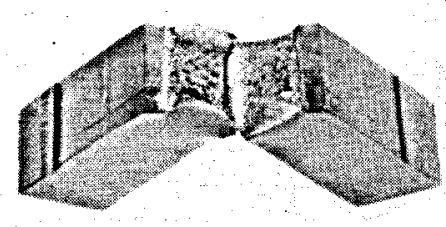

$120^{\circ} \mathrm{C}$

44 Foot Pounds

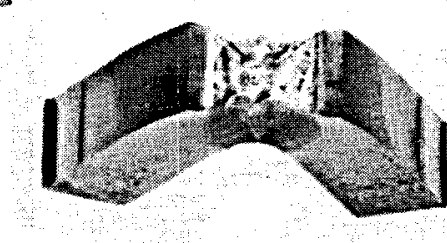

$240^{\circ} \mathrm{C}$

Fig. 16 - Fractured Charpy-Type Impact Specimens of Ames Thorium.

The specimens were prepared by cold-rolling fully annealed thorium plate to the desired reduction. Preliminary data were obtained from samples rolled to 30,50 , and $80 \%$ reduction in area. The recrystallization data obtained in the case of the $30 \%$ reduction were somewhat erratic. Since recrystallization is known to be a process of nucleation and growth, and consequently a function of time, temperature, and reduction, it was felt that the first work should be concerned with a severely cold-worked sample annealed at temperatures where complete recrystallization might be expected. By starting with a severely cold-worked specimen, one would expect enough nuclei to be present to largely eliminate rate of nucleation as a controlling factor in the recrystalliza- tion process. Therefore, $80 \%$ reduction, which gave the most consistent results, was chosen for the initial work.

Ames thorium which was forged at

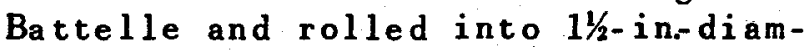
eter bars at Westinghouse was used as the starting material. This metal contained approximately $0.07 \% \mathrm{C}, 0.15 \%$ $\mathrm{O}_{2}, 0.07 \% \mathrm{~N}_{2}$, and traces of $\mathrm{Ca}, \mathrm{Fe}$,

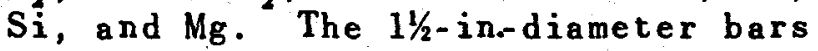
were cold-rolled slightly to form a flat bar, annealed at $750^{\circ} \mathrm{C}$ for $1 \mathrm{hr}$, and further cold-rolled for $80 \%$ reduction in axea to produce a flat plate $1 / 8$ in. in thickness. The rolled. plate was cut into specimens measuring approximately 1 in. by 1 in. by $1 / 8$ in., and a group of samples were suspended in a salt bath which was maintained at 


\section{INTERIM REPORT ON METALLURGY OF THORIUU AND THORIUM ALLOYS}
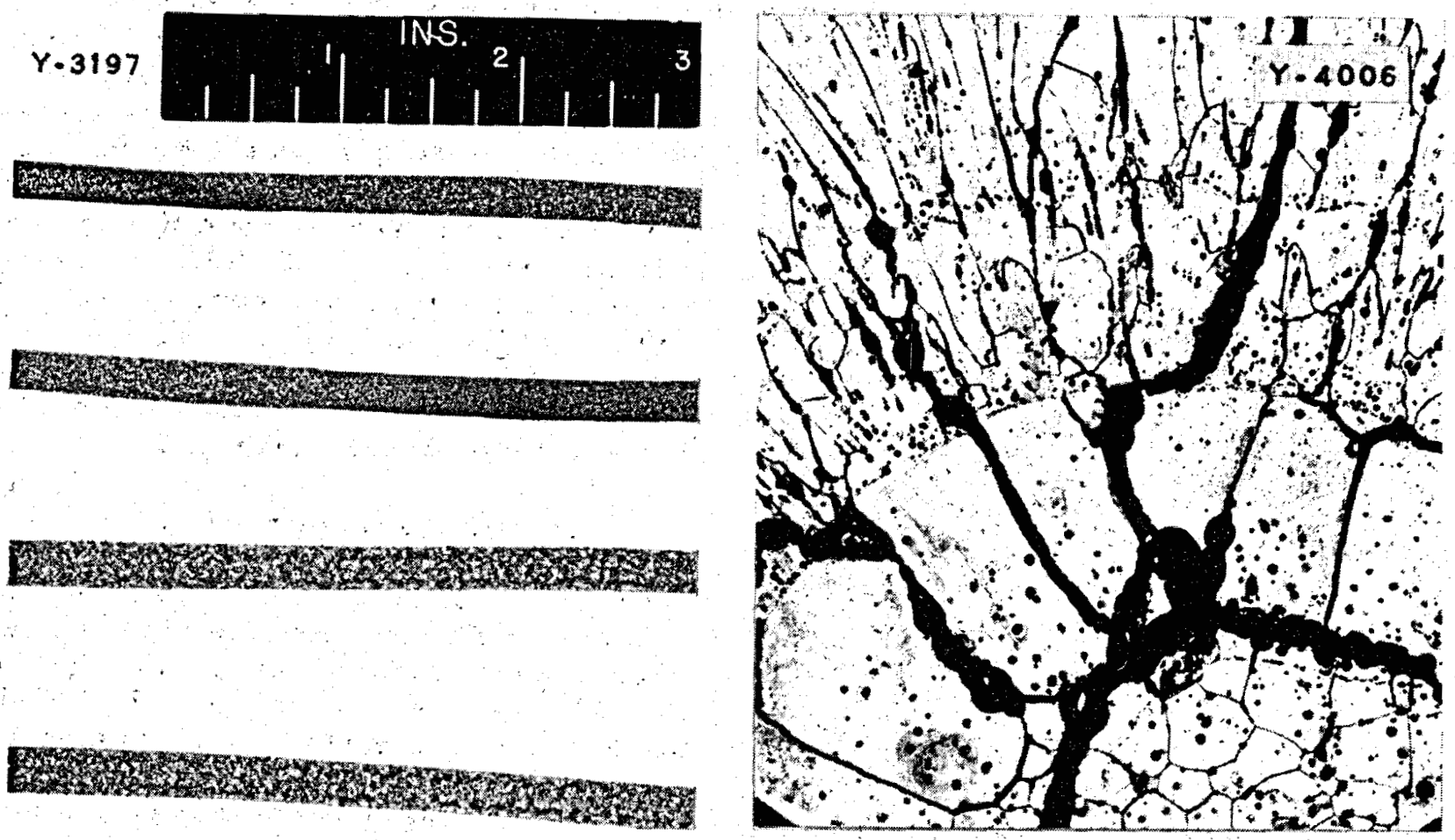

$110 x$

As-deposited crystal bar

Photomicrograph of as-deposited crystal bar

Fig. 17 - Iodide Thorium Metal Prepared by the Van Arkel-De Boer Process.

a constant temperature in a Hevi-duty. pot furnace. The temperature was controlled and recorded by means of a Micromax controller with an accuracy. of $\pm 2^{\circ}$ C. Since recrystallization is time-dependent, it was important to know the length of time required to bring the specimen to the bath tem. perature. The time required to bring the sample to testing temperature was determined experimentally by welding thermocouples to the specimens and measuring the time for bringing the specimen to the bath temperature. In all cases the time was less than 10 sec. Consequently, the preheating time was insignificant except at high temperatures where recrystallization proceeded rapidly. The specimens were removed individually from the bath after various time intervals and tested for hardness with a Vickers. Hardness Tester.

The hardness of the heat-treated metal was plotted as a function of time at constant temperature. Such recrystallization curves for Ames thorium are shown in Fig. 24, and there appears to be no evidence of

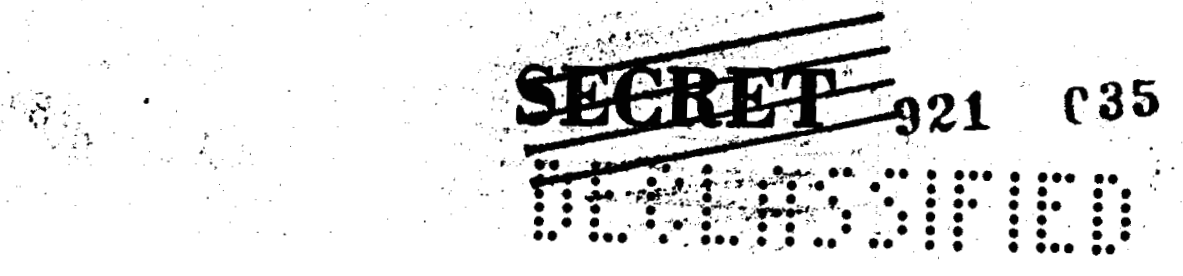




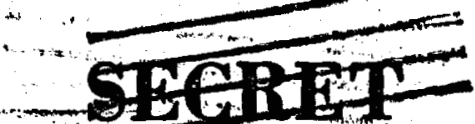 \\ arim

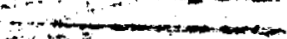

INTER IM REPORT ON METAEEUTG OF THORIUM AND THORIUM ALLOYS

\section{UNCLASSIFIED}

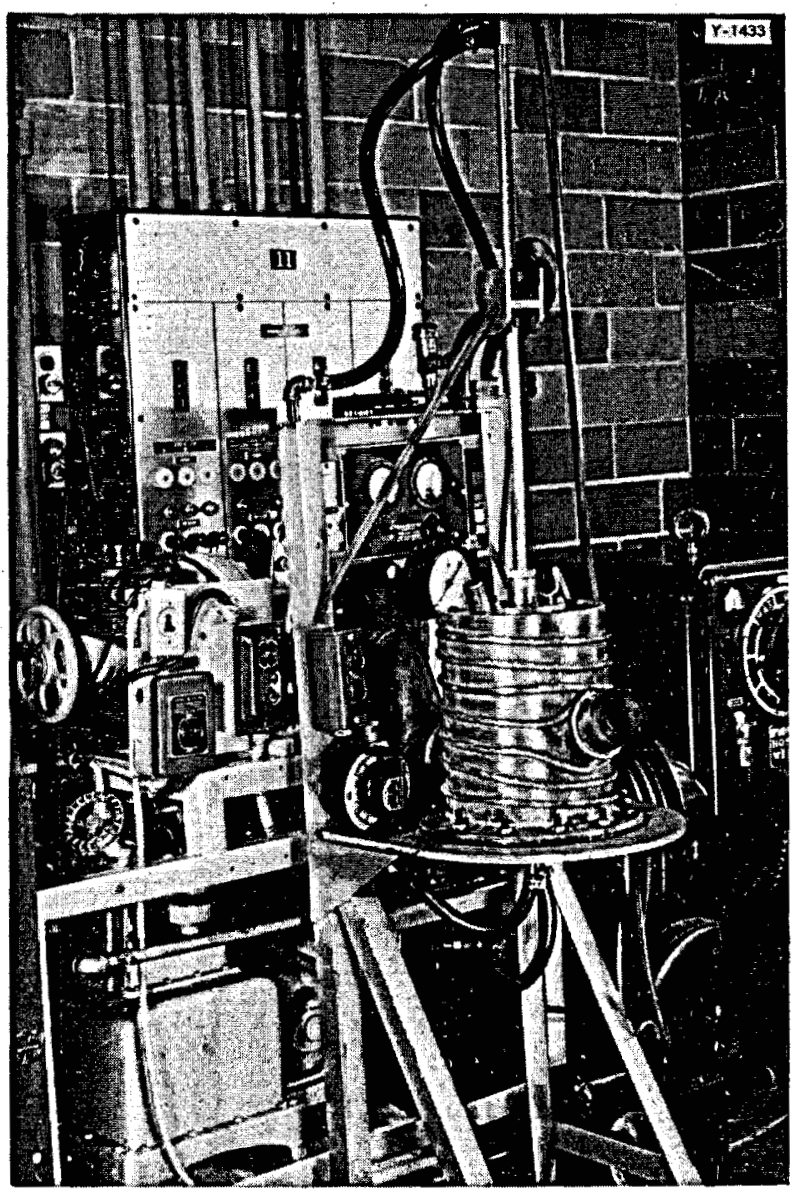

Fig. 18 - Vacuum Arc Furnace

recovery prior to recrystallization. Photomicrographs of specimens coldrolled to $80 \%$ reduction and recrystallized at $550^{\circ} \mathrm{C}$ are shown in $\mathrm{Fig} .25$. This material had a small grain size (average rain diameter $0.010 \mathrm{~mm}$ ), and no teridency for grain growth was noted after long-time annealing.

The assumption is made that the hardness of cold-worked thorium metal is directly proportional to the amount of recrystallization. This almost certainly is not true; however, it is felt that it is a reasonable approxi- mation, at least in the case of the curves obtained at $550^{\circ} \mathrm{C}$ or higher. It should be noted, in Fig. 25, that the shape of the curve changes markedly over the narrow temperature range between $535^{\circ}$ and $550^{\circ} \mathrm{C}$. It is possible that recoverymayenter in to the picture at temperatures of $535^{\circ} \mathrm{C}$ or lower. The data obtained at temperatures of $550^{\circ} \mathrm{C}$ and higher were used to plot curves showing the amount of recrystallization as a function of time at constant temperatures (Fig. 26).

Using the isothermal curves of Fig. 26, data were taken to form plots of $\frac{1}{T}$ against the logarithm of the time fbr 50 per cent recrystallization. These data plot linear quite closely, as shown in Fig. 27. This suggests that the rate of recrystallization is conditioned by a single activation energy which may be obtained from the slope of the straight line plot of Fig. 27. If the rate of recrystallization is given by

$$
\frac{-Q}{R T}
$$

Rate $=A e$

$$
\text { where } \begin{aligned}
Q & =\text { activation energy } \\
R & =\text { gas constant } \\
T & =\text { absolute temperature } \\
A & =\text { constant }
\end{aligned}
$$

then

$$
\frac{1}{t}=A^{\prime} e^{-Q / R T}
$$

where $t$ is the time for a given amount of recrystallization to take place at temperature $T$.

then $\frac{d\left(\frac{1}{T}\right)}{d \log t}=R / Q$ which is an expression for the slope of the line in Fig. 27. From the slope of this line, 


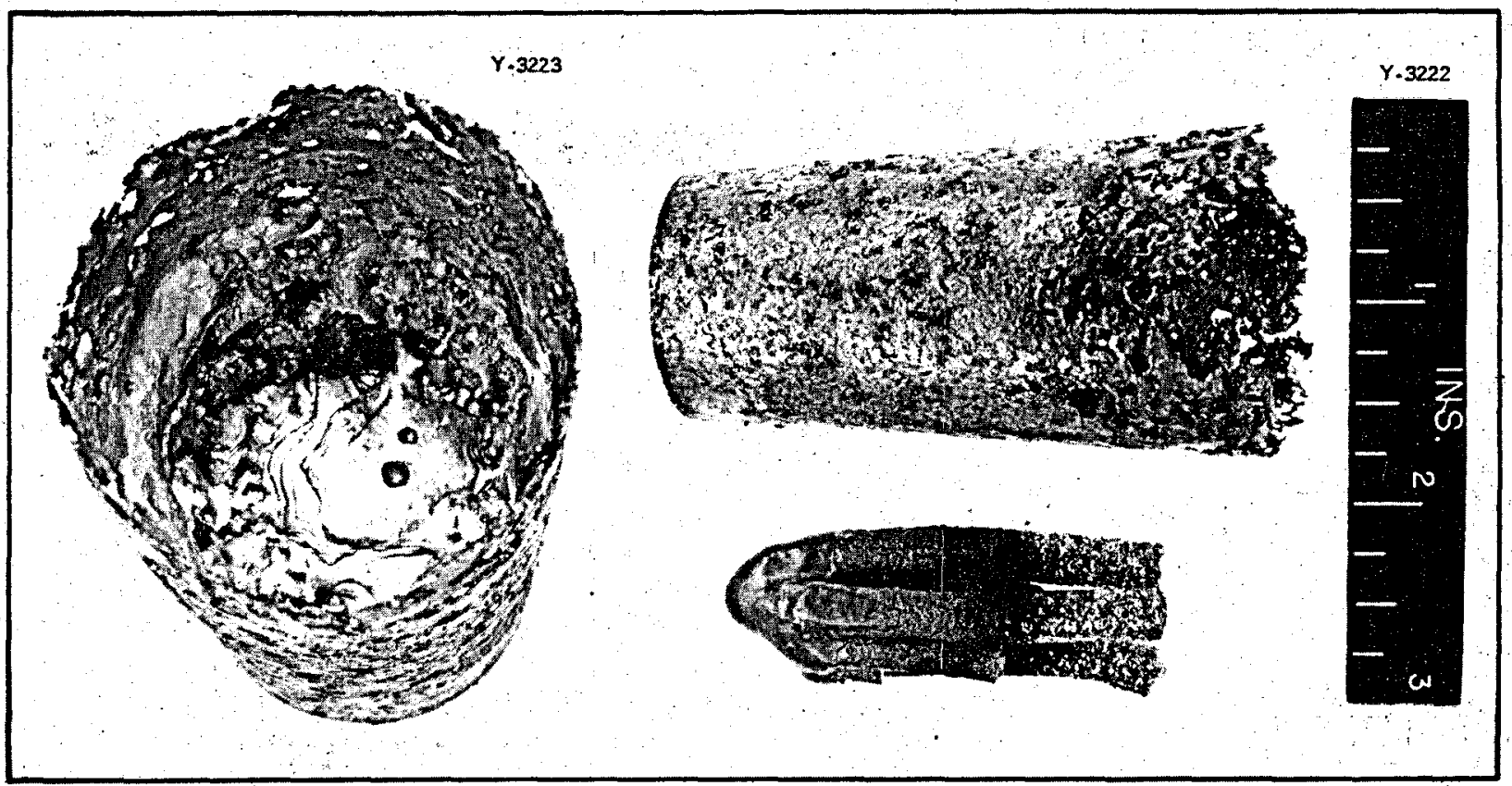

Fig. 19 - Iodide Thorium Melted in Vacuum Arc Furnace.

it was found that the activation energy for recrystallization is $41,900 \mathrm{cal} / \mathrm{mole}$ for the Ames thorium.

Iodide Thorium - Iodide thorium was recrystallized in the same manner as the Ames thorium, and appeared to require slightly higher temperature for recrystallization than the more impare Ames metal.

The hardness of samples of iodide thorium which had been cold-rolled for $80 \%$ reduction remained unchanged after being heated at a temperature of $550^{\circ} \mathrm{C}$ for $1 \mathrm{hr}$. However, the material appeared to be completely recrystallized after being heated at temperatures of $650^{\circ} \mathrm{C}$ and $700^{\circ} \mathrm{C}$ for $10 \mathrm{~min}$. The plot of hardness vs time at temperature for iodide thorium is shown in Fig. 28. Tensile-test specimens of iodide tho- rium which were annealed at $750^{\circ} \mathrm{C}$ for $30 \mathrm{~min}$ had a large grain size, indicating that iodide thorium may have a tendency to grow large grains.

\section{THERMAL CYCLING OF AHES THORIUM IN NaK}

The possibility of using thorium as a structural material in an environment of liquid $\mathrm{NaK}$ at elevated temperatures raised a number of questions which prompted the present work of thermal cycling. The problems of most immediate interest are as follows: (1) Dimensional stability during thermal cycling between $100^{\circ} \mathrm{C}$ and $500^{\circ} \mathrm{C}$; (2) interaction of $\mathrm{NaK}$ and thorium; (3) corrosion of thorium in NaKat $500^{\circ} \mathrm{C}$. Samples were prepared for cycling by extruding, swaging, and rolling Ames thorium into bars $1 / 2$ in. in diameter $x$ in.long. Four different 


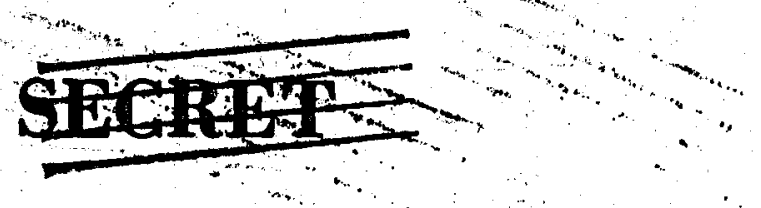

INTER IM REPORT ON METALLURGY OF THORIUM AND THORIUM ALLOYS

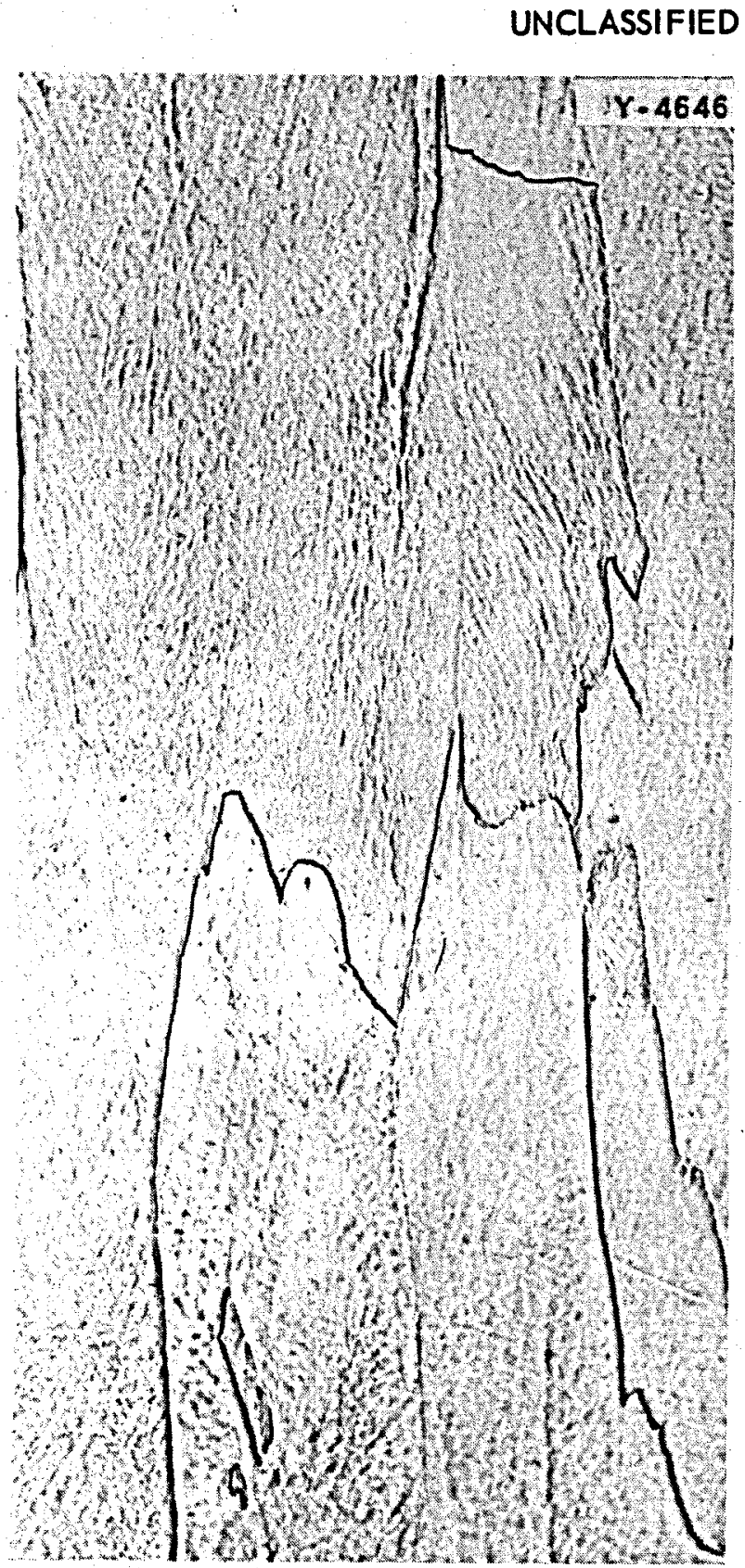

$100 \mathrm{X}$

Iodide thorium, arc-melted, coldrolled into bar, machined into tensile specimen, and annealed $1 / 2$ hr at $750^{\circ} \mathrm{C}$

Fig. 20 - Photomicrograph of ArcMelted Iodide Thorium.

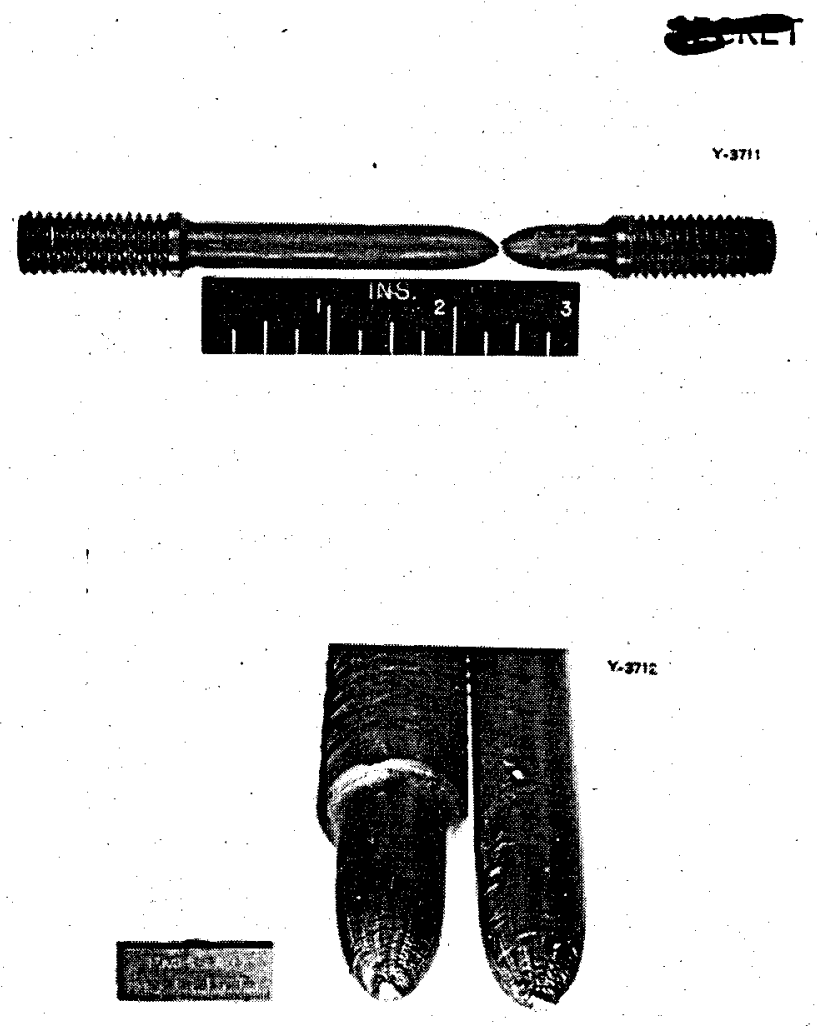

Fig. 21 - Fractured Tensile Specimen of Arc-Melted Iodide Thorium.

types of specimens were used: (1) as extruded, (2) extruded material coldrolled to the proper size bars, (3) extruded material: which was cold-rolled and annealed at $750^{\circ} \mathrm{C}$ for $1 / 2 \mathrm{hr}$, and (4) extruded material cold-swaged to size. Photomicrographs of the various specimens before cycling are shown in Fig. 29.

The specimens of size 4-in. long $x$ $1 / 2$ in. diameter were supported in a stainless steel holder and submerged in liquid $\mathrm{NaK}$ which was contained in a stainless steel tank. The dis as sembled parts of the unit are shown in Fig. 30. A high-frequency induction coil, operated from a $20-\mathrm{kw}, 220-\mathrm{kc}$ Megotherm tube converter, was placed around the steel container. The unit

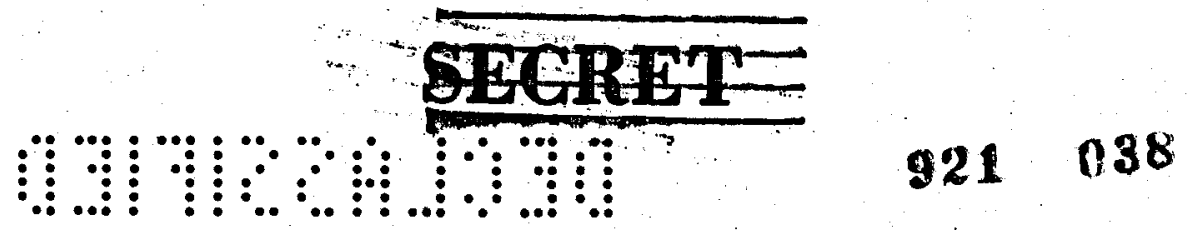




\section{INTER IM REPORT ON METALLURGY OF THORIUM AND THORIUM ALLOYS}

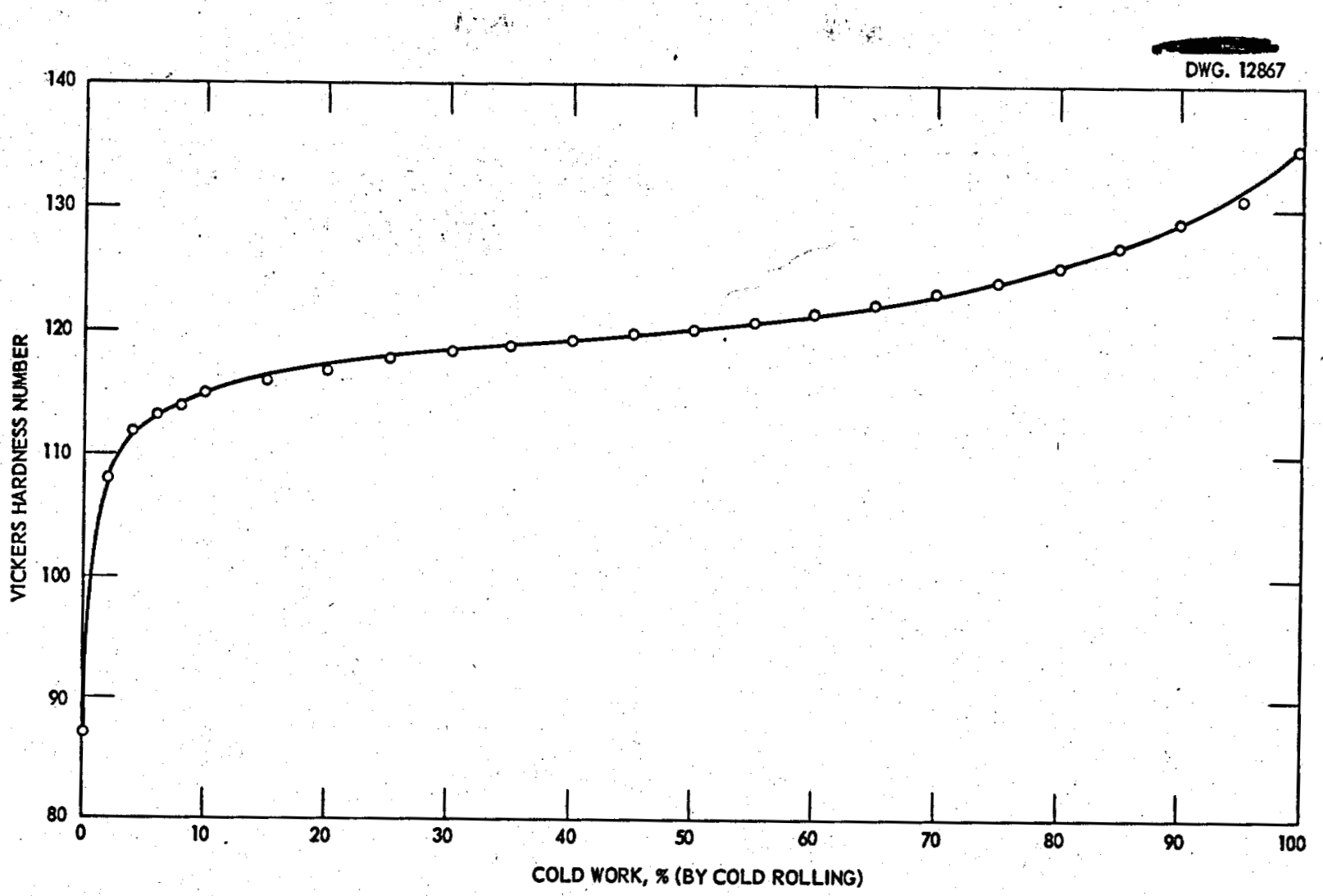

Fig. 22 - Rate of Work-Hardening of Ames Thorium.

is equipped with a Brown recorder controller which heats the entire, assembly to $500^{\circ} \mathrm{C}$ and holds the temperature constant for 15 min to insure uniform specimen temperature. At the end of the holding period, the induction heating unit is atomatically turned of $f$ and air jets are turned on to accelerate cooling to $100^{\circ} \mathrm{C}$, at which temperature the air jets are interrupted and the power applied to reheat the container. Since this method requires that the liquid metal and container be heated and cooled as well as the test specimens, a relatively slow rate of cycling is obtained with essentially no temperature gradient in the specimen. The heating period requires about $10 \mathrm{~min}$ and the cooling time is about 11 min so that approximately 40 cycles are obtained per 24-hr day. The complete experimental setup is shown in Fig. 31 . The specimens were measured in all dimensions with micrometer calipers and weighed prior to cycling. The $\mathrm{N}_{\mathrm{a}} \mathrm{K}$ was placed in the outer container under a cover of kerosene. The rack containing the specimens was placed in the $\mathrm{NaK}$ and the top plate secured. The first heating cycle distills off the kerosene which is collected in a flask. An inert atmosphere was maintained over the bath of NaK at all times. Purified 


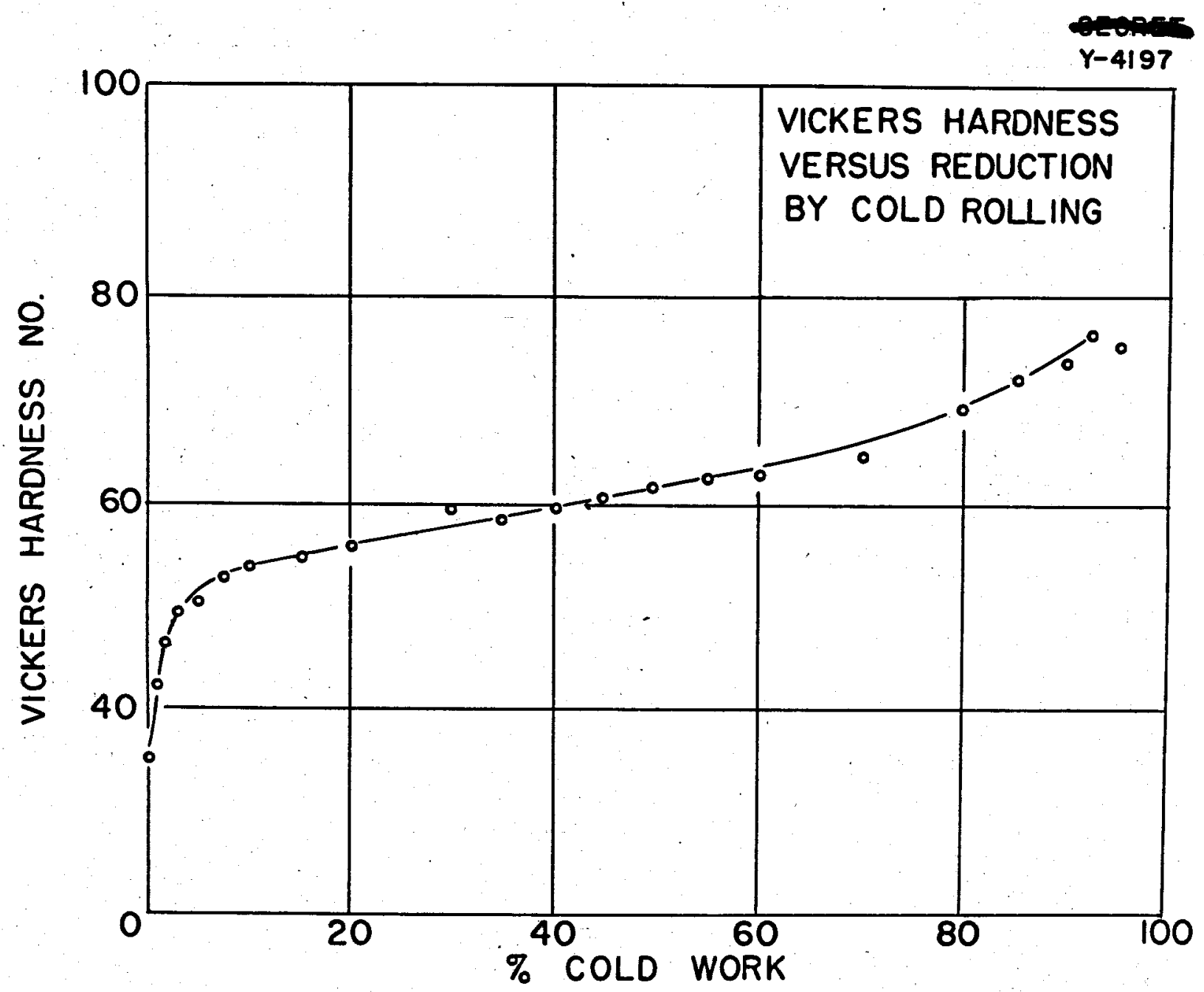

Fig. 23 - Work-Hardening Curve for High-Purity Iodide Thorium.

argon or helium was introduced through one top port and taken out at another and passed.through an oil bubbler. The samples were removed after each 100 cycles and inspected for warpage, cracking, weight changes, growth, and corrosion.

It found that all of the thorium specimens suffered a weight loss dur- ing the cycling. A scale formed on the specimens and became progressively heavier as cycling was continued. At the end of 400 cycles, some of this scale was removed for identification. It was proven, by X-ray and chemical analysis, to be pure thorium dioxide. Since the $\mathrm{NaK}$ which was charged into the furnace had not been purified, it apparently was contaminated with oxygen and was scavenged by the thorium

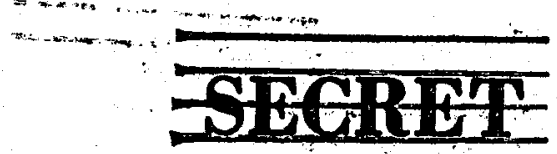




\section{INTERIM REPORT ON METALLURGY OF THORIUM AND THORIUM ALLOYS}

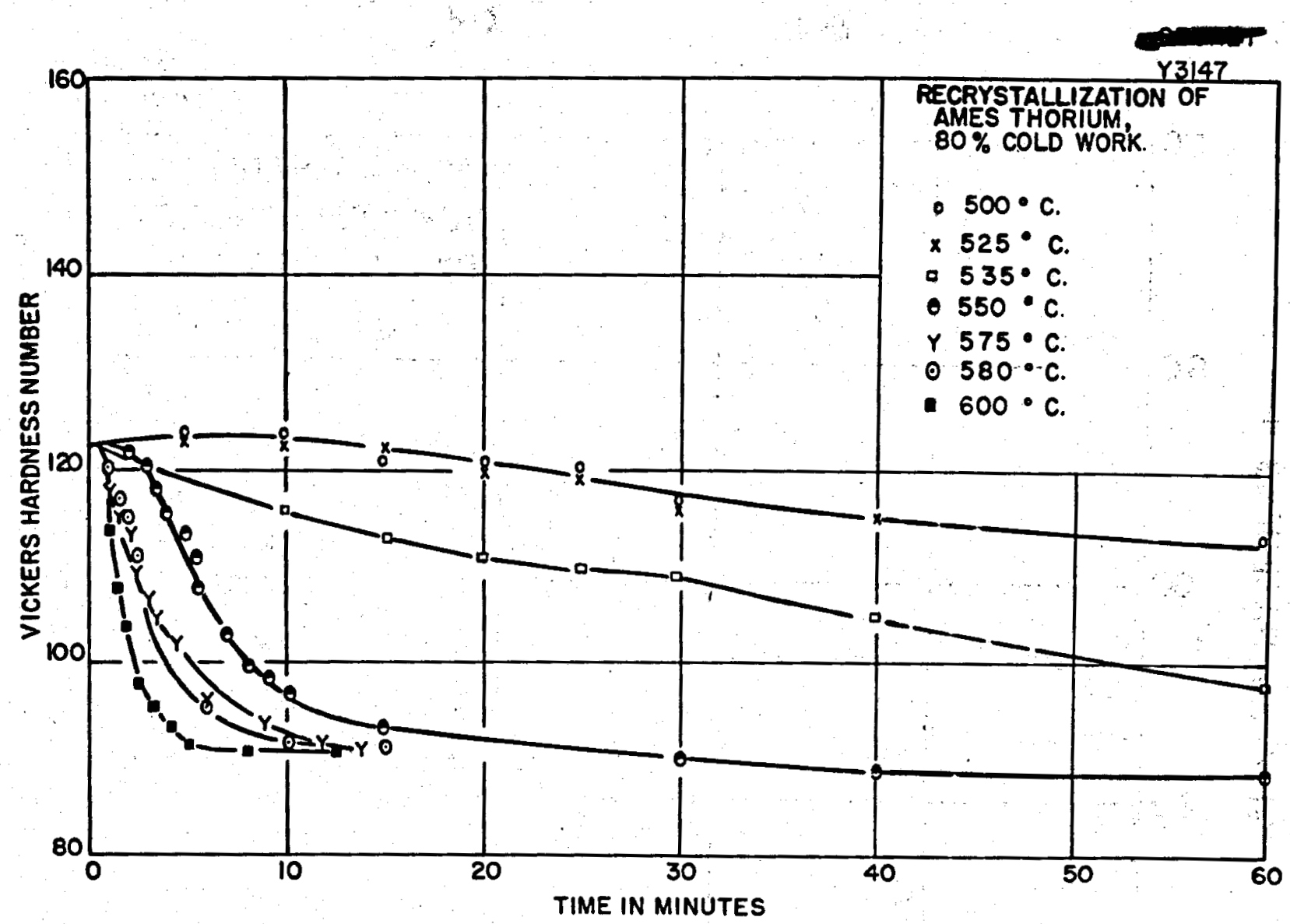

Fig. 24 - Recrystallization Curves for Ames Thorium.

specimens. This established the desirability of using purified NaK when needed as a coolant for thorium. The cold-rolled thorium slugs and the annealed thorium slugs showed no deformation after 100 cycles between $100^{\circ} \mathrm{C}$ and $500^{\circ} \mathrm{C}$. The only changes of dimensions were very minor, and may be attributed to the oxide scale formed on the specimen which often spalled off, leaving bar slightly smaller in diameter than the original. The weight loss was fairly consistent, and after 400 cycles the rate of weight loss was much higher than during the first 400 cycles. The data are given in Table 1 in Appendix I. The coldswaged and as-extruded thorium slugs were slightly bowed after 1000 cycles. There were probably some residual stresses in the metal, due to the mode of deformation, which were relaxed by the cyclic heat treatment. From this very preliminary data, there are indications that some warping or bending of worked thorium bars may occur depending upon the method of fabri. cation.

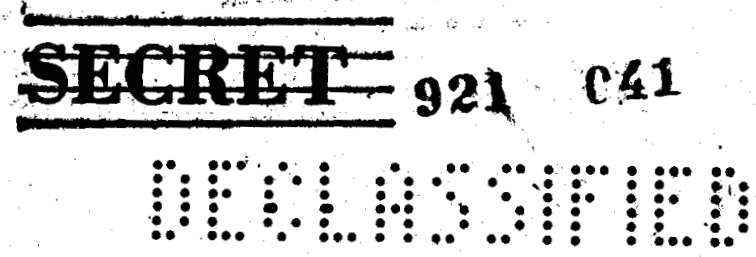




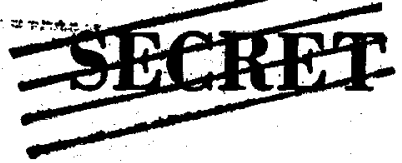

INTER IM REPORT ON METALLURGY OF THORIUM AND THORIUM ALLOYS

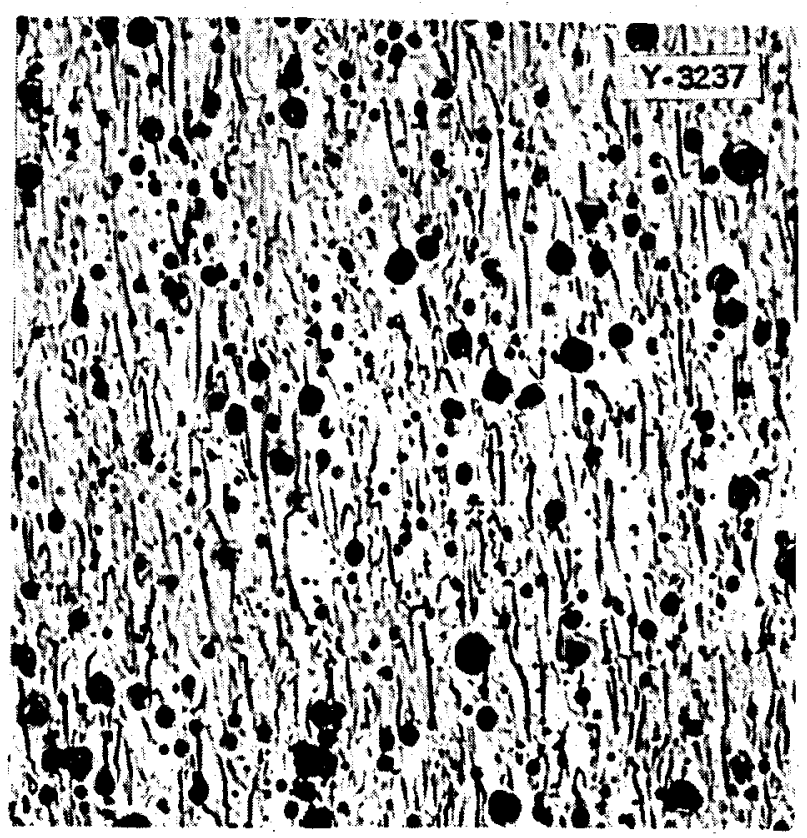

a - Ames thorium, cold-worked for $80 \%$ reduction by cold-rolling

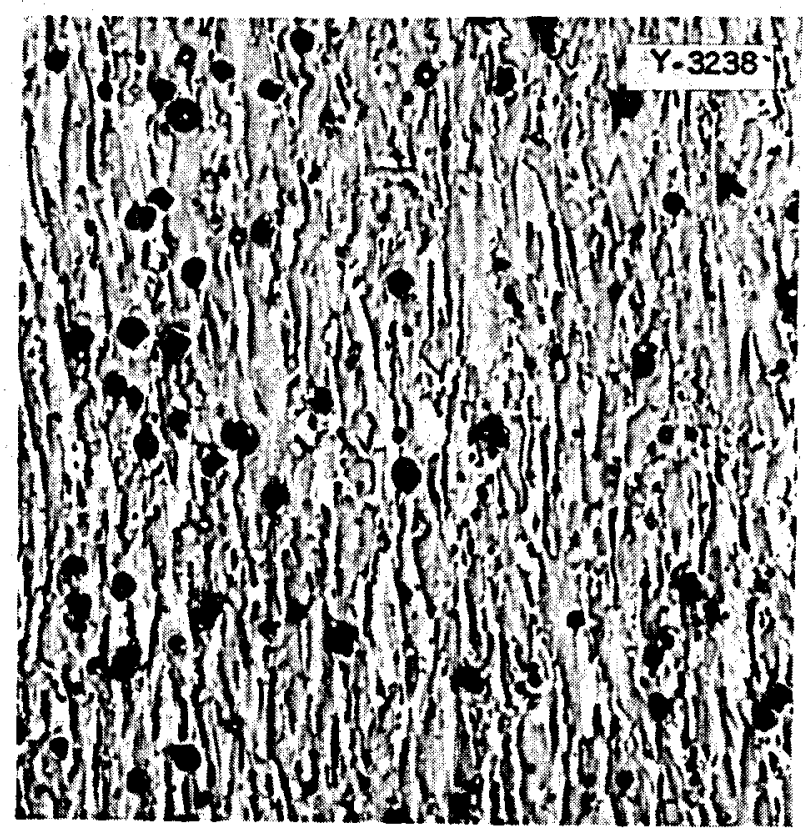

b - Ames thorium, $80 \%$ cold-worked, heat-treated at $550^{\circ} \mathrm{C}$ for $3 \mathrm{~min}$
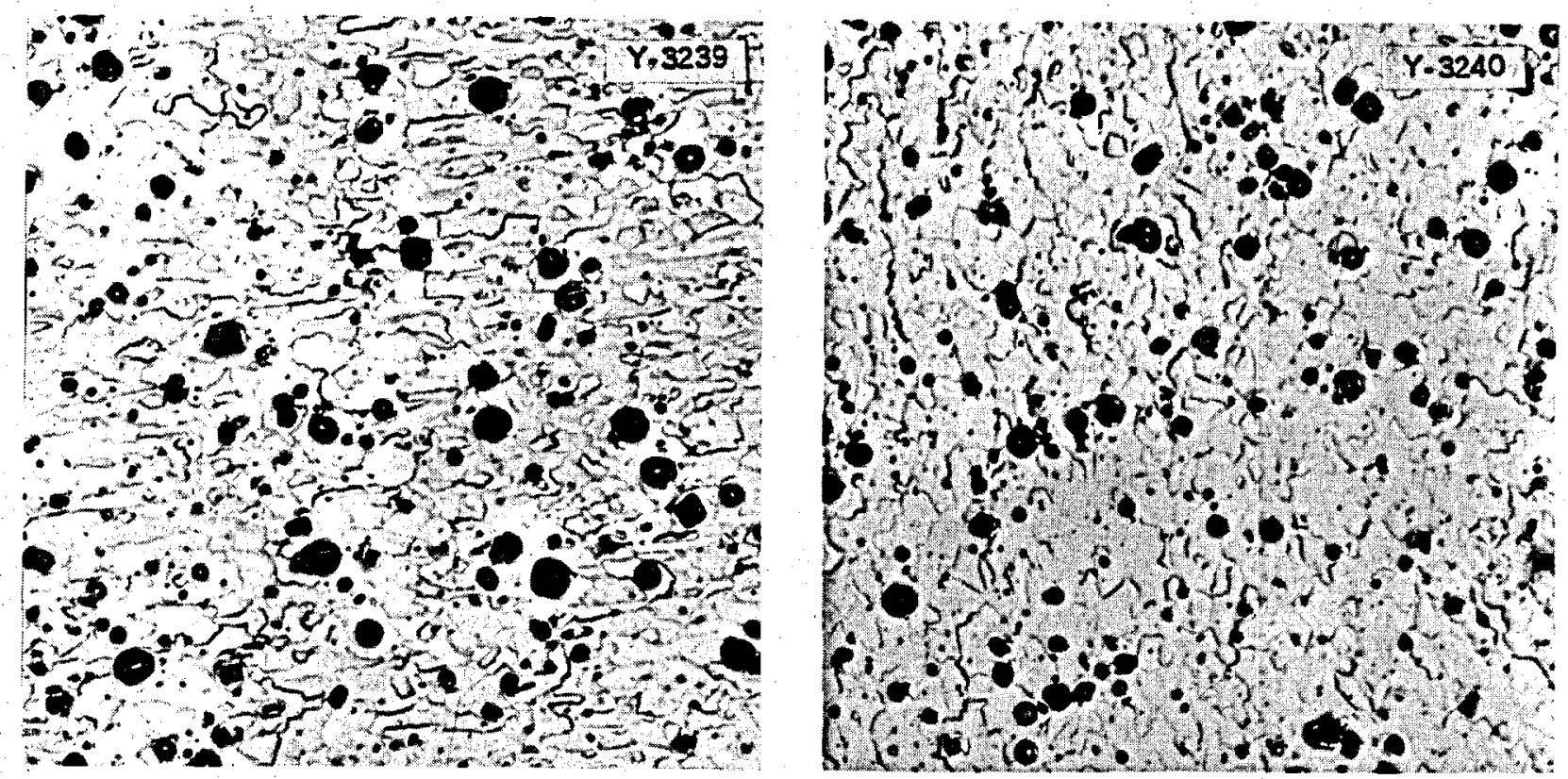

c - Ames thorium, $80 \%$ cold-worked, heat-treated at $550^{\circ} \mathrm{C}$ for 9 min

d - Ames thorium, $80 \%$ cold-worked, heat-treated at $550^{\circ} \mathrm{C}$ for $60 \mathrm{~min}$

Fig. 25 - Photomicrographs of cotu-Worked and Heat-Treated imes Thorium. 


\section{INTERIM REPORT ON METALLURGY OF THOR IUM AND THORIUM ALLOYS}

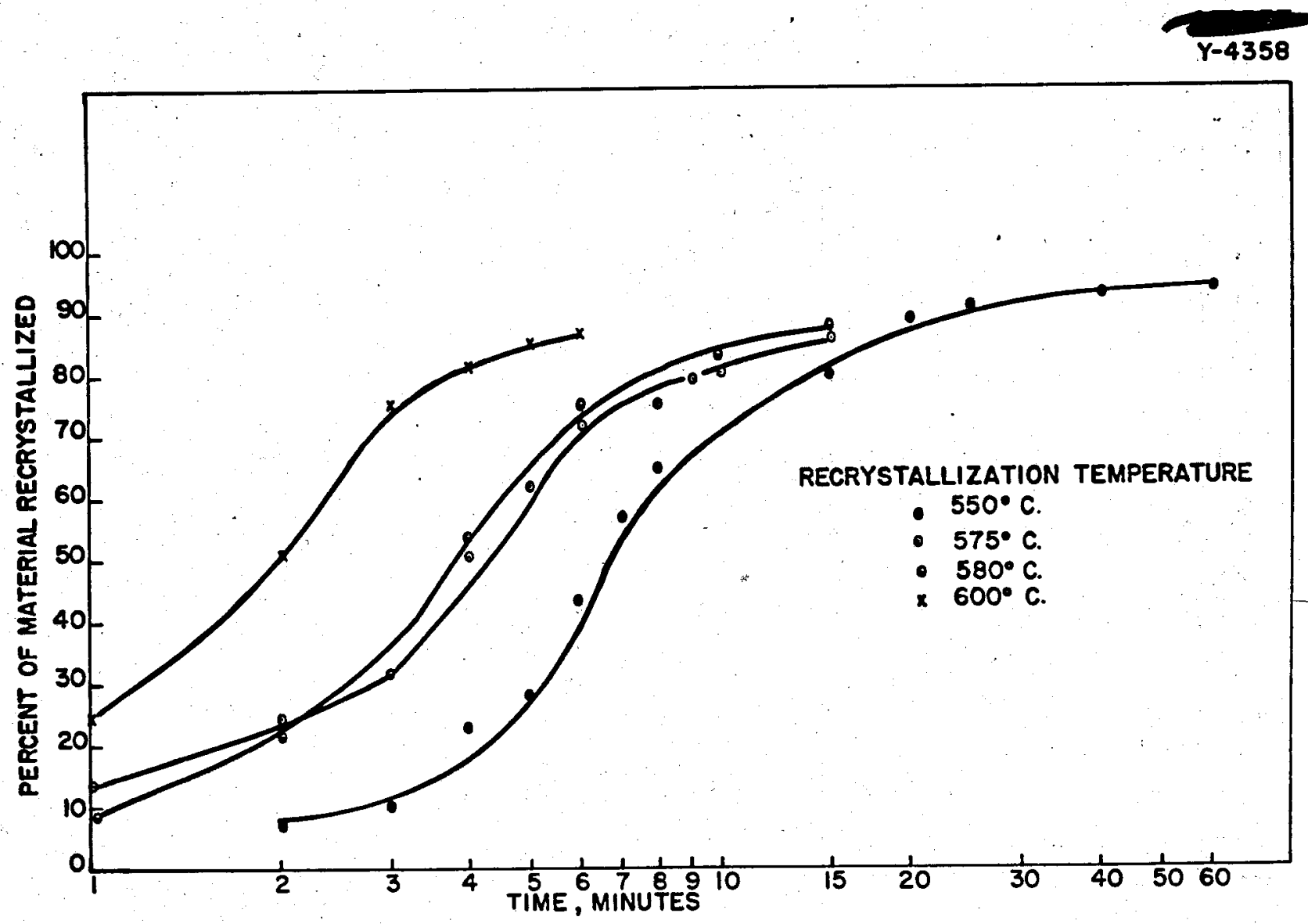

Fig. 26 - Isothermal Recrystallization Curves of Ames Thorium.

The bars after having been cycled for 1000 cycles are shown in Fig. 32 . The bars were sectioned for metallographic study, and it was found that the oxidation had penetrated the annealed samples (Figs. 33 a and 33 b) until there were some oxide particles at the center of the bar. The outer surface, to a depth of about one quarter of the diameter of the bar, appeared to be a continuous phase which was shown to be an oxide. When spectrographic analysis failed to show any composition gradient from the outer surface to the center of the specimen, a gas analysis was made in the follow- ing manner: A sample of the complete cross-section containing the parent metal in the center and the second phase in the outer surface was analyzed for oxygen and found to contain from 0.5 to $1 \% \mathrm{O}_{2}$ by wt. A second sample was prepared by drilling a 1/4-in. hole through the center of the bar to remove the section $r i c h$ in thorium and leaving the portion rich in the unidentified second phase. Again the oxygen content was very high $(0.5$ to $1 \% \mathrm{O}_{2}$ by wt). A third sample was prepared by removing the surface of the bar, leaving a rod from the center section of the original bar where the

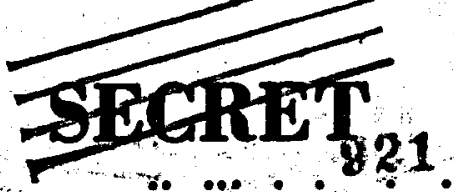




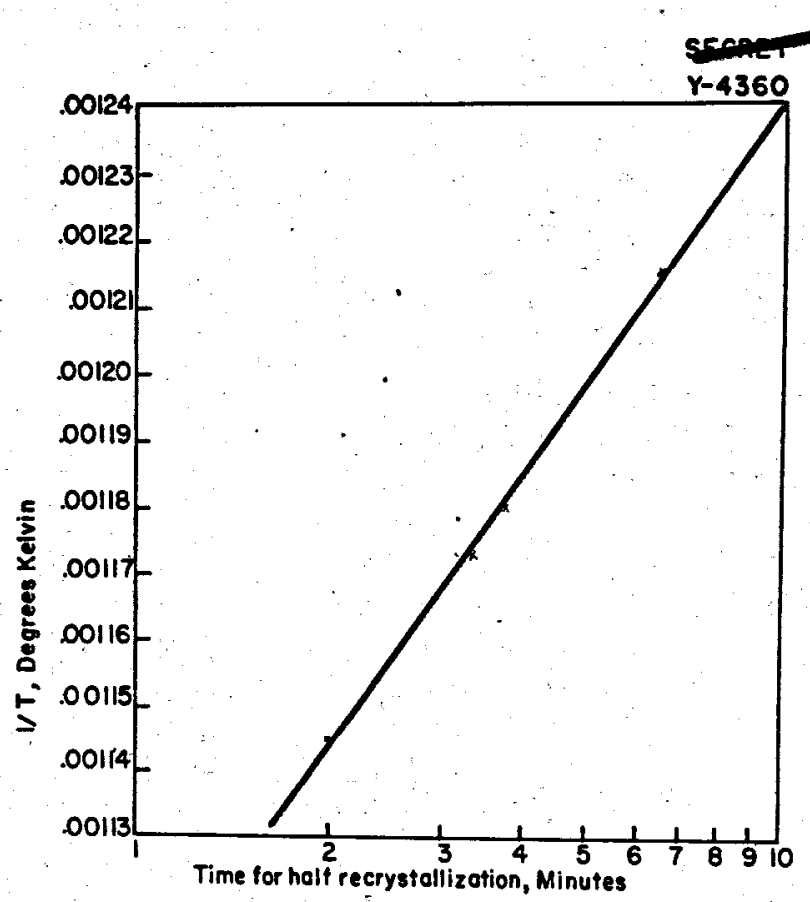

Fig. 27 - Reciprocal of Absolute Temperature vs Time for Half Recrystallization in Ames Thorium.

concentration of the second phase was low. The oxygen content of this specimen was found to be comparatively low $\left(0.014 \% 0_{2}\right.$ by wt), showing that the second phase must be an oxide phase.

The same type of oxide penetration was found in all of the thorium specimens as shown in Figs. 33b-33d.

\section{FABR ICATION}

General - Since thorium metal is quite soft, having diamond pyramid Vickers hardness numbers of 36 to 85 depending upon the purity, it may be cold-worked readily. Rolling may be performed satisfactorily at room temperature. The work-hardening characteristics of pure thorium permit coldrolling to foil 0.001 in. thick or

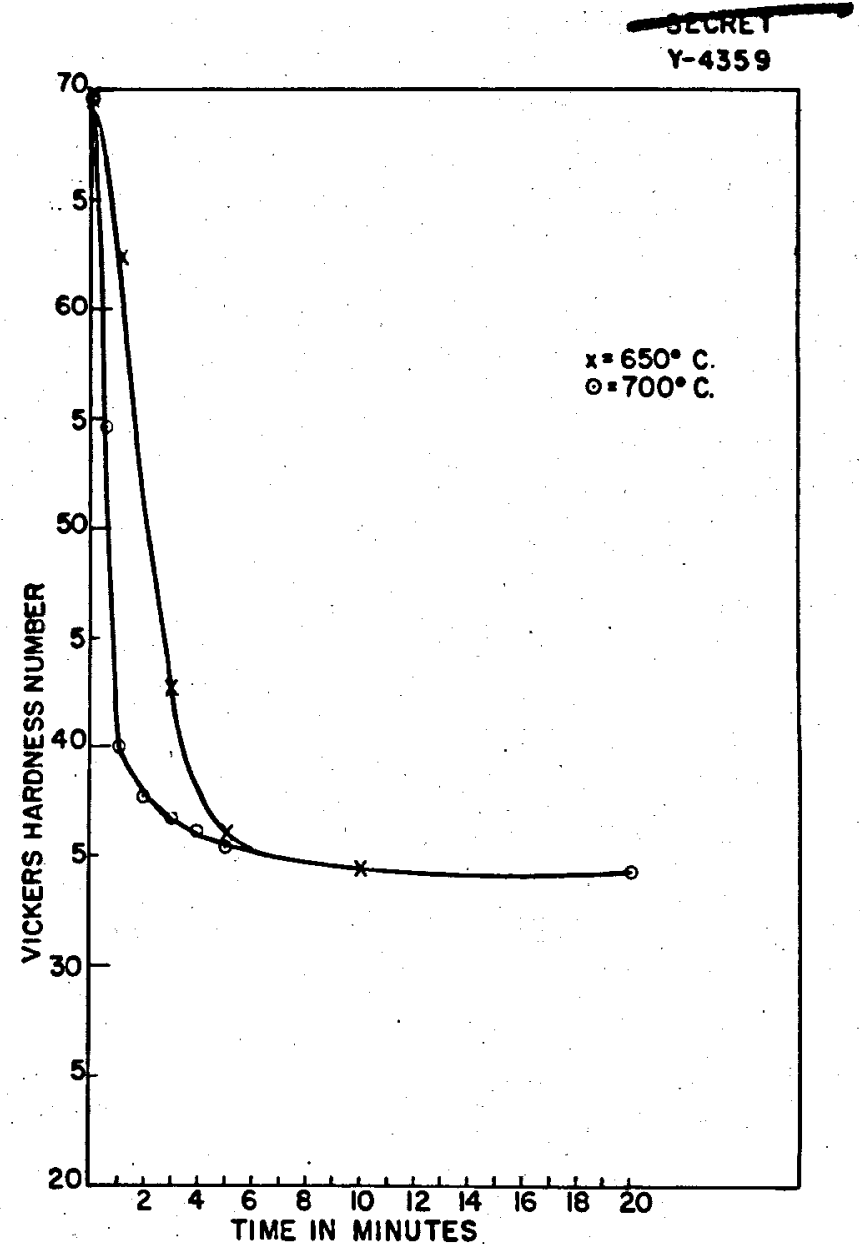

Fig. 28 - Recrystallization. of Iodide Thorium, $80 \%$. Cold Work.

approximately $99.9 \%$ reduction without intermediate annealing and without appreciable cracking. When thorium is cold-rolled, no protective canning is required, since only a superficial film of oxide is formed during rolling. However, if thorium is rolled at elevated temperatures above $700^{\circ} \mathrm{C}$, some protection is needed to prevent oxidation. The other alternative is to allow surface oxidation and after completion of working remove the oxidized layer by pickling. 


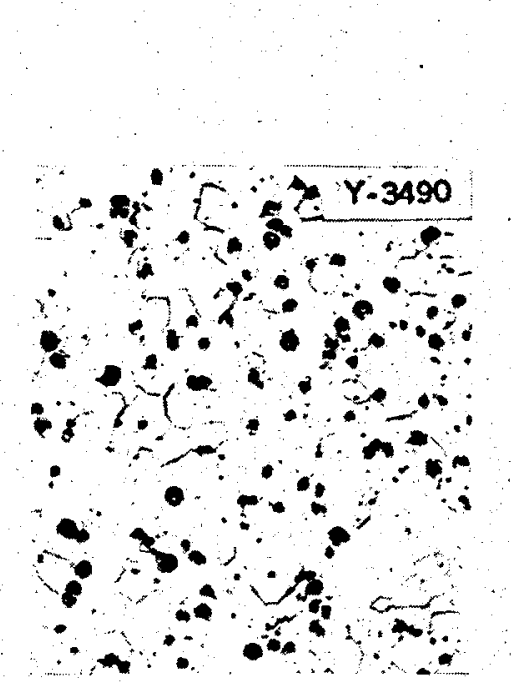

\section{3)}

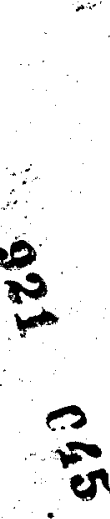
a Transverse
section

Ames thorium extruded, cold-rolled, and annealed at $750^{\circ} \mathrm{C}$ for $1 / 2 \mathrm{hr}$

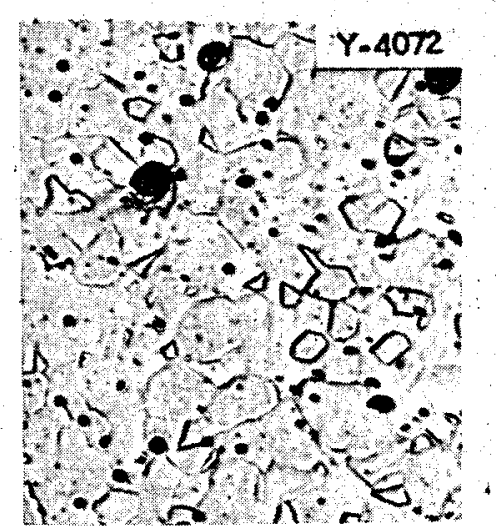

$$
\begin{gathered}
\text { e - Transverse } \\
\text { section }
\end{gathered}
$$

Ames thorium extruded into $3 / 4-i n$-dia. rod at

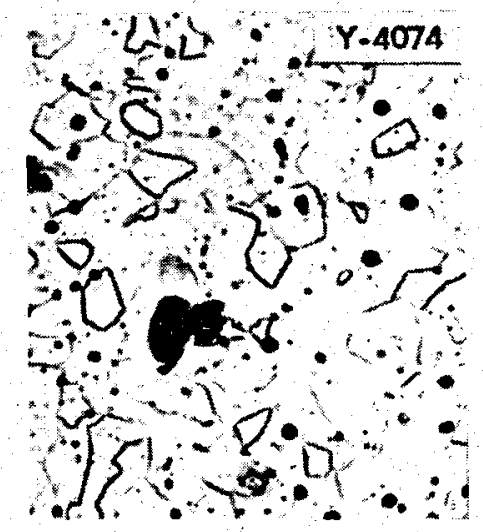

Transverse
section

Ames thorium as extruded at $850^{\circ} \mathrm{C}$
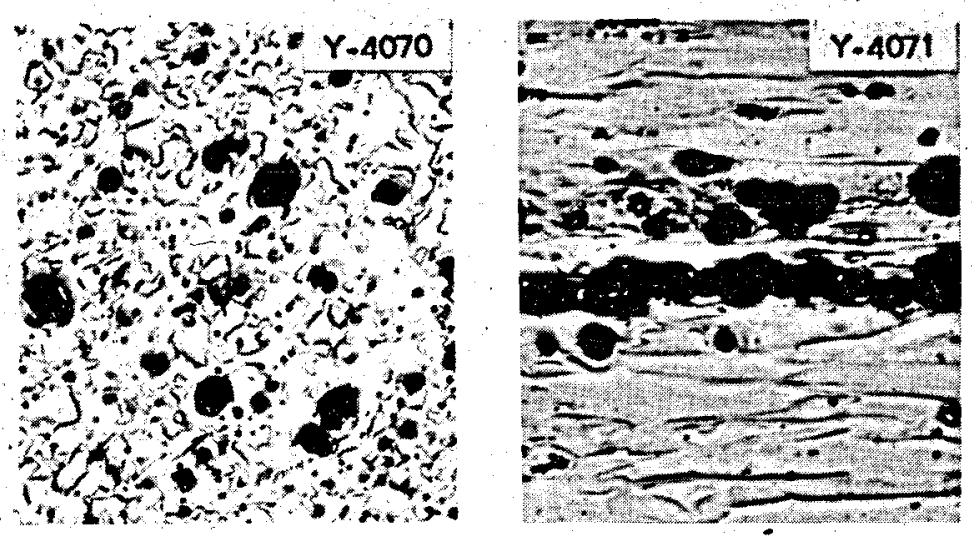

\section{$g$ - Transverse}

$$
\text { section }
$$

\section{h - Longitudinal} section

Ames thorium extruded into $/ /$-in.-dia rod at $825^{\circ} \mathrm{C}$ and cold-rolled to $1 / 2$-in.-dia rod 


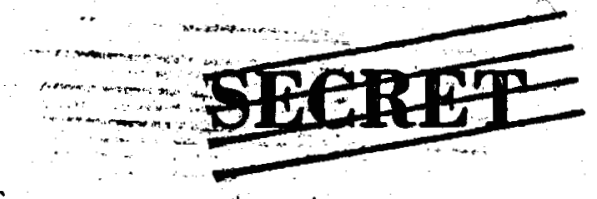

INTERIM REPORT ON METALLURGY OF THORIUM AND THORIUM ALLOYS

UNCLASSIFIED

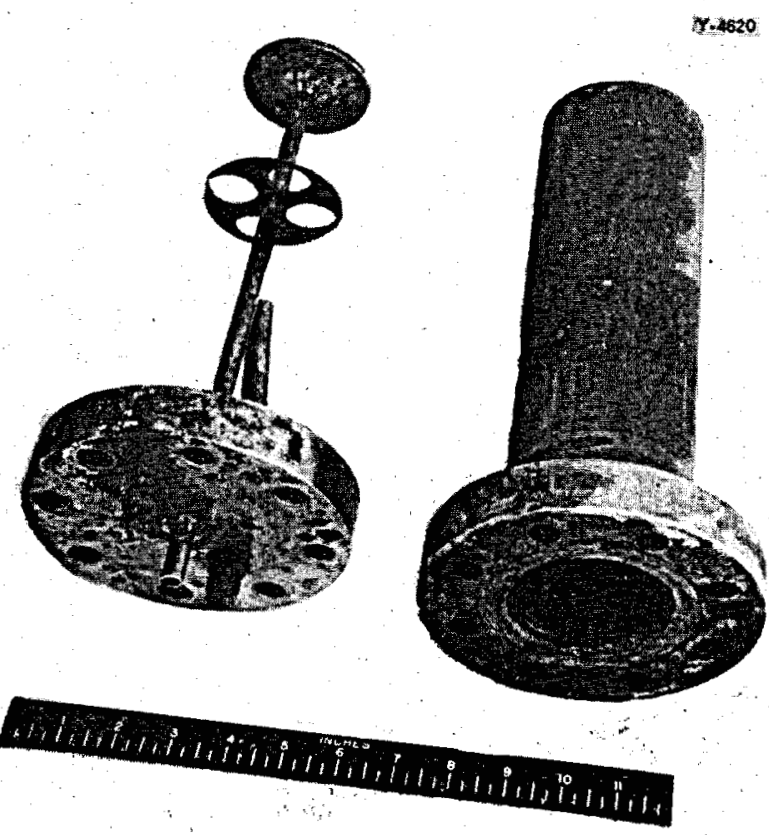

F16. 30 - Disassembled Parts of container for Thermal cycline of Thorium tn Nak.

Some thorium has been extruded by heating billets in a protective at mosphere and transferring the billet to the container of the extrusion press in air. The billet was coated with a protective layer of graphitesodium silicate paste. Although it was impossible to examine the hot billets carefully, apparently there was no oxidation.-

Extrusion - The extrusion of thorium has been investigated for the production of rods, flat bars, and tubing in rarious sizes. The quality of the extrusions has been evaluated as functions of extrusion temperature, extrusion rate, reduction ratio, die design, and lubrication. The initial evaluation consisted of a visual inspection of the surface quality of of the extrusions, and by this criterion all of the extrusions have
UNCLASSIFIED

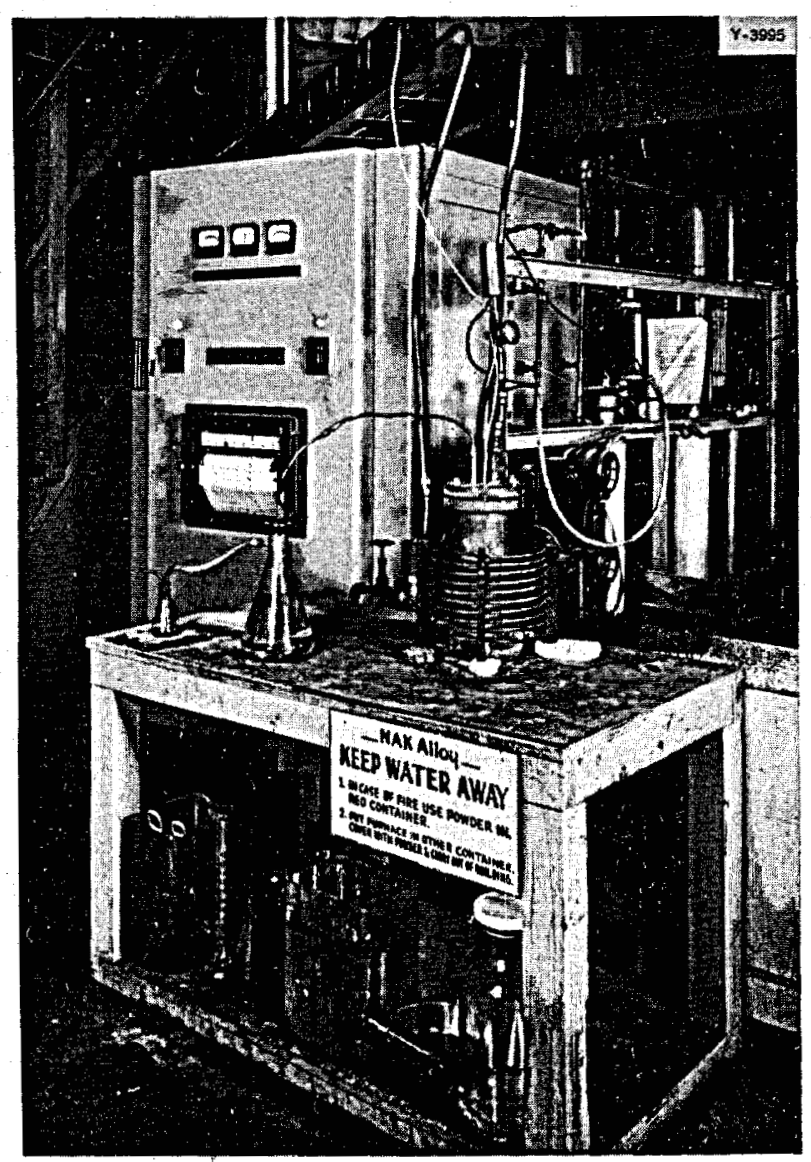

F1g. 31 - Experimental Setup for Cycling Samples in Nak.

produced relatively good material. Samples were taken from each extrusion for tensile-test and creep-test specimens. Samples were taken at various positions along the length of the extrusion for chemical analysis and for metallographic examination. When it was possible, all variables except those under consideration were maintained constant while normal extrusion procedure was followed as outlined below.

The cast thorium billets were machined to the proper size for extrusion and heated in a salt bath 


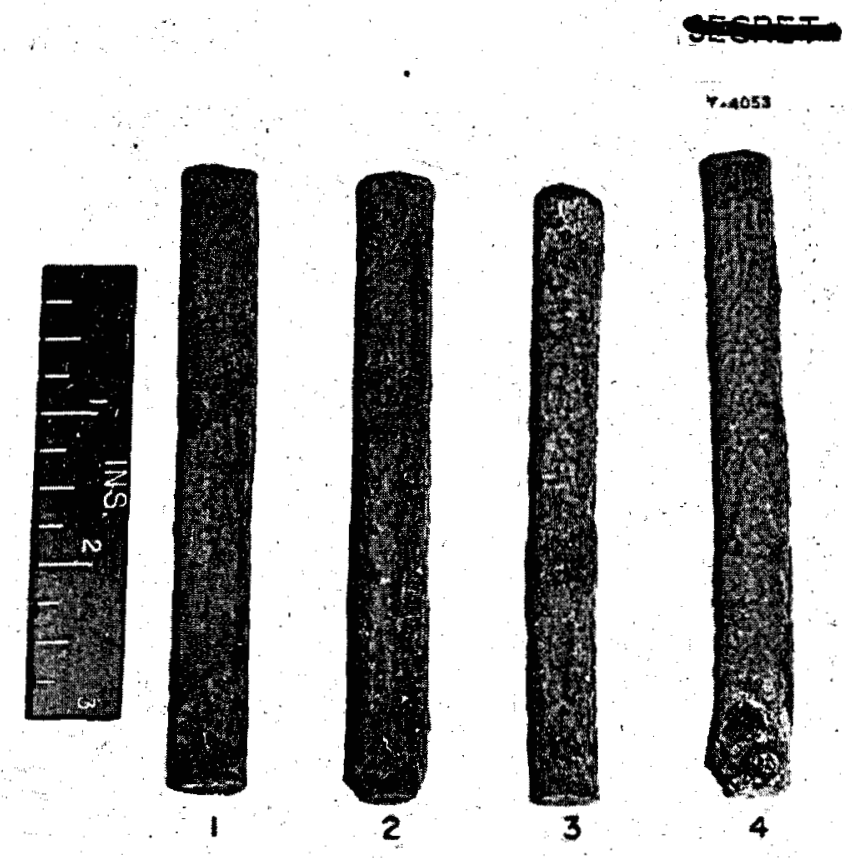

Fig. 32 - Thorium Bars After 1000 Cycles.

(Houghton's Liquid Heat ND) for approximately $1 \mathrm{hr}$. The billets were bare, and the salt served as protection from oxidation as well as a heating medium. A thin layer of salt adheres to the surface of the billet as it is manually transferred from the salt bath to the container of the extrusion press. The 700-ton Lake Erie extrusion press used for this experimental work is shown in Fig. 34. Two containers were avalable for the work; one 3 in. in diameter and 16 in long, the other 4 in. in diameter and 16 in. long. The smaller container was used for the major portion of the extrusion work. After the billet had been inserted into the heated container, graphite dummy block was placed behind the billet to remove the end of the extrusion from the die. A steel dumm block followed the graphite and the entire assembly was pushed with the ram.
A water-quenching $j$ ig was added to the press to quench the hot extruded rod or tubing as it leaves the die in order to prevent excessive oxidation. Figure 35 shows the $j i g$, which consists of two concentric pipes. welded together to form an annulus which supplies high-pressure water through $1 / 8$ in. diameter holes in the inner pipe to quench the extrusion. The jig is bolted to the back of the die holder in order to begin quenching the extrusion approximately 18 in. behind the die.

When tubing is to be extruded, a hollow billet is prepared that fits loosely over a floating mandrel The mandrel is slightly tapered to facilitate removal from the finished tube. The mandrel extends through the die opening, leaving an annular space for the extrusion of tube. A billet prepared for extrusion is shown with a mandrel in Fig. 36. The preheated billet is placed over the mandrel before insertion into the press container. The extrusion is carried out in the same manner as with solid billets. A complete record of the extrusions is shown in Table 2 in Appendix 1 .

The variables investigated for extrusion of Ames thorium are discussed individually below.

Billet Temperature-- The billet temperature was varied from $950^{\circ} \mathrm{C}$ down to $700^{\circ} \mathrm{C}$ in $50^{\circ} \mathrm{C}$ increments. There was no visual difference in the surface of the 1 -in. rods extruded in this temperature range. However, the graphite dumy block has a greater tendency, to feed into the extruded rod during the $700^{\circ} \mathrm{C}$ extrusion. Lowertemperature extrusions were not attempted due to this tendency, and 


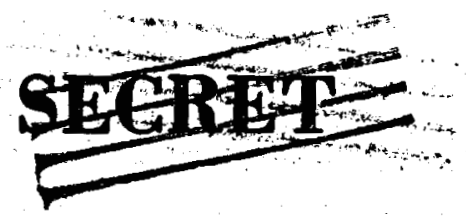

INTERIM REPORT ON METALLURGY OF THORIUM AND THORIUM ALLOYS

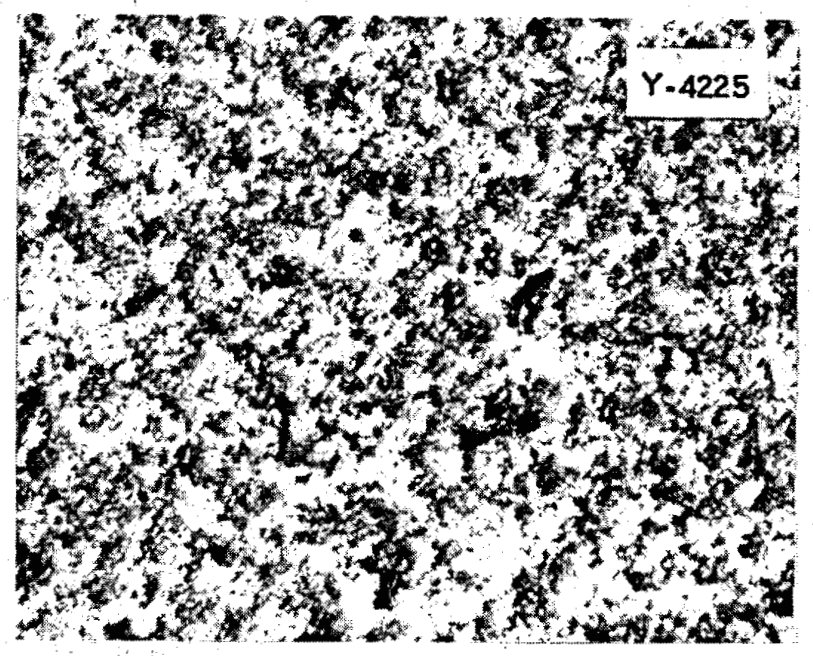

Transverse section

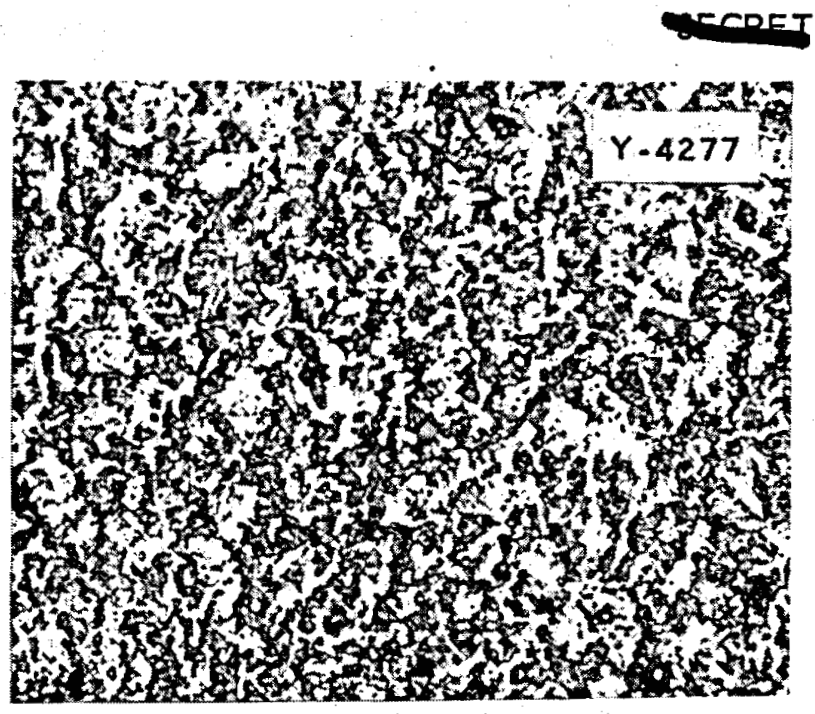

Longitudinal section

Fig. 33a - Ames Thorium Extruded, Cold-Rolled, Annealed $/ 2$ hr at $750^{\circ} \mathrm{C}$, Cycled for 1000 Cycles Between $100^{\circ} \mathrm{C}$ and $500^{\circ} \mathrm{C}$ in Nak.

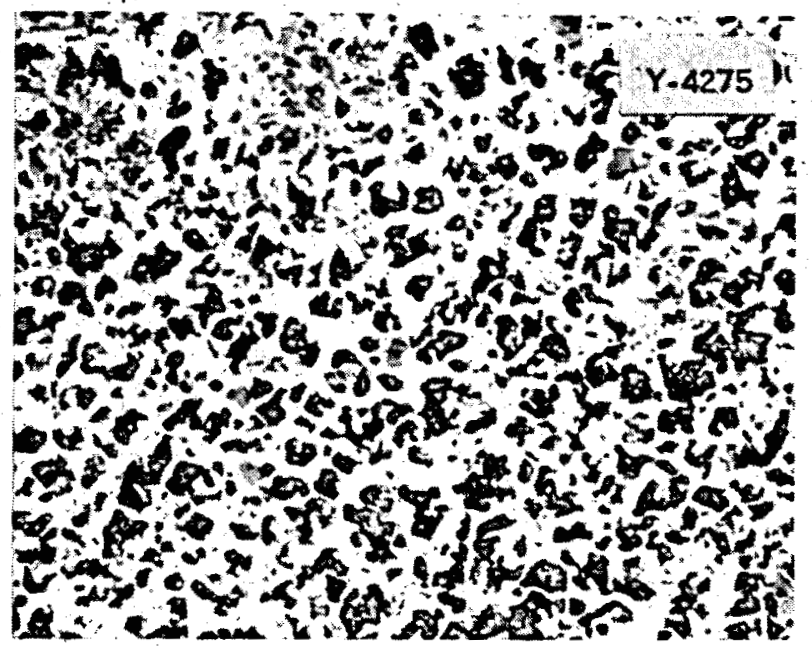

Transverse section

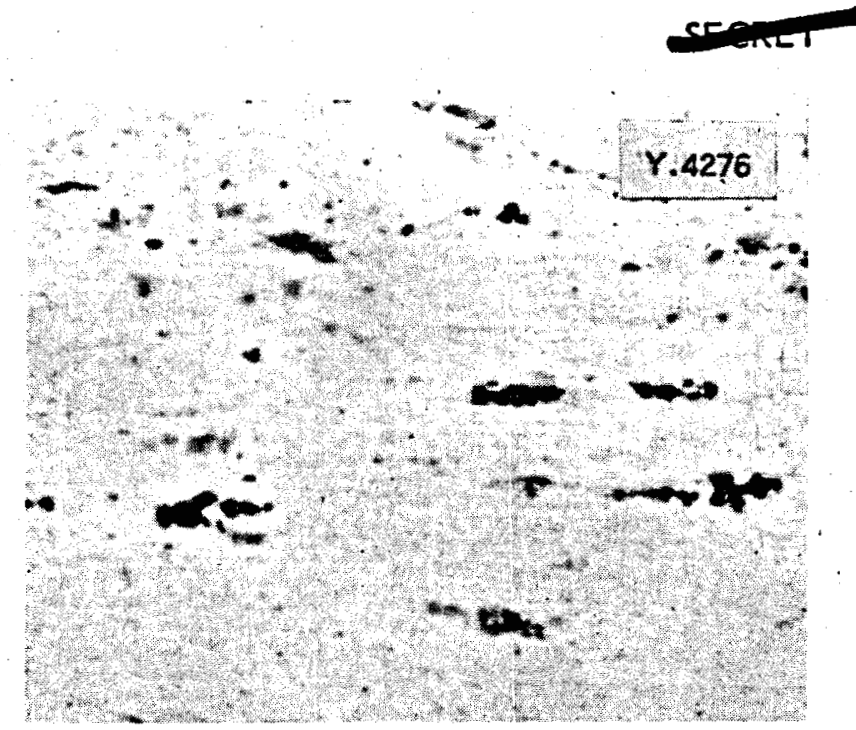

Longitudinal section

Fig. 33b - Ames Thoriun Extraded at $850^{\circ} \mathrm{C}$ and Cycled for 1000 Cycles Between $100^{\circ} \mathrm{C}$ and $500^{\circ} \mathrm{C}$ in NaK.

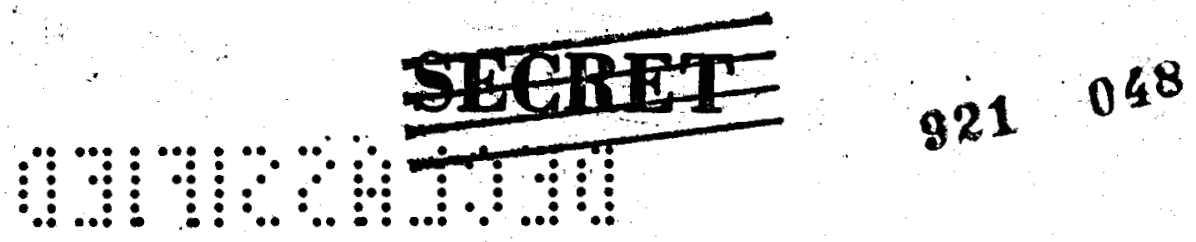




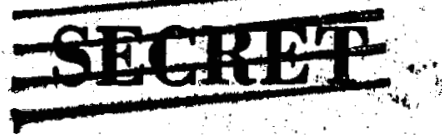

\section{INTERIM REPORT ON METALLURGY OF THOR IUM AND THORIUM ALLOYS}

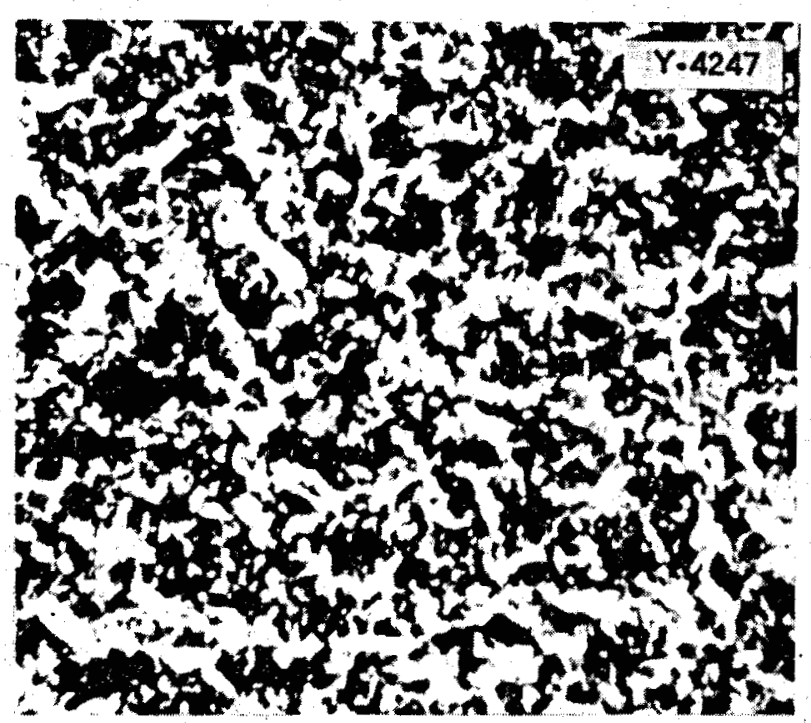

Transverse section

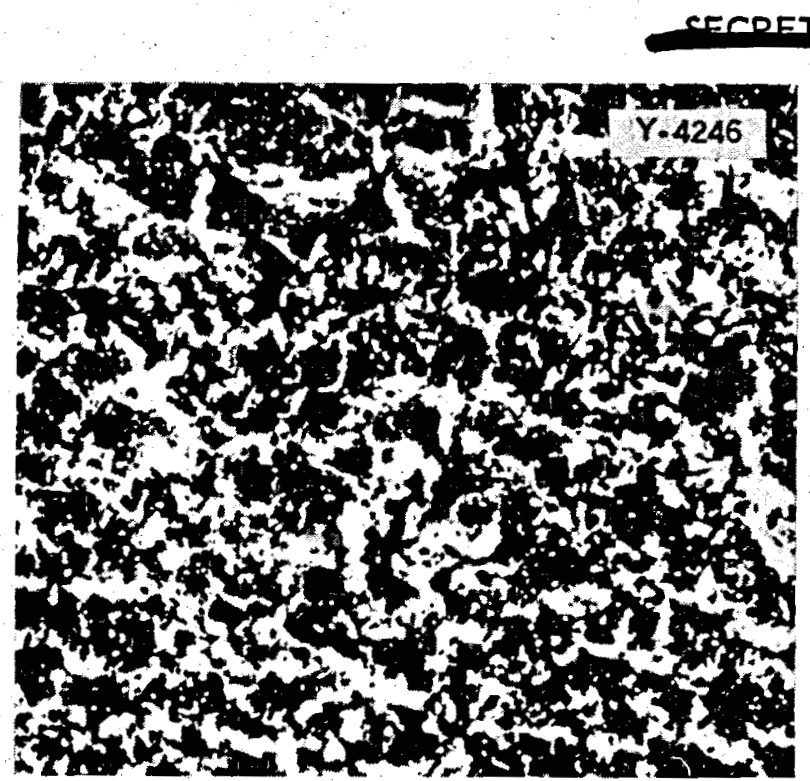

Longitudinal section

Fig. 33c - Ames Thorium Extruded into to $1 / 2$-in.-dia Rod, and Thermally cycled for 1000 Cycles Between $100^{\circ} \mathrm{C}$ and $500^{\circ} \mathrm{C}$ in Nak.

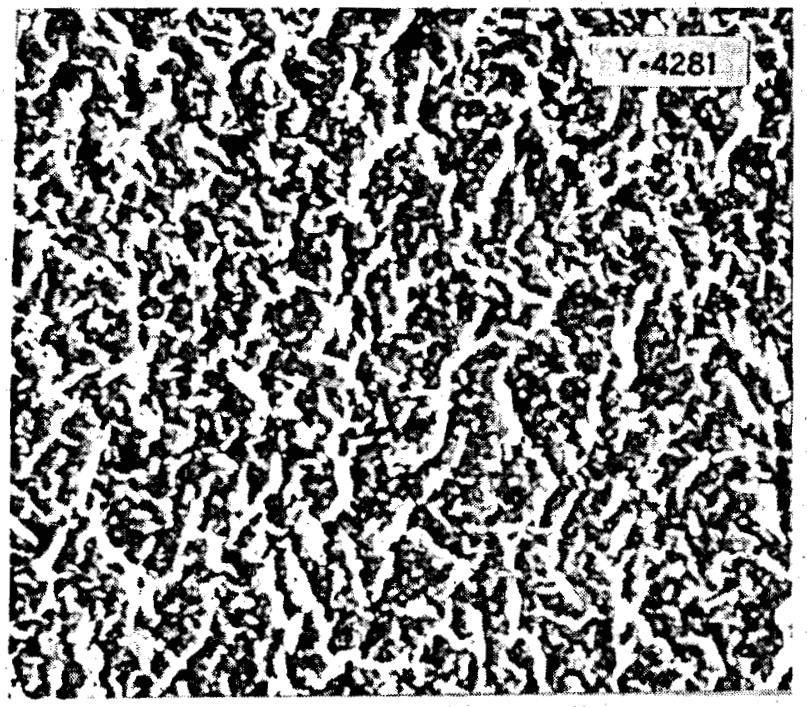

Transverse section

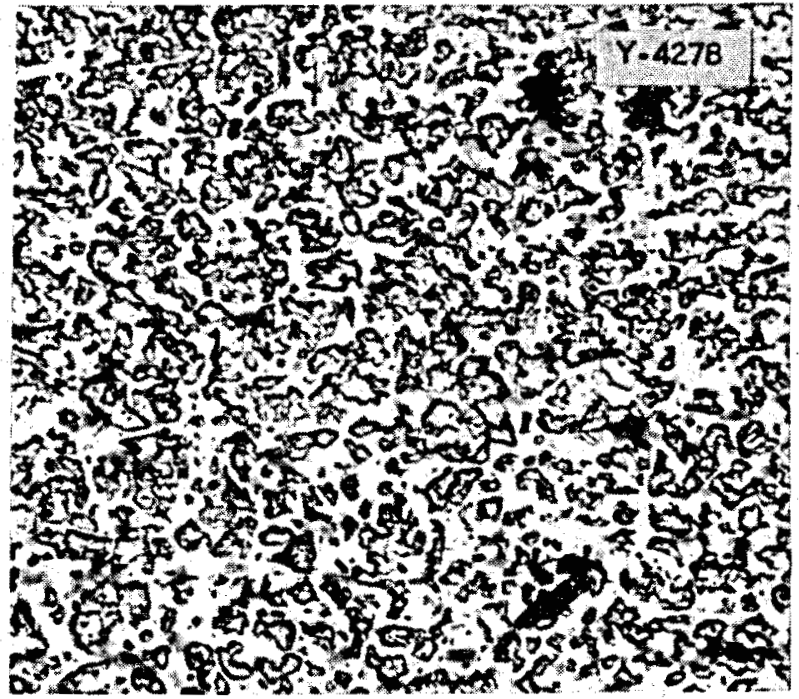

Longitudinal section

Fig. 33d - Ames Thorium Extruded into $z_{-i n}-\mathrm{dia}$ Bod at $825^{\circ} \mathrm{C}$, Cold-rolled to $/ 2$-in.-dia Rod, and Thermally Cycled for 1000 Cycles Between $100^{\circ} \mathrm{C}$ and $500^{\circ} \mathrm{C}$ in NaK.

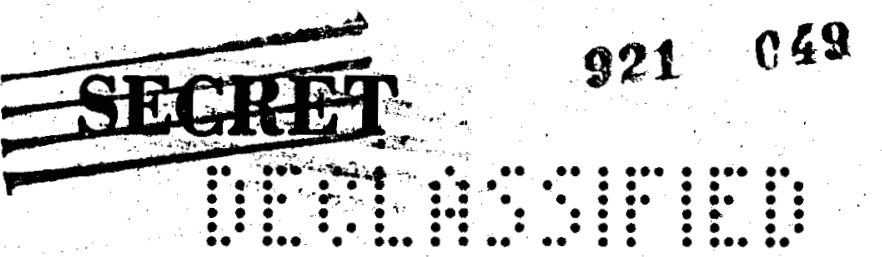


:....:

¿...:

.......

....:.:

$\because$

$\because \because$

$\because \because \because$

$\because 01 d$

$\because$ tat

$\because$ SP

¿..

$\therefore . .0$ $\left|\begin{array}{l}4 \\ 17\end{array}\right|$

$\ln _{10}^{\infty}$

42

量
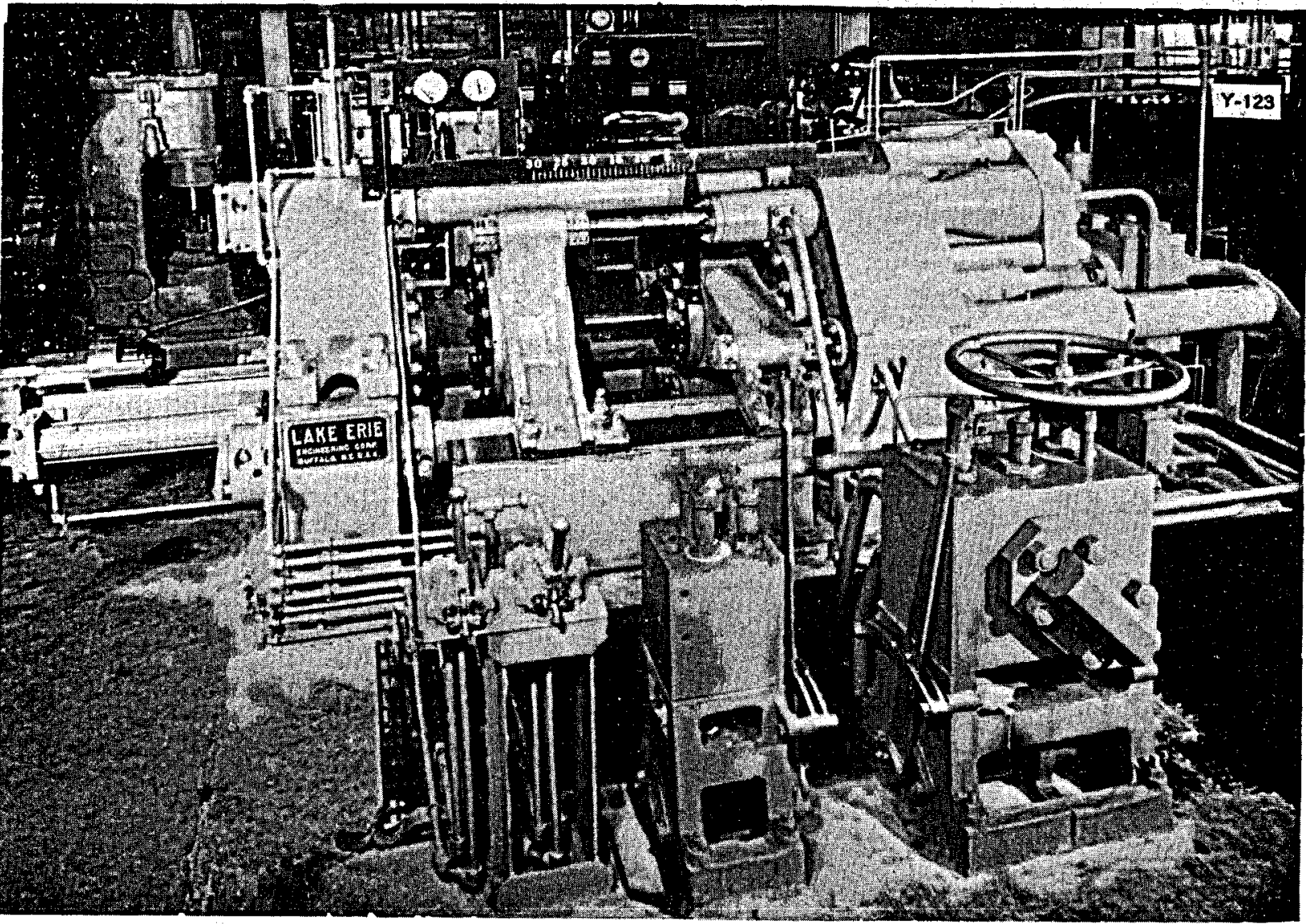

en

Fig. 34 - 700-Ton Lake Erie Extrusion Press. 


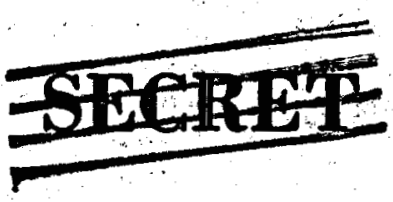

INTERIM REPORT ON METALLURGY OF THORIUM AND THORIUM ALLOYS UNCLASSIFIED UNCLASSIFIED

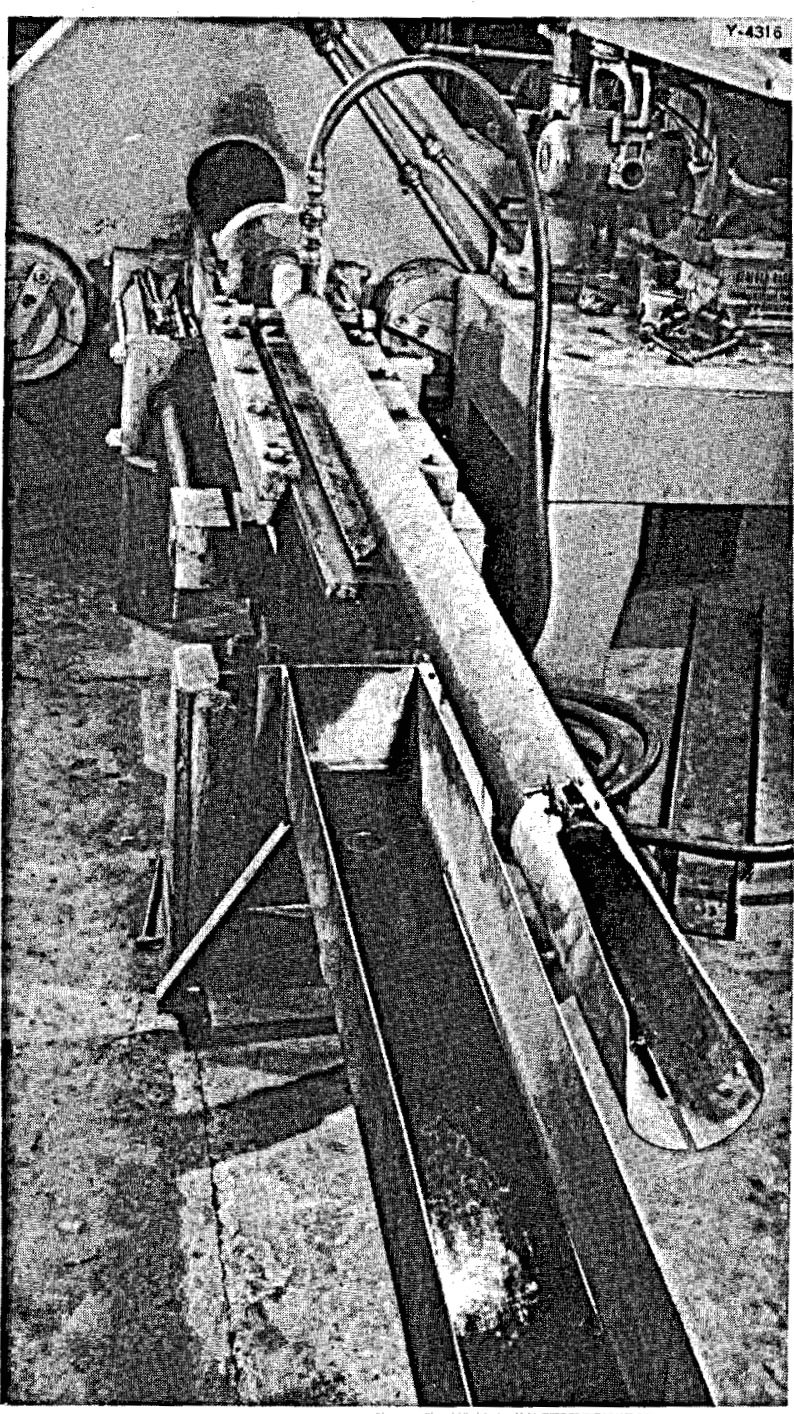

Fig. 35 - Quenching Jig on Extrusion Press.

also because the press was operating at near its maximum pressure capacity. It is planned to extend the work to higher temperatures, probably $1000^{\circ} \mathrm{C}$ and $1100^{\circ} \mathrm{C}$.

Extrusion rate - The effect of extrusion rate was investigated by extruding 1 -in.-diameter rods at speeds varying from about $4 \mathrm{ft} / \mathrm{min}$ to 450

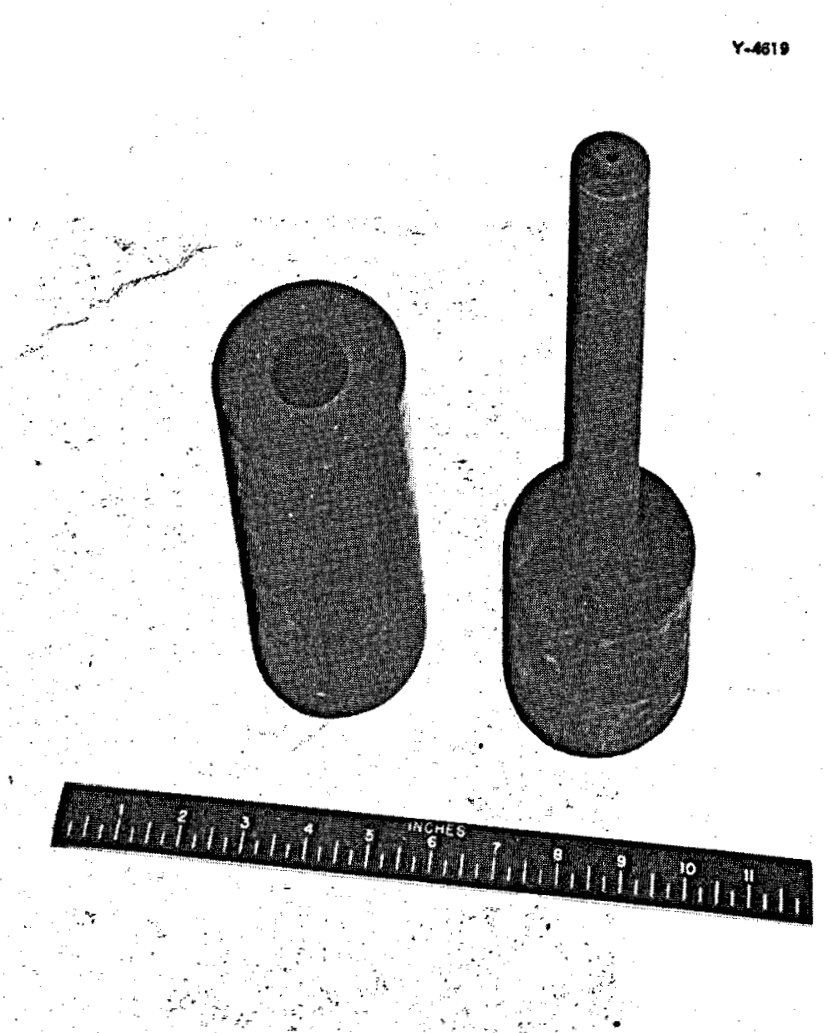

Fig. 36 - Billet of Ames Thorium Prepared for Tubing Extrusion.

ft/min. There was no apparent difference in the quality of extrusion over the entire range of rates. A speed of about $50 \mathrm{ft} / \mathrm{min}$ was adopted for the remainder of the extrusion work because it was a convenient speed and allowed a suitable period of time for water-quenching the extrusion.

Reduction Ratio - The effect of reduction ratio has been investigated by extruding billets 3 and 4 in. in diameter into rods and tubing of various sizes The reduction ratios varied from $2.5 / 1$ to $36 / 1$, and a 11 extrusions produced rods with a good surface quality. Since this was the only criterion at this stage, it was concluded that the quality of extrusion 


\section{INTER IM REPORT ON METALLURTTOF THORIUM AND THORIUM ALLOYS}

is independent of reduction ratio within the range investigated.

Lubrication - Various lubricants have been used in the extrusion of thorium. Glasses with low melting points have been used, but proved to be unsuccessful because of chilling during extrusion and then scoring the surface and giving an unsatisfactory surface in general. Lampblack and machine oil lubricant was tried, but improved results were obtained by substitution of beeswax for the oil. Later, the practice of mixing flake graphite and sodium silicate to form a thick paste, which was applied to the cold stem and die, gave much better results. This lubricant was used for the latest extrusions.

Die Design-Prior experience, along with the ease of fabrication and availability of flat-faced dies, dictated their use for most of the early work on extrusion. These dies were either made from a solid steel forging or contained an insert in the nose of the die to take the wear during extrusion. Dies of the insert type are being used to investigate the effect of die design, since the inserts are relatively cheap from the standpoint of fabrication, and aterial that is satisfactory for the die body does not appear to offer a satisfactory working surface. The working part of the die, made of a suitable material and to a desired shape, is inserted in the nose of the die body. Variations of the shear type die are being studied by using various shapes of bell die inserts. One such die, having $30^{\circ}$ face angle with a $1 / 2$-in. throat radius and $1 / 4-i n$. bearing, produced an excellent tube. A longitudinal section of this extrusion along with

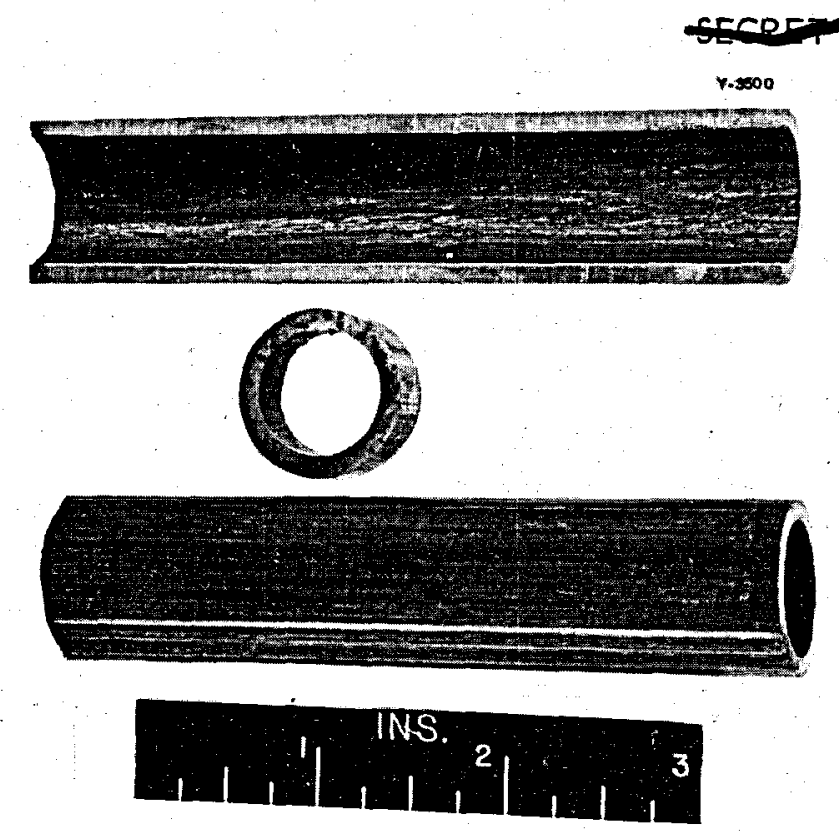

Fig. 37-Tubing Extruded from Ames Thor ium.

a piece of the tubing produced is shown in Fig. 37 .

Die and Mandrel Material - Die and mandrel material present the greatest problem at the present. The normal hot-work die steels such as AlleghenyLudlum's Potomac, Latrobe's C.H.W. and L.P.D., and Braebum's T-Alloy have not made one extrusion without cracking. This problem is complicated by the peculiar flow of thorium during extrusion. It was found on the first extrusions that the metal flowed across the face of the flat-faced shear-type die, rather than flowing through the billet as is the case in most other metals. This type of flow lends itself to a bell-type die somewhat better than with the shear-type die, due tothe erosion of the shape orifice at the entrance of the throat in a shear die. The erosion experienced during the test of some die materials has been sufficient to produce a resemblance of a bell die in a shear 


\section{INTERIM REPORT ON METALLURGY "UF" THORIUM AND THORIUM ALLOYS}

die. However, bell dies of some materials have been unsuccessful. In the case of one hot-work die steel, the throat of the die was washed out and the die diameter made considerably larger.

Flow lines observed on the die face were the first indication of this flow across the face of the die, and in order to prove the point, a billet was partially extruded and sectioned to study the flow characteristics. The removed portion was approximately 6 in long, and, as may be seen in Fig. 38 , the partial extrusion indicates that the billet as a whole moves down the container and most of the flow occurs in the vicinity of the die. This indicates that the hot metal has a relatively high shear resistance, since the billet slides through the container to a greater extent than most metals. Because of this erosion, insert dies were made of a Stellitetype material and a high cobalt 18-4-1 steel. Both of these materials appear to withstand the erosion equally well. However, they are both quite susceptible to cracking. Some of the Stellitetype (Doss Steel Research Company No. 3130 alloy) inserts have cracked considerably during the first extrusion. Modifications of these two materials are being investigated in an attempt to find a tough material sufficiently hard to withstand the erosion. Experience with the mandrels is about the same as with the dies. The steel mandrel becomes soft, and in the case of one stem $3 / 8-i n$. in diameter, it actually failed in tension. A Stellitetype (Doss Steel Hesearch Company No. 2115 alloy) failed with arittle fracture on the first extrusion.

Extrusion cladding of Thorium - In many applications, thorium metal would

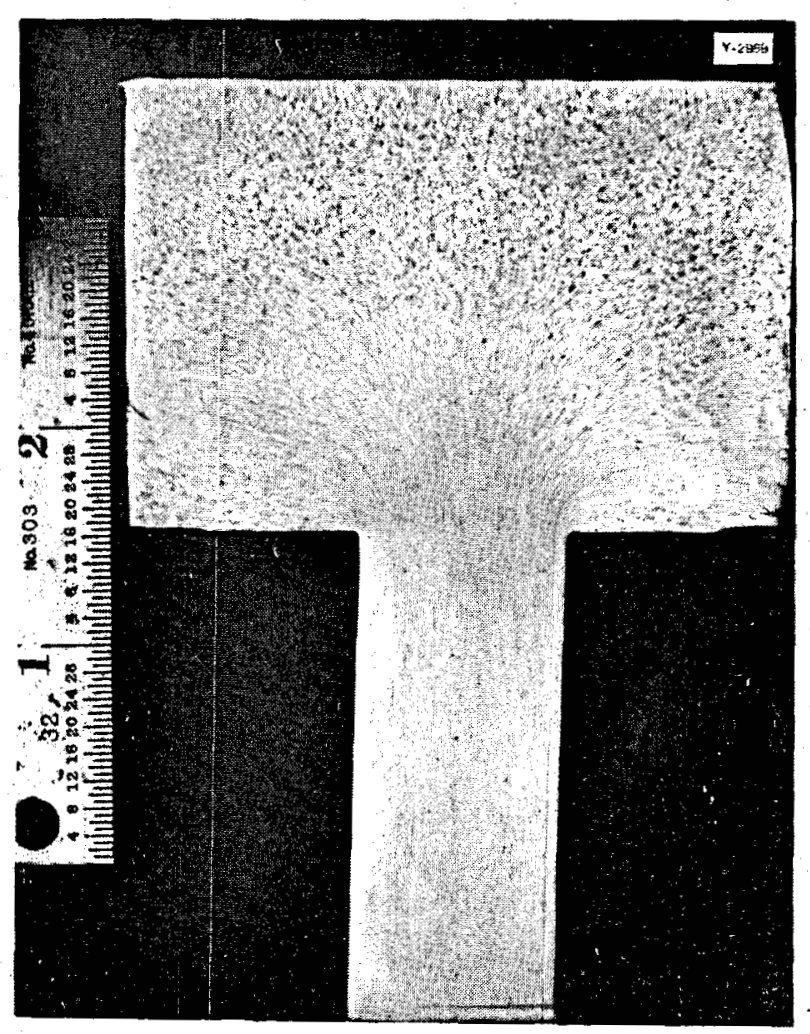

Fig. 38 - Partially Extruded Thorium Billet in Section.

need to be enclosed in a protective sheath. This becomes necessary when fission products must be contained or when the metal is subjected to a corrosive atmosphere. Since zirconium is one of the more promising materials for such use in a reactor; zirconium cladding of thorium was investigated. When rod or tubing of thorium is required, the most economical method of fabrication would be a duplex or triplex extrusion to form the clad rod or tubing in one operation.

Since zirconium was available only in small quantities, inside cladding of thorium tubing was attempted first. A billet of thorium was machined into a cylinder 3 in. OD by 1 in. ID and 6 in.

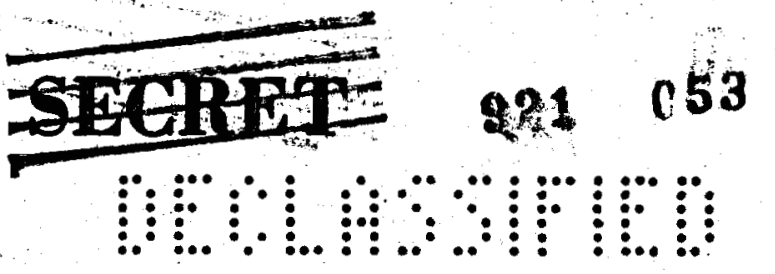




\section{INTER IM REPORT ON METALLURGY OF THORIUM AND THORIUM ALLOYS}

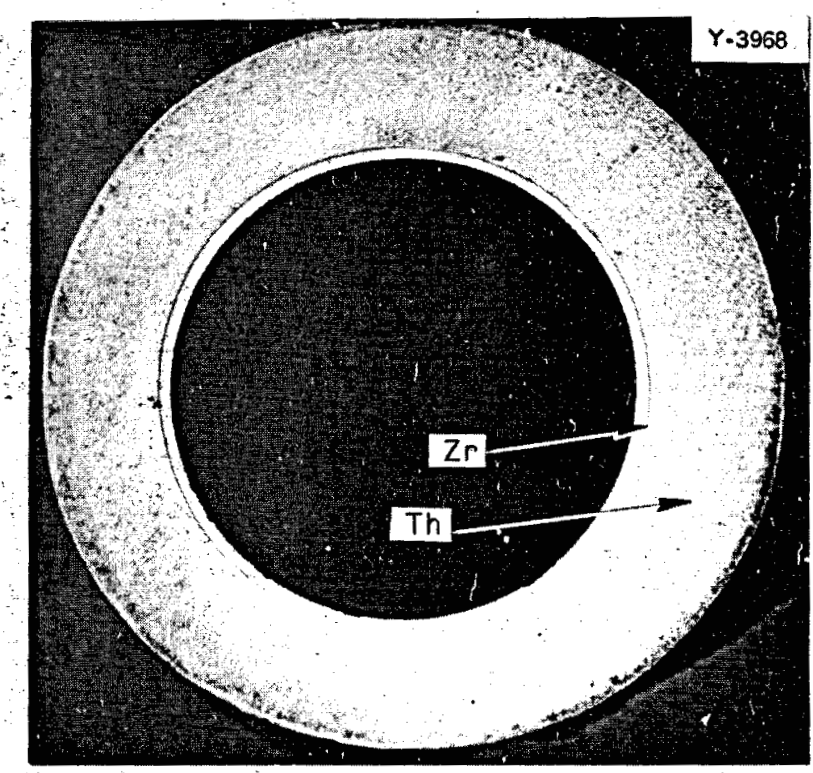

a.

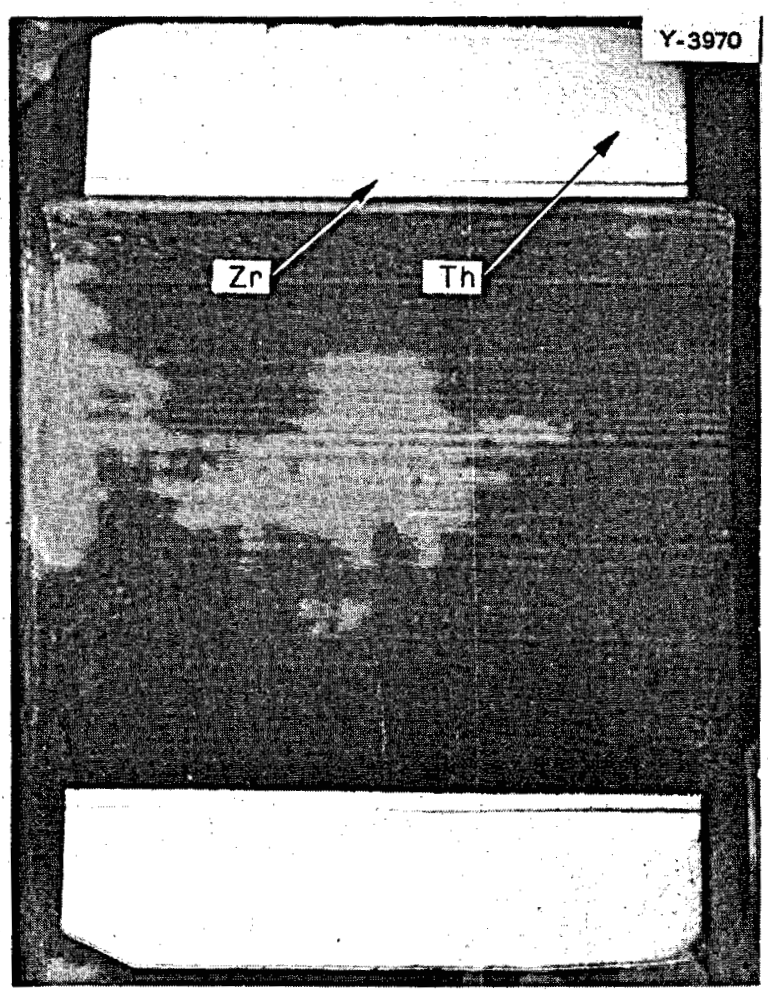

b - Longitudinal section of tubing showing zirconium liner in thorium tube

Fic. 39 - Sectional Views of Duplex Th-Zr Tube Produced by Extrusion.

long. A cylinder of zirconium $5 / 8$ in. ID by 1 in. OD and 6 in. long was prepared and forced inside the thorium billet. The thorium.was welded to the zirconium at each end of the billet to prevent interfacial contamination during the preheating operation.

An extrusion.was made at a temperature of $725^{\circ} \mathrm{C}$ with a reduction ratio of $16 / 1$ to produce a thorium tube $7 / 8$ in. $O D$ by $1 / 2$ in. ID with an inside cladding of about 0.020-in. thickness of zirconium. The zirconium cladding was fairly uniform, and the tubing had good surface both on the inside and outside. Sectional views of the tubing showing the thickness and uniformity of the zirconium liner are given in Fig. 39.

The trailing end of the extrusion showed a thinner and less uniform cladding of zirconium. Sectional views of the trailing end of the tube are shown in Fig. 40, while photomicrographs of the $T h-Z r$ interface

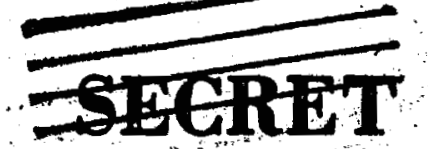




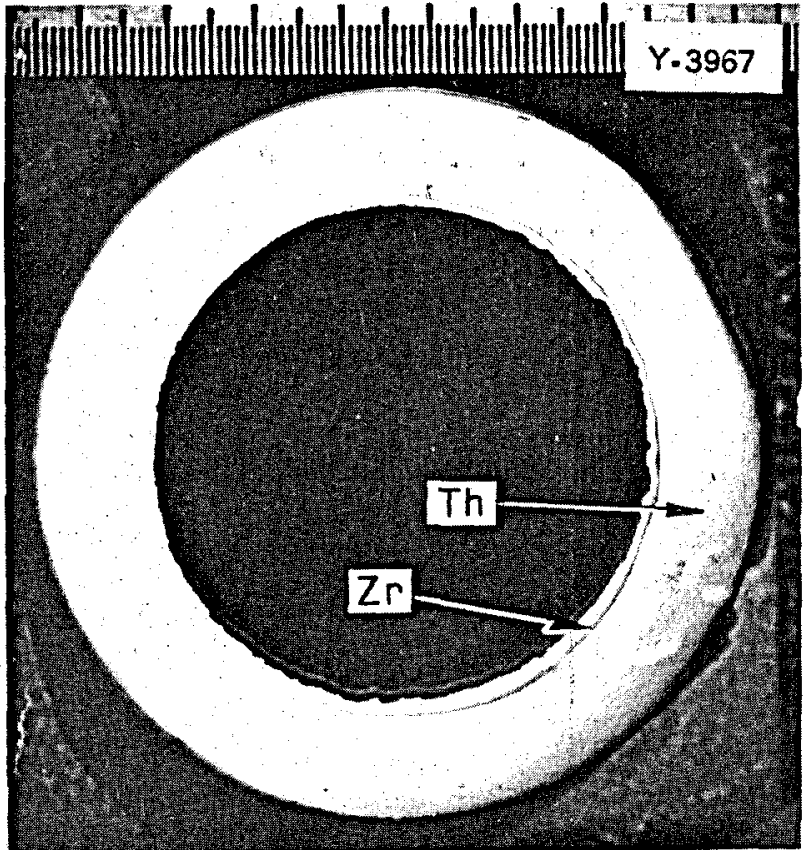

a - Crossisection of tubing showing irregular lining of zirconium in thorium tube

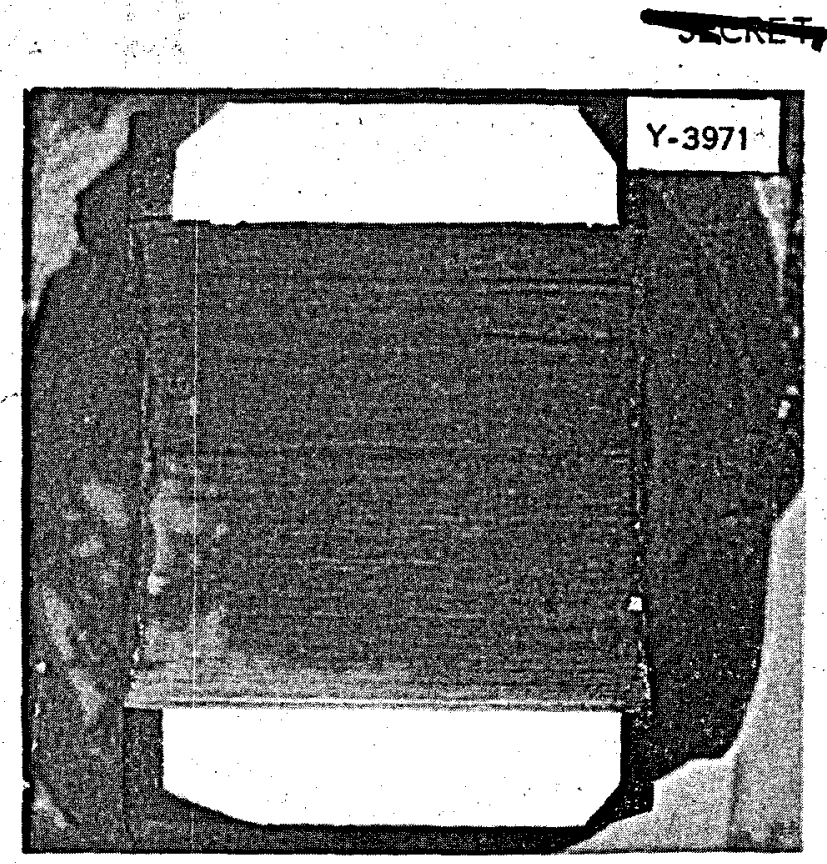

b - Longitudinal section of tubing showing zirconium lining in thorium tube

Fig. 40-Sectional Views of Trailing End of Extruded Thorium Tube with Zirconium Lining.

are shown in Fig. 41, where the nonuniformity of cladding may be noted again. However, the zirconium and thorium seemed to be bonded sat is factorily along the entire length of the tube. A piece of the tubing was sectioned longitudinally and then subjected to a bend test by bending back to flatten the specimen, thus putting the zirconium liner in tension. The back bend passed through approximately 200 degrees before the $z$ irconium liner failed in tension. The broken ends of the zirconium were gripped and pulled in an atempt to mechanically strip the zirconium from the thorium. However, the zirconium again failed without stripping. A photomicrograph of the Th-Zr interface at a high magnification (Fig. 42) shows that a metallurgical bond was obtained. The sharp line of demarcation was caused by preferential attack of the thorium during polishing and etching and is not a void. This preferential attack tends to obscure the diffusion layer between the two metals, but Fig. 42a shows the diffusion quite well. It seems that the conditions of temperature and reduction used in this extrusion are sufficient to insure bonding.

Machining - Thorium may be machined easily using conventional tools and methods. Its machining qualities are 


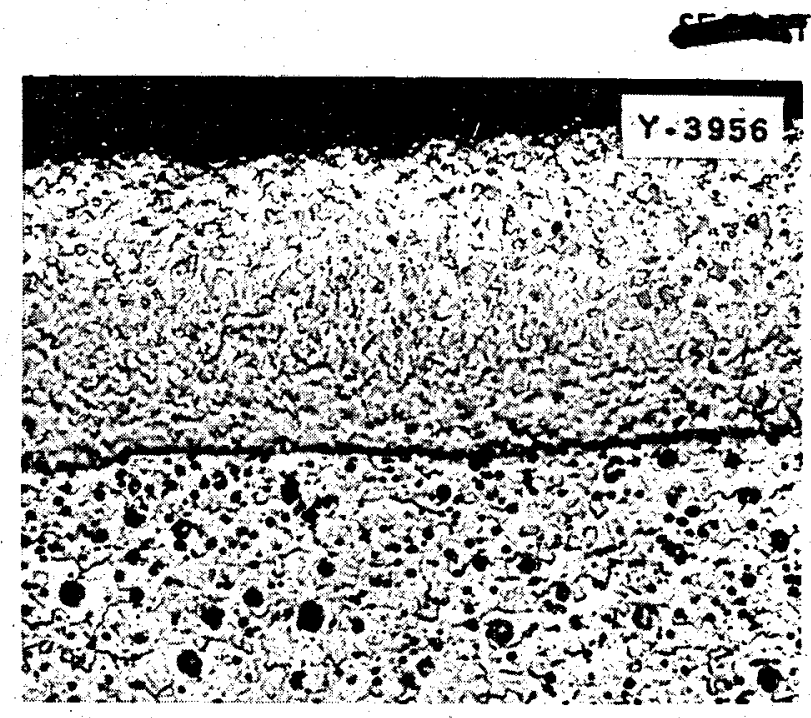

a Leading end of extrusion

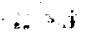

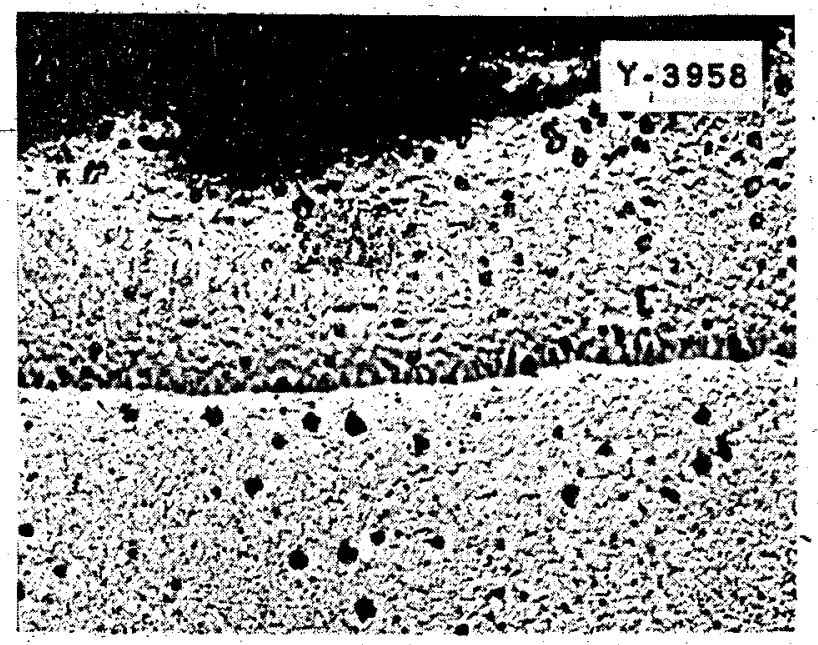

b - Trailing end of extrusion

Fig. 41 - Th-zr Interface of Extruded Th Tube clad on Inside with $\mathrm{zr}$.

comparable to those of mild steel. A coolant is customarily used, and it was found that a sulphonated cutting oil worked satisfactorily. Little. or no fire hazard has been found when machining clean metal using a coolant.

Reaming is the only machining operation requiring special care. The best tool is a spiral flute reamer which is kept very sharp and run at a slow speed. Only a small amount of material, approximately 0.003 in., may be removed without tearing and roughening the surface.

Other machining operations such as milling, turning, drilling, and sawing may be performed using standard tools and conventional practices.

Welding - Preliminary welding tests were made using Ames thorium sheet. Butt-welds, edge-welds, and lap-welds were readily made in a helium atmosphere, using Heliarc welding techniques.

Welding wasdone in a dry-box, using Grade A tank helium as an inert gas. Prior towelding, the box was partially evacuated and allowed to refill with helium a few times to purge air from the box. Helium was fed through the torch continuously. Welds obtained were clean and bright, and had an excellent appearance. Brief experiments using an argon stream through the torch, and using helium in the torch in an air atmosphere, did not produce good welds.

Satisfactory welds using helium have been produced using both $A C$ and DC straight-polarity arcs... All welds were made on thin sheets (up to 0.080 in thick) and no filler rod was used. Butt-welds were made without restraint; when pieceswere clamped while welding, cracks developed in the weld. A second pass over the welded joint also developed cracking.

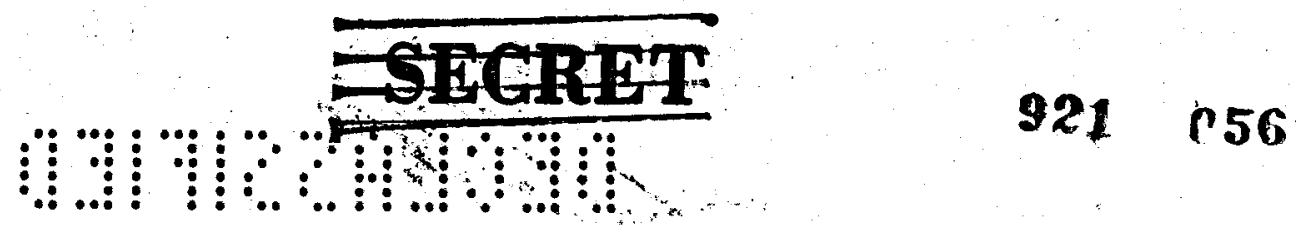




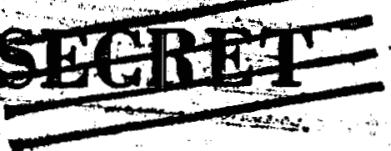

INTER IM REPORT ON METALLURGY OF THORIUM AND THORIUM ALLOYS

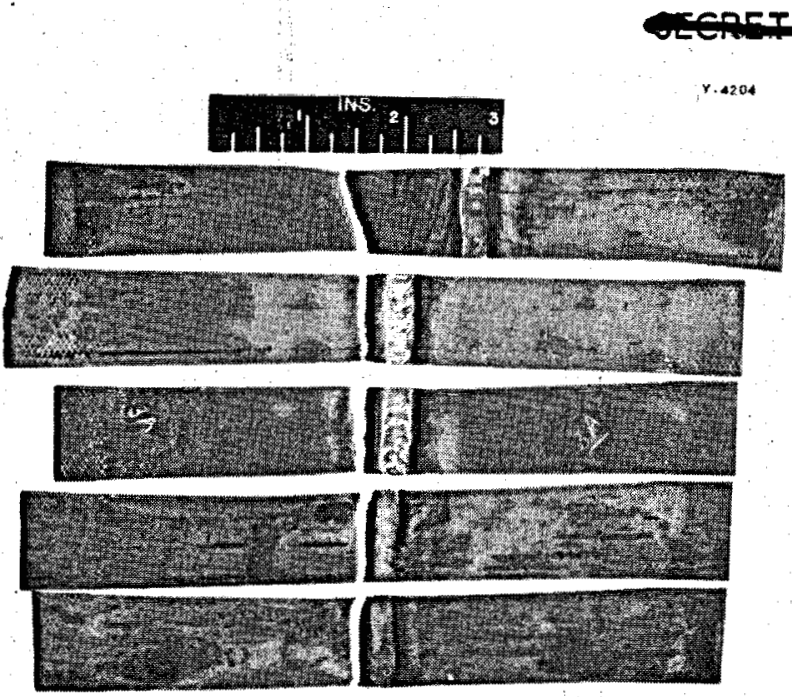

Fig. 43 - Broken Tensile Specimens of Welded Ames Thorium.

\section{ALLOY DEVELOPMENT}

A study of thorium-rich alloys was undertaken to develop possible structural materials to be used as reactor components. The alloys were prepared

by induction melting and evaluated by physical testing.

Melting Procedures - The first problem was that of developing melting techniques to prepare alloys with a minimum of contamination. A literature search revealed that the two most promising refractories for use as melting crucibles were beryllium oxide and zirconium oxide. Since beryllium oxide was expensive and toxic, it was decided to investigate the use of zirconia as a crucible material. Stabilized zirconia crucibles which were commercially available in a variety of sizes were obtained and subjected to severe service conditions while melting thorium. The induction furnace used for melting the thorium consisted of a 3 in.-diameter silica tube with a water-cooled vacuum head. The vacuum head contained a sight glass for observation of the melted metal. The high-frequency induction coil around the silica tube was connected to a 20-kw Ajax spark-gap converter for a
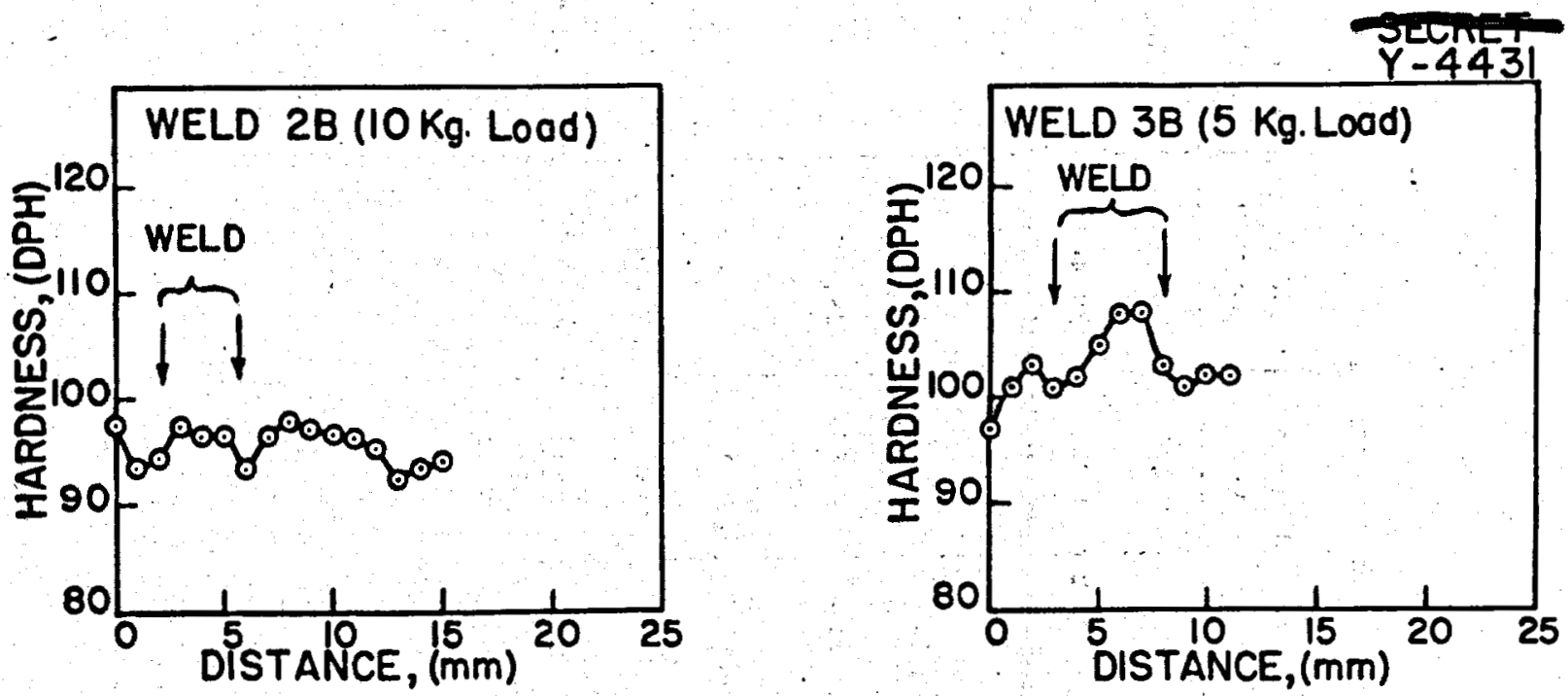

F1g. 44 - Hardness Traverses of Thor Ium Telds. 


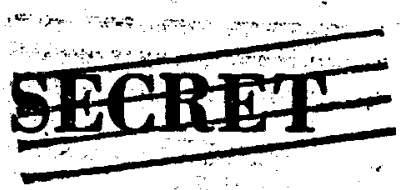

\section{INTER IM REPORT ON METALLURGY OF THORIUM AND THORIUM ALLOYS}

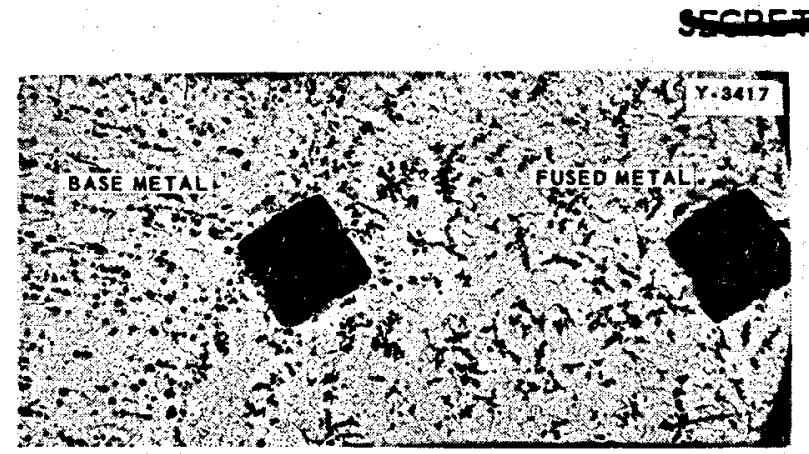

Microstructure of thorium weld showing junction between parent and fused metal

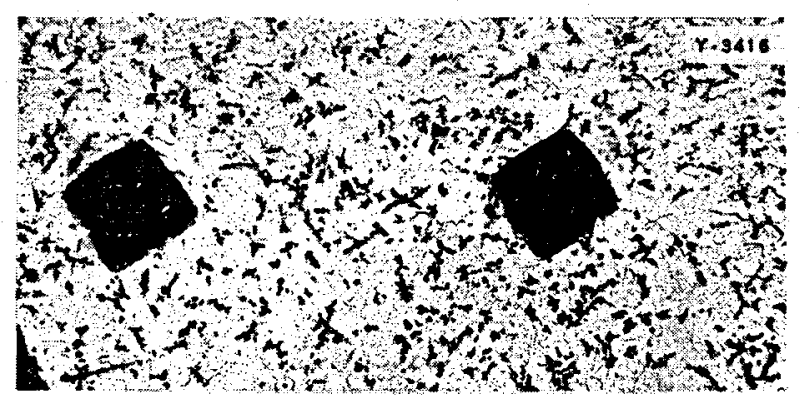

Microstructure of thorium weld near center of fused metal

F1g. 45 - Photonicrograph of Welded Ames Thorium Specimens.

power source. The zirconia crucible was filled with thorium metal and inserted into a graphite crucible which acted as a heater. This assembly was set in a larger crucible of zirconia or magnesia, and powdered beryllium oxide was packed in the annular space between the two crucibles for insulation. A schematic diagram of the furnace and crucibles is shown in Fig. 46. Thorium was melted and heated to $2100^{\circ} \mathrm{C}$ and allowed to cool. It was found that the zirconia melting crucible had been attacked by the thorium, and as much as one-half of the wall thickness had been eroded away. Another crucible was filled with thorium and heated to $1800^{\circ} \mathrm{C}$. Some preliminary attempts were made to obtain a cooling curve to determine the melting point of thorium so that the crucible was alternately heated and cooled. However, the crucible was held at elevated temperatures for approximately $5 \mathrm{hr}$ and was held at $1800^{\circ} \mathrm{C}$ or higher for at least $3 \mathrm{hr}$. There was no erosion of the zirconina crucible comparable to that found after a very short time at $2100^{\circ} \mathrm{C}$. The crucible appeared to be only slightly attacked, and was in good condition except for a change to a darker color. However, a layer of reacted material adhered to the melted ingot of thorium and flaked off after cooling. Spectrographic analysis showed this layer to be thorium with a moderate amount of zirconium, showing that some reduction of the zirconia had taken place. Repeated melting of thorium in zirconia at $1800-1850^{\circ} \mathrm{C}$ showed no great amount of at tack on the zirconia crucible, so it was concluded that zirconia could be used at this temperature, although it was recognized that some reduction probably occurred. Beryllia crucibles were used for melting in a similar manner and it was found that considerable cttack on the crucible walls occurred at $1950^{\circ} \mathrm{C}$ or above. It was felt that zirconia was equally as good as beryllia, if not superior.

While the refractories were being tested, it was found that the vacuum system was inadequate for maintaining a high vacuum at $1800^{\circ} \mathrm{C}$. Apparently the refractories degassed and allowed surface oxidation of the thorium. When this happened, a tenacious film of oxide obscured melting, since the original charge outline was preserved

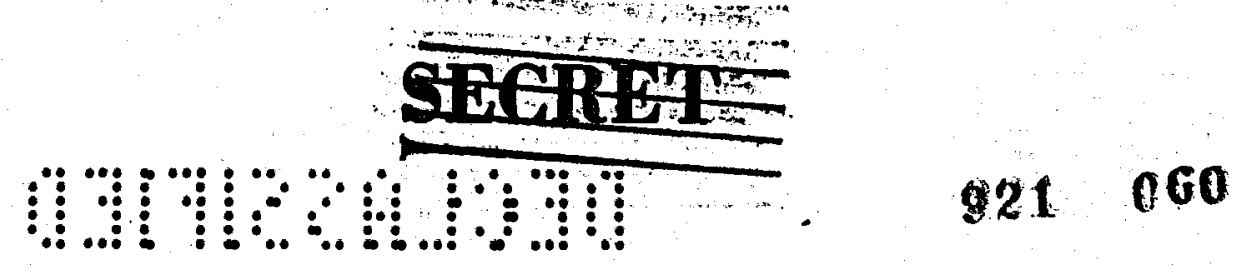




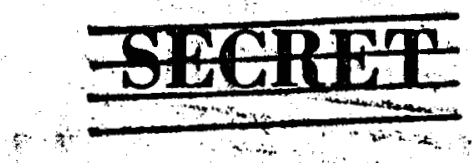

INTERIM REPORT ON METALLURGY OF THOR IUM AND THORIUM ALLOYS

UNCLASSIFIED

$Y-4357$

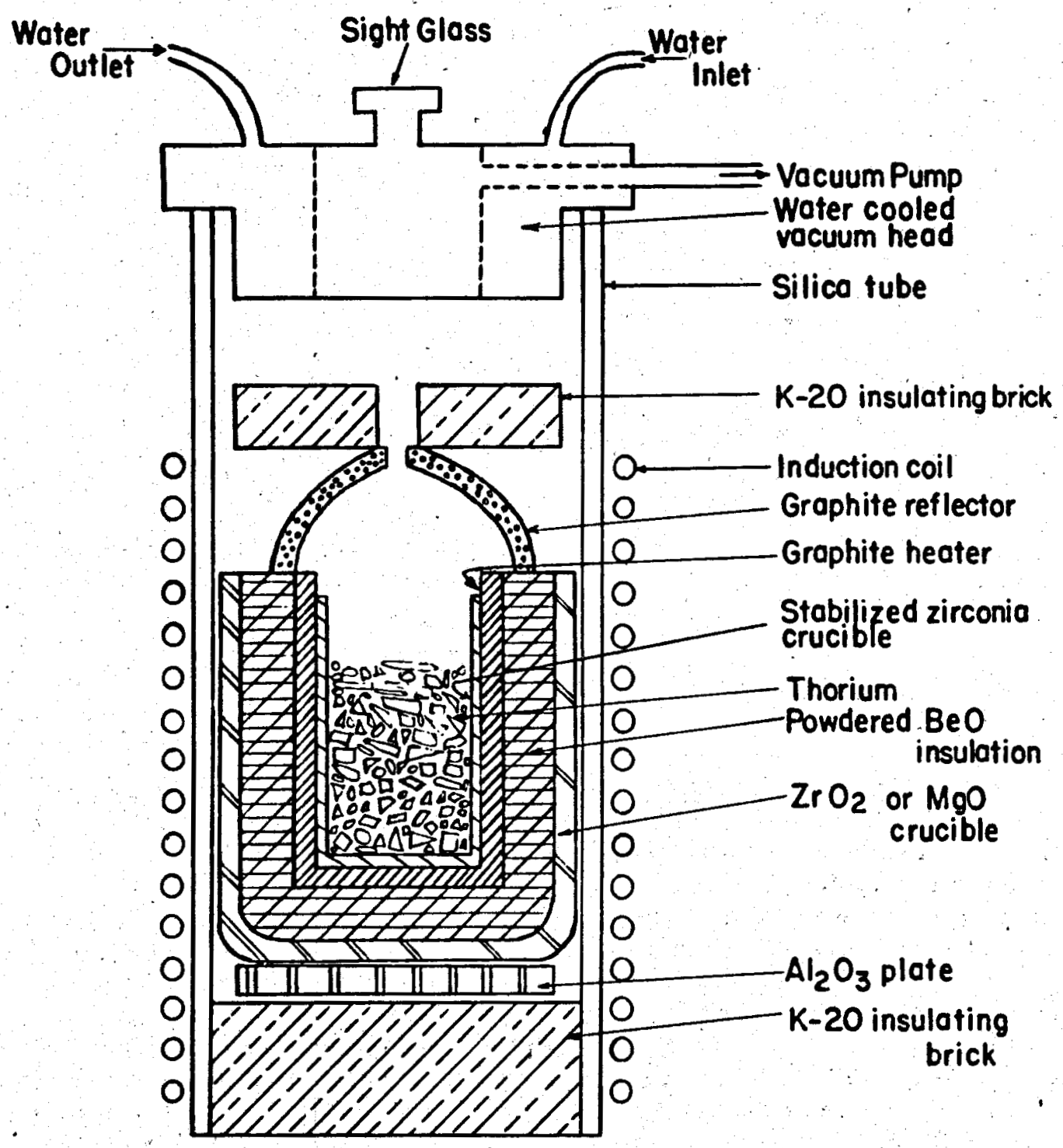

Fig. 46 - Schematic Diagram of Silica-Tube Vacuum Furnace for melting Thorium. 


\section{INTER IM REPORT ON METALLURGY OF THOR IUM AND THORIUM ALLOYS}

UNCLASSIFIED

with molten metal inside. A secondary effect was carburization of the thorium. This difficulty was avoided by removing the graphite heater, since it was found that thorium heated satisfactorily by self-induction. The problem of gas evolution and accummulation during melting was solved by substituting for the small vacuum pump a $500-c$ fm package pumping unit. Attempts to determine the melting point by observation of a thermal arrest in the cooling curve were unsuccessful because of the low latent hect of fusion of thorium. However, a definite change of slope in the cooling curve was observed at approximately $1625^{\circ} \mathrm{C}$. A sample which was heated only to $1700^{\circ} \mathrm{C}$ was melted. Thus, the $1625^{\circ} \mathrm{C}$ temperature was considered to be a reasonable value for the melting point.

The silica tube furnace was not suitable for alloying work, since it was difficult to adaptit for casting. Therefore, a tilting furnace was designed and constructed to permit melting and casting in vacuum. The furnace proper consisted of a water-cooled copper tank $16 \mathrm{in}$. in diameter and 18 in.high. The induction coil, insulation, melting crucible, and mold are housed inside the vacuum chamber. Interchangeable induction coils and molds permit melting and casting a variety of: ingot sizes and shapes. The furnace is attached to a $500-\mathrm{cfm}$ package pumping unit through a rotary " 0 " ring seal vacuum joint. The entire furnace is tilted to pour the molten metal from the crucible into a mold supported at right angles to the crucible. Since the coil was inside the racuum chamber, it was necessary to use relatively low-frequency current to prevent arcing between turns of the coil... The furnace was powered with $50-k w, 3000-c y c l e$ motor

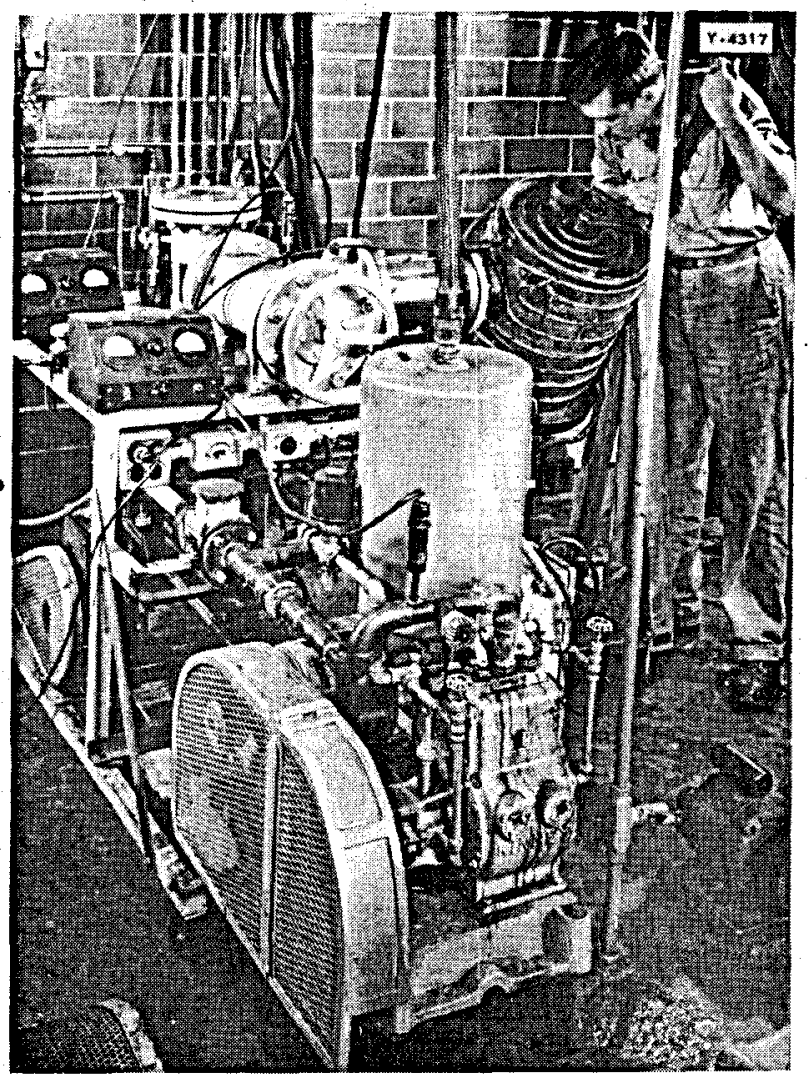

Fig. 47 - Tilting Vacuum Furnace

generator set. Apicture of the furnace with attached vacuum system is shown in Fig. 47.

Thorium was melted in zirconia crucibles in the tilting furnace and cast into zircon molds. Because a high vacuum was maintained at, all times (less than 1 micron pressure), the metal was cleaner than when melted in the silica tube furnace. The metal which was used for melting stock was Ames thorium which had been forged and rolled into rods $1 \frac{1}{2}$ in. in diameter. A photomicrograph of this material is shown in Fig. $48 \mathrm{a}$. Figures $48 \mathrm{~b}$ and $c$ show the typical cast structure obtained when melted and allowed to 


\section{INTER IM REPORT ON METALLURGY OF THORIUM AND THORIUM ALLOYS}

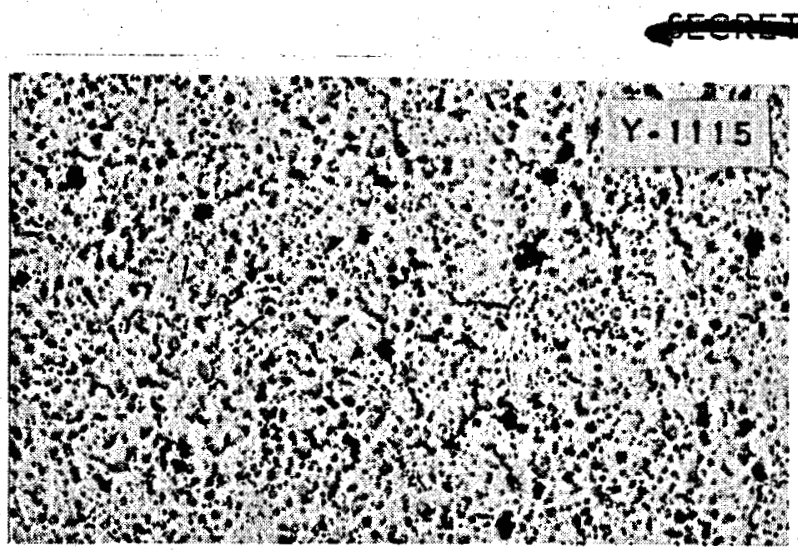

a - Ames thorium, forged and rolled rod as-received

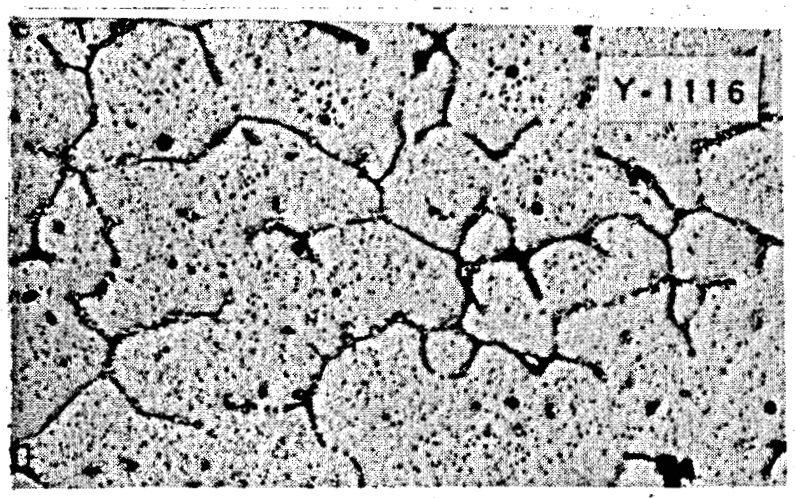

b - Ames thorium melted in $\mathrm{ZrO}_{2}$ crucible, solidified in crucible

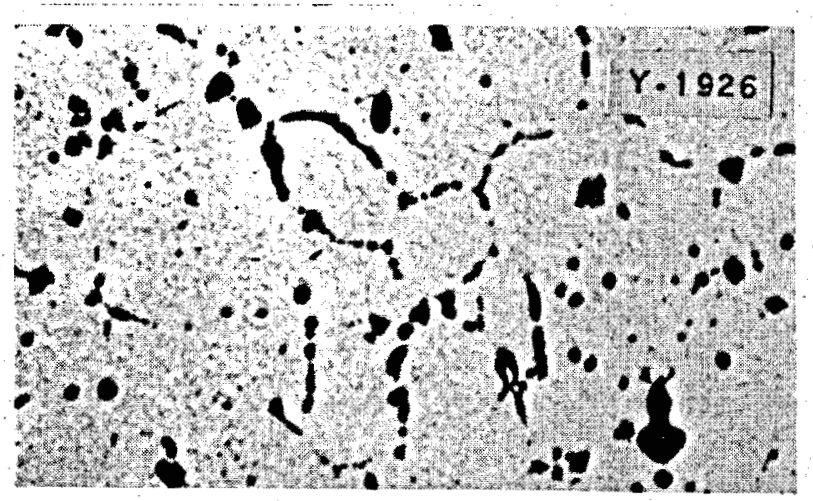

c - Ames thorium melted in $\mathrm{ZrO}_{2}$ crucible and cast in vacuum

Fig. 48 - Photomicrographs of Ames Thorium Before and After Melting in $\mathrm{ZrO}_{2}$. solidify in the $\mathrm{ZrO}_{2}$ crucible and when vacuum cast.

Testing Procedures - Binary alloys were prepared by melting and casting small ingots in the vacuum furnace. A. flat face along the entire length of the ingot was polished and examined metallographically. A hardness transverse was made along the length of the ingot and this, along with the microscopic examination, established the homogeneity of the alloy. A part of the thorium ingot was then coldrolled easily. If the cold-rolling were successful, sheet metal tensile specimen and corrosion-test specimens could be prepared by cutting the finished sheet into'pieces of the desired size and shape. If the cold-rolling were not successful, there remained the possibility that a preliminary hot-working to break up the cast structure of the alloys might improve the cold-workability of the material. Hot-working was performed by forging and extrusion, since these operations were performed more conveniently at high temperature than rolling. Since it was found that some alloys were not arenable to cold-working, even after a preliminary hot breakdown, the final size was obtained by hotworking.

A series of alloys were prepared by additions of the following elements: aluminum, beryllium, cerium, niobium, chromium, indium, manganese, titanium, selenium, and $z$ irconium. The hardnesses of these cast alloys are tabulated in Table 11. It may be seen that titanium forms alloys with thorium which are much softer than Ames thorium. Zirconium alloys show the same tendency to a lesser degree. This softening is presumably due to removal of carbon and/or oxygen from solid solution with 


\section{INTER IM REPORT ON METALLURGY OF THORIUM AND THORIUM ALLOYS}

TABLE 11

Hardness of Cast Thorium Alloys (A11 hardness Values Rockwell "B" Scale)

\begin{tabular}{l|r|r|r|r}
\hline $\begin{array}{l}\text { Alloying } \\
\text { Element }\end{array}$ & \multicolumn{4}{|c}{ Alloy Content } \\
\hline & $2 \%$ & $4 \%$ & $6 \%$ & $8 \%$ \\
& & \multicolumn{4}{|c}{} \\
$\mathrm{Be}$ & 77 & 80 & - & 92 \\
$\mathrm{Si}$ & 92 & 98 & 102 & 80 \\
$\mathrm{Ce}$ & 60 & 57 & 52 & 60 \\
$\mathrm{Ti}$ & 2 & 8 & 4 & 37 \\
$\mathrm{Zr}$ & 24 & 22 & 41 & 36 \\
$\mathrm{In}$ & 80 & 85 & 86 & 80 \\
$\mathrm{Nb}$ & 54 & 46 & 24 & - \\
$\mathrm{Mn}$ & 65 & 60 & 71 & 70 \\
$\mathrm{Al}$ & 94 & 96 & 100 & - \\
$\mathrm{Cr}$ & 58 & 75 & 73 & - \\
\hline
\end{tabular}

the formation of stable carbides and oxides.

The alloys will be discussed briefly in the chronological order. in which they were investigated.

\section{Alloy Systems}

Th- $B e^{-}$- Since beryllium is a metal with good nuclear properties, the first alloys prepared contained from 1 to $10 \%$ Be by weight. It was found that addition of a small amount of Be markedly lowered the melting point of thorium and gave very fluid melt. The lower melting point and greater fluidity were desirable in that melting and casting operations were facilitated. Metallographic examination of the alloys showed that a brittle intermetallic compound was formed which made fabrication very difficult. Preliminary cold-rolling experiments showed that a very small reduction resulted in excessive cracking. The $1 \%$ Be alloy cracked after only $10 \%$ reduction by cold-rolling, and was cracked beyond use at $28 \%$ reduction in thickness. The workability of the $4 \%$ alloy was poorer, since it cracked seriously after $14 \%$ reduction. The $8 \%$ alloy cracked beyond use at only 5\% reduction: The thorium-beryllium system has been reported as having a thorium-rich eutectic at $7.75 \% \mathrm{Be}$ and $1215^{\circ}$. C. (1) This was substantiated in the present work, since the melting point of the $2 \%$ alloy was approximately $1200^{\circ} \mathrm{C}$. Photomicrographs of Th-Be alloys are shown in Fig. 49. Hardness indentations made with a diamond pyramid are shown in Fig. $49 \mathrm{~g}$. It may be seen that the matrix is much softer than the compound giving a DPH number of 170, while the primary crystals of compound range from 980 to 1206 DPH. Small billets of $4 \% \mathrm{Be}$.$96 \% \mathrm{Th}$ alloy were $\mathrm{jacketed}$ in copper cans and extruded at $1000^{\circ} \mathrm{C}$ into 3/8-in-diameter rods. It was thought that this preworked material might be more amenable to cold-rolling than the as-cast alloy. However, the alloy was still brittle and had a very low impact strength, since a piece of the rod could be broken easily by striking a sharp blow with a hamer. It was concluded that any working performed on Th-Be alloys must be done at elevated temperatures.

Th-Al - Aluminum has a relatively low absorption cross-section, good corrosion resistance, and is commonly used to jacket slugs of uranium for use as fuel in a reactor. Very little is known of the Th-Al system, especially on the thorium-rich side of the diagram. Thorium-aluminum alloys were made by addition to thorium of $2 \%$ to $8 \%$ by weight of aluminum. The approximate melting ranges of the alloys and 


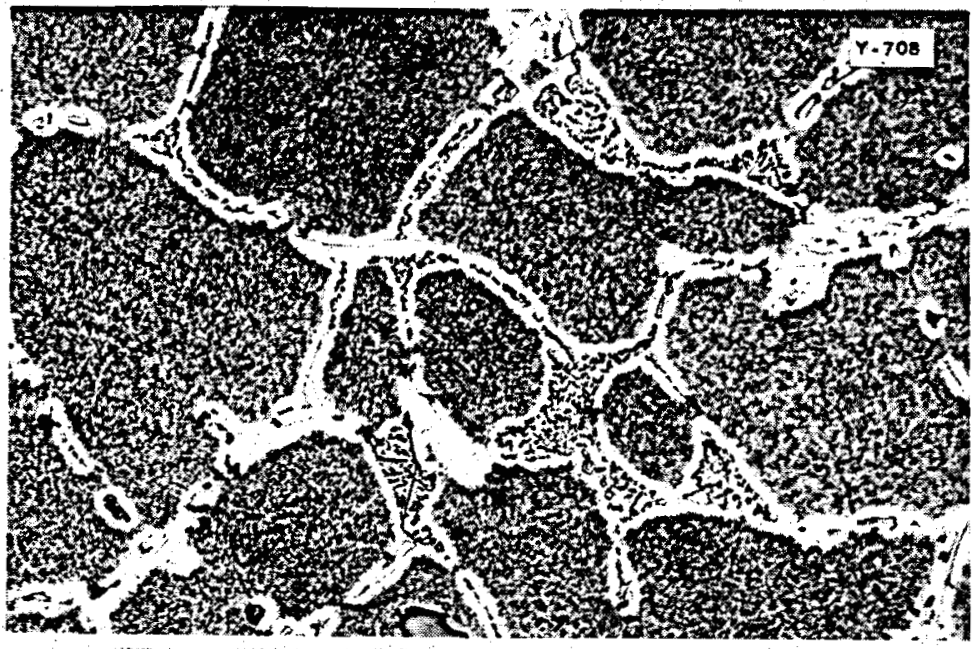

a $-0.25 \%$ Be (Original magnification $500 \mathrm{X}$; reduced to $295 \mathrm{X}$ in reproduction)

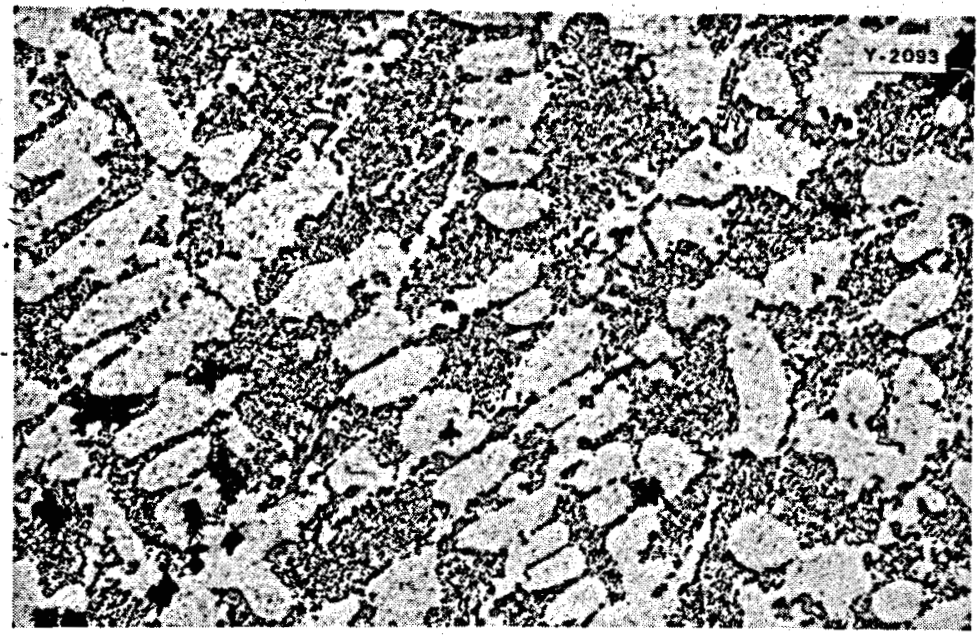

c - $1.5 \%$ Be (Original magnification $260 X_{\text {; }}$ reduced to $212 X$ in reproduction)

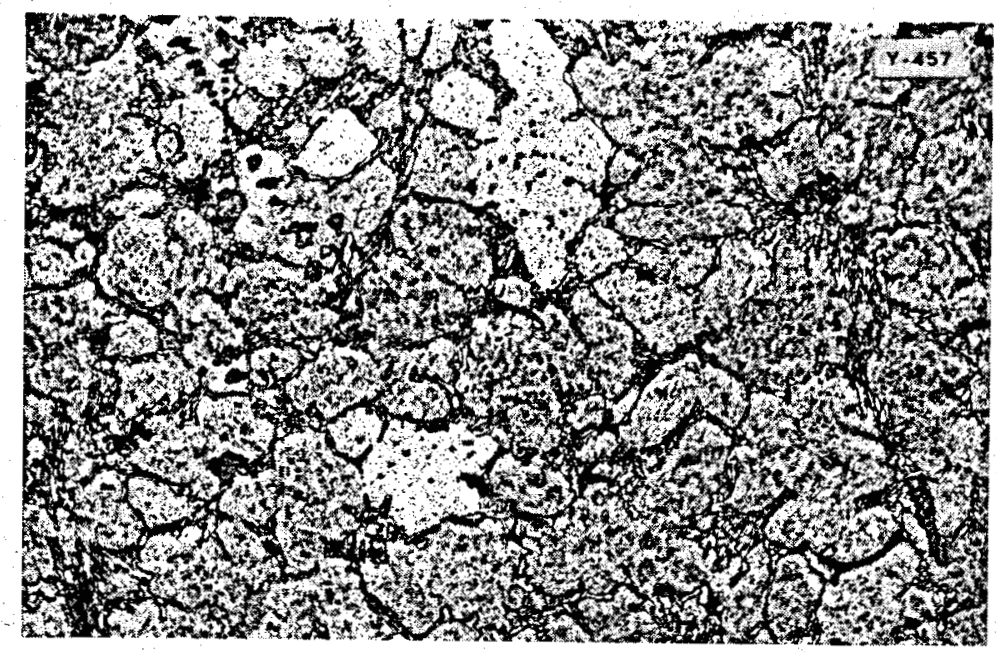

b - $1 \%$ Be (Original magnification $100 \mathrm{X}$; reduced to $59 \mathrm{X}$ in reproduction)

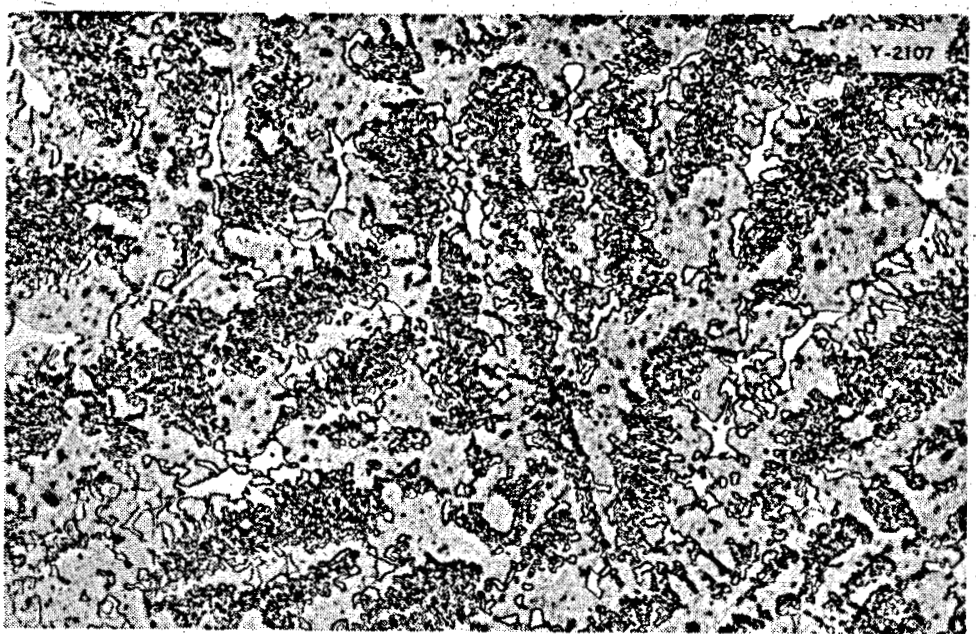

d - 2\% Be (Original magnification $250 \mathrm{X}$; reduced to $147.5 \mathrm{X}$ in reproduction)

$$
\begin{aligned}
& \text { Hardness: Primary Constituent DPH 980-1206 } \\
& \text { Matrix - DPH 164-179 }
\end{aligned}
$$

Fig. 49 - Photomicrographs of Th-Be Alloys. 


\section{INTER IM REPORT ON METALLURGY OF THOR IUM AND THORIUM ALLOYS}

\section{TABLE 12}

Thorium-Aluminum Alloys

\begin{tabular}{c|c|c}
\hline \hline $\begin{array}{c}\text { Composition } \\
\text { Wt\% Aluminum }\end{array}$ & $\begin{array}{c}\text { Approximate } \\
\text { Melting Range } \\
{ }^{\circ} \mathrm{C}\end{array}$ & $\begin{array}{c}\text { Hardnes s } \\
\text { Rockwell B } \\
\text { Scale }\end{array}$ \\
\hline 2 & $1285-1300^{\circ}$ & 94 \\
4 & $<1420$ & 96 \\
6 & $1300^{\circ}-1350$ & 100 \\
8 & $1235-1245$ & - \\
\hline
\end{tabular}

the hardness as measured on the ascast ingots are shown in Table 12 .

The precision of measurement of the melting temperatures was insufficient to warrant any conclusion as to the recorded maximum in the plot of melting points vs composition between $2 \%$ Al and $8 \% \mathrm{Al}$. It was taken as an indication only that the liquidus temperature is not changing rapidly over this composition range. The hardness of all the alloys was much higher than that of pure thorium.

The aluminu alloys were very brittle, and when cold-rolling was attempted the alloys containing more than $2 \%$ Al crumbled immediately. The $2 \%$ alloy cracked after $1 \%$ reduction and broke up completely during the second pass through the rolls. Metallographic examination showed that a second phase (compound) was present even with $2 \%$ Al content. Hardness indentations are shown for the $2 \%$ aloy in Fig. 50a. The matrix was somewhat softer than the compound, al though much harder than pure thorium. The matrix hardness was Vickers 150 , while the compound showed a Vickers hardress of 200 to 400 . At $4 \%$ Al content, the alloy wa found to consist of almost pure compound (Fig. 50b).

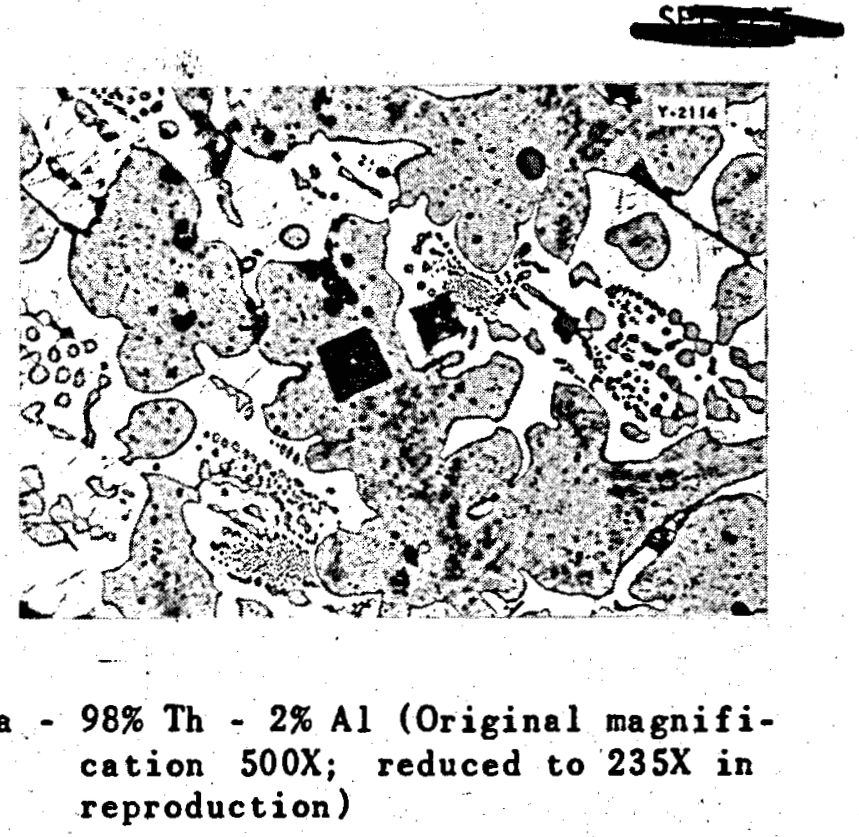

Hardness: Matrix - DPH 148-158

Constituent - DPH 200-400 Aggregate - $R_{b} 95$

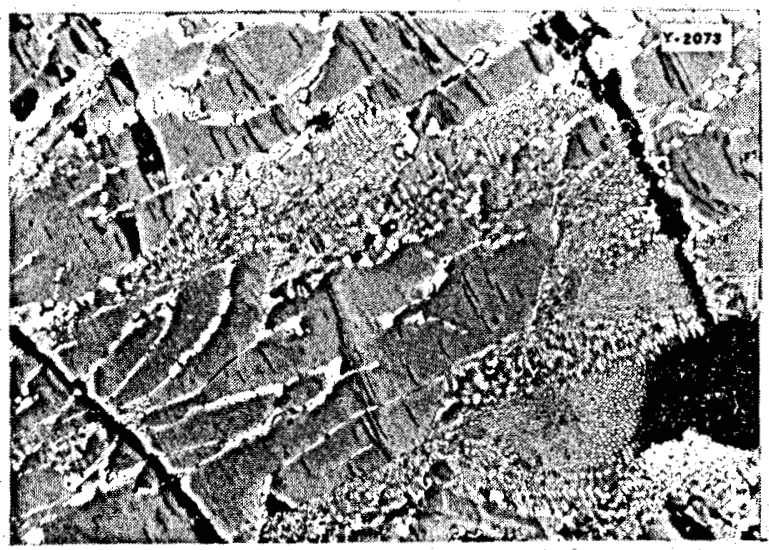

b - $96 \%$ Th - 4\% Al (Original magni fication $200 \mathrm{X}$; reduced to $94 \mathrm{X}$ in reproduction)

Hardness: DPH 400

F1g. 50-Photomicrographs of Th-Al Alloys.

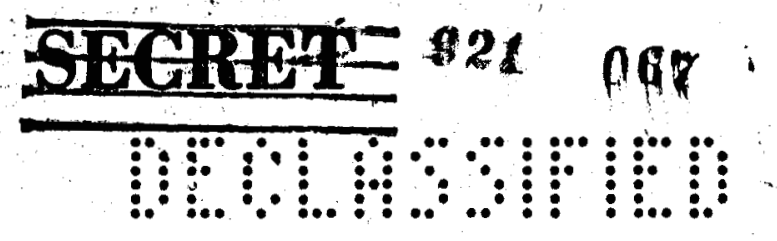




\section{INTER IM REPORT ON METALLURGY OF THORIUM AND THORIUM ALLOYS}

Since a compound $\mathrm{Th}_{3} \mathrm{Al}$ would contain 3. $73 \% \mathrm{Al}$, this is probably the composition of the compound. The hardness of this compound was measured as Vickers 410. The first alloy containing $4 \%$ aluminum was polished, examined for homogeneity, and filed away immediately after melting and reserved for later testing. Two weeks later it was found the alloy had spontaneously disintegrated into a fine powder (approximately 100 mesh). A second alloy of the same composition was prepared, and polished with carbon tetrachloride as a coolant. Another sample of the ingot was sealed in an evacuated glass tube to eliminate atmospheric corrosion. Since neither of these .samples disintegrated, it was concluded that atmospheric corrosion was probably the cause of the powdering.

In an attempt to follow the progress of the corrosion, a $4 \% \mathrm{Al}-96 \% \mathrm{Th}$ alloy was cast, immediately cut into a metallographic specimen without using water, and placed on the stage of a research metallograph. The specimen was observed for six days and no change was detected in the microstructure. At the end of six days, one half of the surface of the specimen was covered with a protective coating of plastic (tygon) and the entire specimen wet with water. Four hours after the exposure, the uncoated side of the specimen had rather large pits in the elongated grains. The coated side had decomposed to a lesser extent, showing that the tygon protective coating was inadequate. After $72 \mathrm{hr}$, the elongated grains in the uncoated portion of the specimen had been almost completely decomposed. However, the corrosion was confined to the long slender grains, and the more equi-axed grains and the eutectic were not attacked. The progress of corrosion is shown in Fig. 51. An X-ray spectrometer trace of the decomposed alloy showed a very complex pattern which could not be identified completely. Thorium and thorium dioxide lines were present with number of additional lines.

Th-Si - It has been reported that silicon additions to thorium improves the corrosion resistance. (1), (5) A series of alloys were prepared, containing from $2 \%$ to $8 \%$ silicon. The approximate melting ranges and aggregate hardness of each alloy are given in Table 13. All of the alloys contained a brittle second phase as shown in Fig. 52. It has been reported that the system Th-Si contains a eutectic at $10 \mathrm{At}$. \% Si with melting point of $>1300^{\circ} \mathrm{C}$ and a hypereutectic phase (intermetallic compound). The present work is in agreement with this, since all of the alloys prepared were hypereutectic. The largest amount of the hard constituent was found in the alloy containing $6 \%$ silicon. The constituent was extremely hard and brittle, in fact, so brittle that it was difficult to obtain satisfactory diamond pyramid impressions. The impressions are shown in Fig. 52 b. The light area had a Vickers hardness number of 200 to 270 , while the harder dark constituent was measured as 858 Vickers. The aggregate hardness on the Rockwell B scale was 100 .

The brittleness of these alloys was apparent when fabrication was attempted. The material cracked badly with veryslight reductions when rolled. Cold rolling of the $2 \%$ and $4 \% \mathrm{Si}$ alloys resulted in reductions of only $10 \%$ and $2 \%$ respectively. One billet was hot-forged at approximately $900^{\circ} \mathrm{C}$ and cracked badly even at this elevated temperature. The Th-Si alloys

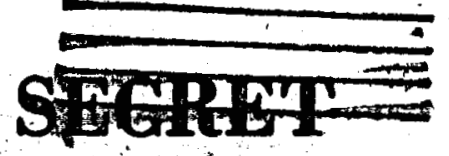


8

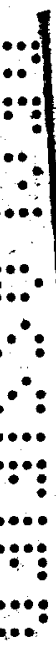

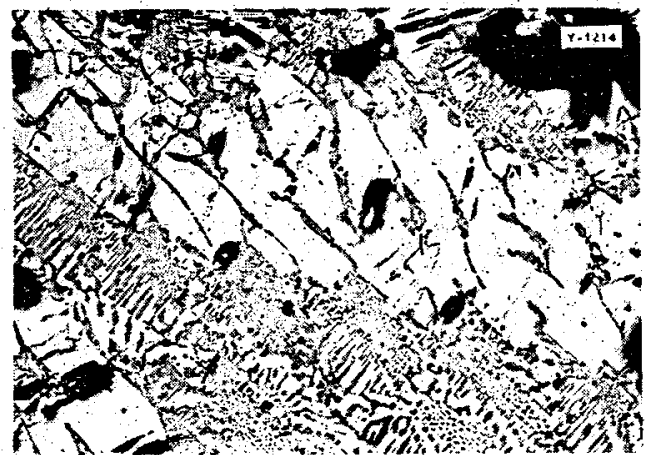

a - Tygon-coated surface $4 \mathrm{hr}$ a fter exposure to water i.

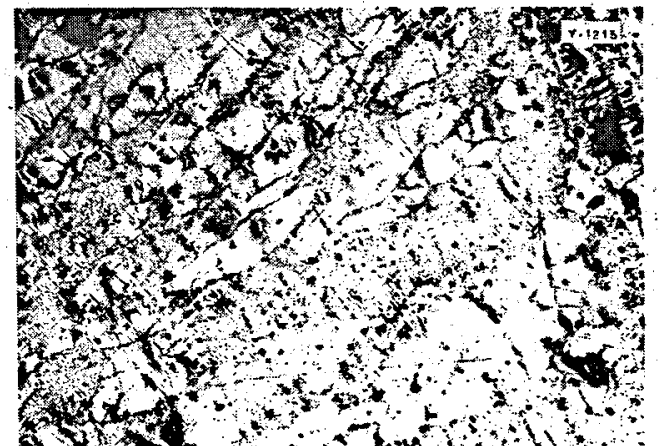
d - Uncoated surface $4 \mathrm{hr}$ after exposure to water

61

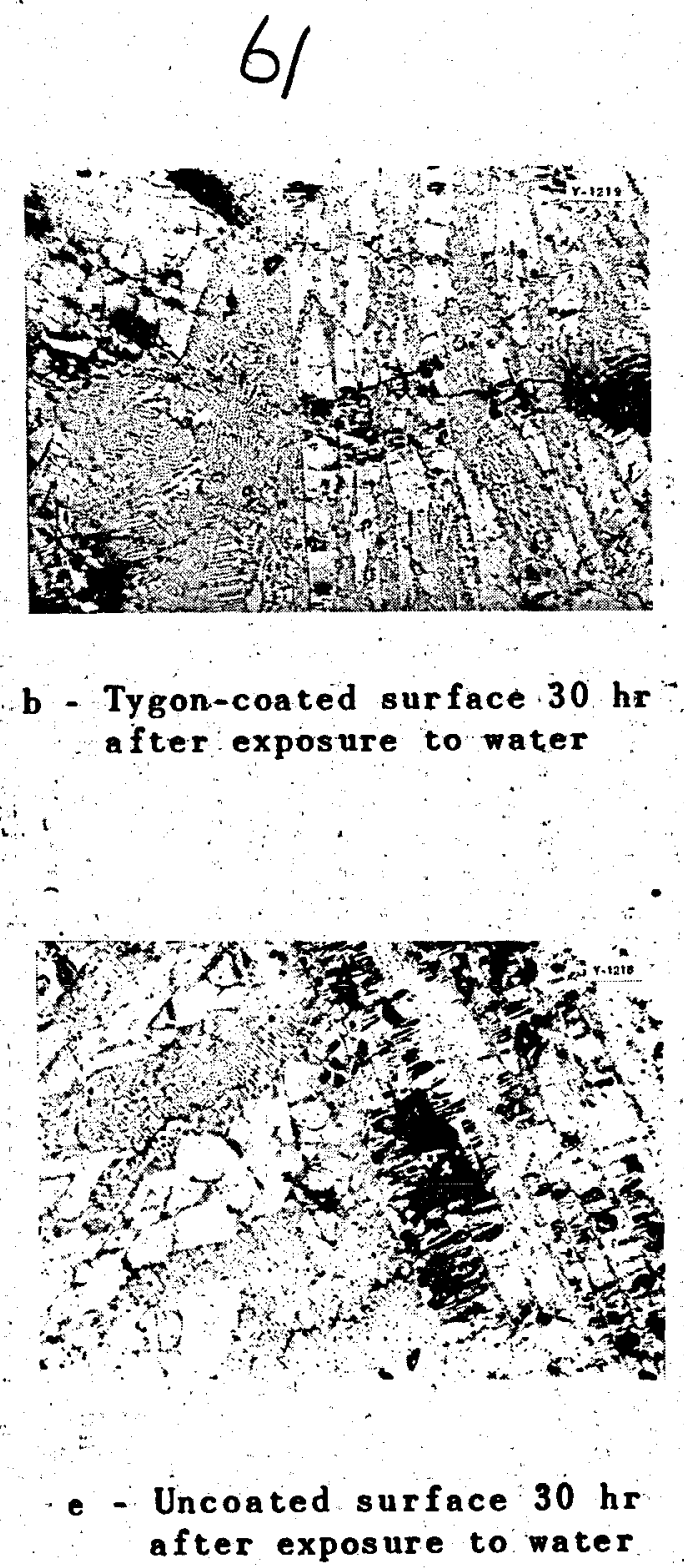

b - Tygon-coated surface $30 \mathrm{hr}$ after exposure to water

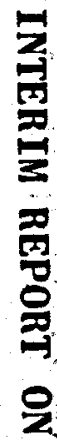

Tygon-coated surface $72 \mathrm{hr}$ after exposure to water.

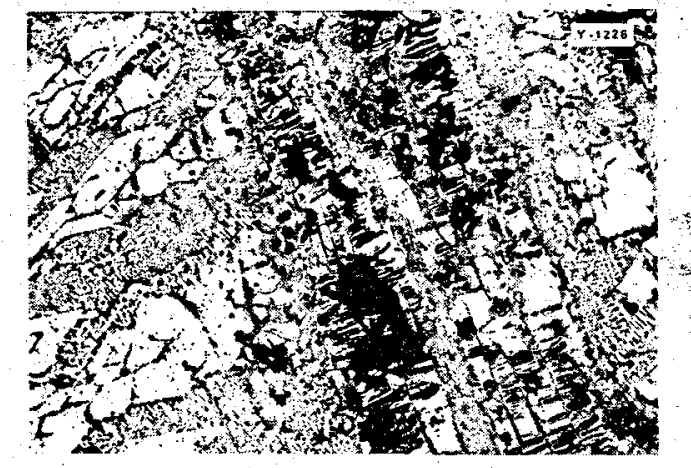

f - Uncoated surface 72 hr after exposure to water 


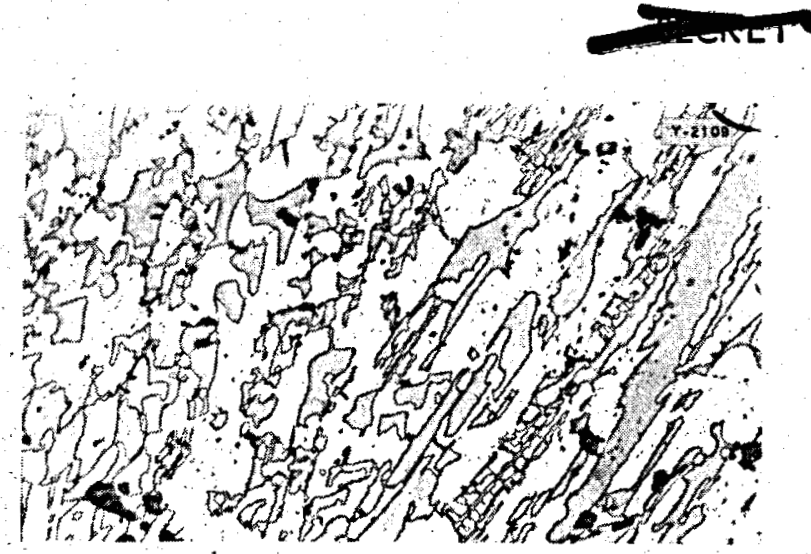

a - 98\% Th - 2\% Si (Original megnificetion $280 X_{\text {; }}$ reduced to $134.4 X$ in reproduction) Hardness: $R_{B} 91$

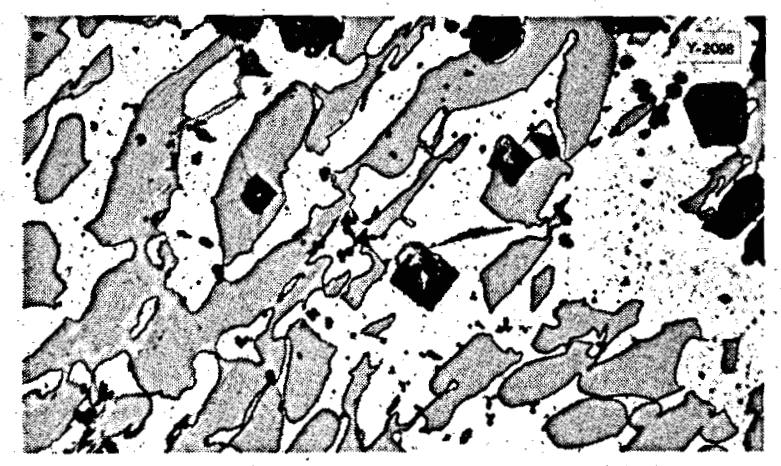

b - 96\% Th - 4\% Si (Original magnification $500 X_{\text {; }}$ reduced to $240 \mathrm{X}$ in reproduction) Hardness: Matrix DPH 200-270 Constit-
uent DPH 858

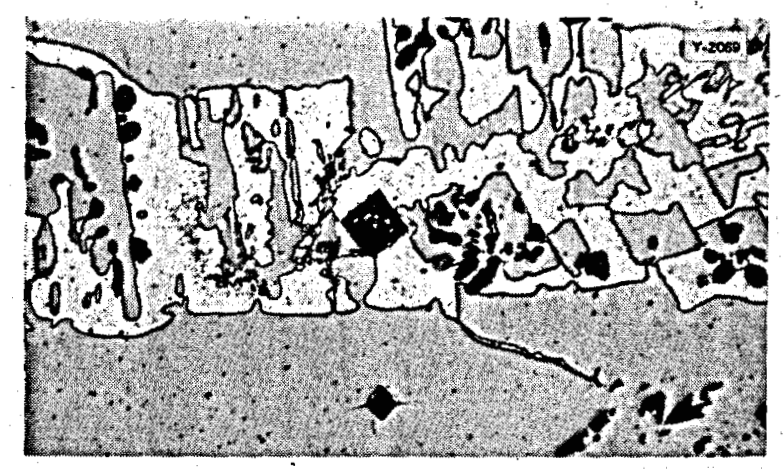

c - $94 \% \mathrm{Th}-6 \% \mathrm{Si}$ (Original magnification $500 X$; reduced to $248 \mathrm{X}$ in reproduction)

Fig. 52 - Photomicrographs of Th-Si Al10ys. showed a tendency to crumble and disintegrate in somewhat the same way as the aluminum alloys.

Th-Zr - Zirconium forms alloys with thorium which are softer than the Ames metal used for the alloy base. The hardness of the alloys varied from $\mathrm{R}_{\mathrm{B}} 22$ at $4 \% \mathrm{Zr}$ to $\mathrm{R}_{\mathrm{B}} 36$ at $8 \%$ zirconium content. Preliminary rolling experiments showed that all of the cast zirconium alloys $(2-8 \% \mathrm{Zr})$ could be cold-rolled to $95 \%$ reduction in thickness without serious cracking. Ingots, after melting and casting, were coldrolled into plate. Corrosion-test spęcimens and tensile-test specimens were machined from the plate end tested. The zirconium alloys had poor resistance to corrosion in $100^{\circ} \mathrm{C}$ distilled water and were, in general, inferior to pure Ames thorium in this respect.

The tensile specimens, 0.060 in. thick and 0.505 in. wide at the reduced section, were tested at a constant strain rate of 0.1 in. per minute.

The results of the tensile tests of $2 \%$ zirconium alloys are shown in Table 14. Control samples of the thorium from which the alloys, were prepared were tested also.

The tensile strength of the $2 \% \mathrm{Zr}$ alloys was somewhat lower than the original thorium. An indication of a yield point was observed in the loadelongation curve of the annealed alloys as shown in the typical curve of Fig. 53. The $2 \% \mathrm{Zr}$ alloys which was tested in the cold-worked state did not show a yield point and showed a higher strength than either the annealed or cold-worked Ames thorium. However, the ductility of the $\mathrm{Zr}$ alloys appeared to be lower than in the case of the pure Ames thorium. 


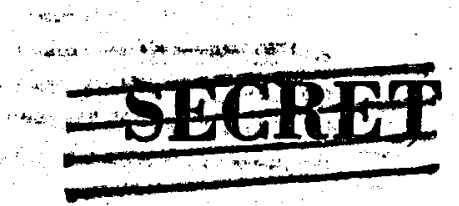

\section{INTER IM REPORT ON METALLURGY OF THORIUM AND THORIUM ALLOYS}

TABLE 13

Thorium Silicon Alloys

\begin{tabular}{c|c|c}
\hline Composition, & $\begin{array}{c}\text { Approximate } \\
\text { Melting Range }\end{array}$ & $\begin{array}{c}\text { Hardness } \\
\mathrm{R}_{\mathrm{B}}\end{array}$ \\
\hline $2 \% \mathrm{Si}$ & $1380-1420$ & 92 \\
$4 \% \mathrm{Si}$ & $1420-1480$ & - \\
$6 \% \mathrm{Si}$ & $>1500$ & 105 \\
\hline
\end{tabular}

Examination of the microstructure of these alloys show that one might expect better workability than was found in the previous alloys. Figure 54 shows that zirconium alloys have only a small amount of second phase present at $8 \%$ zirconium content. Apparently, there is considerable solid solubility of zirconium in thorium. This corroborates the findings of Ames Laboratory in their investigation of the Th-Zr equilibrium diagram. It was reported that $z$ irconium was soluble in $T h$ up to $6.5 \%$.

Th-Ti - The only available information on the $T h-T i$ system stated that a eutectic at 2 wt per cent $T i$ and $1175^{\circ} \mathrm{C}$ was found. (1) This could not be verified in the present series of alloys. Although no precise measurement of the melting point of the $2 \%$ alloy was made, it appeared to melt at a temperature in excess of $1400^{\circ} \mathrm{C}$. The photomicrograph of the $2 \% \mathrm{Ti}$ alloy is shown in Fig. 55a, and does not appear to be near a eutectic composition. The matrix does not have the characteristic appearance of a eutectic and, in the case of the $4 \% \mathrm{Ti}$ alloy shown in Fig. $55 \mathrm{~b}$, the second phase outlining the grain boundaries of the primary constituent does have a typical eutectic structure. The $6 \%$ and $8 \%$ alloys are shown in Figs. $55 \mathrm{c}$ and $d$, respectively, and show very little change in microstructure.. As noted previously, the hardness of the titanium alloys was much lower than Ames thorium. The Rockwell hardness (B scale) of the Ames thorium used to prepare the Ti alloys was approximately $R_{B} 60$. The hardness of the alloys ranged from $R_{B} 2$ for the $2 \%$ alloys to $R_{B} 37$ for the $8 \%$ alloy. The $T i$ alloys could be fabricated easily. by cold-rolling and weré comparable

TABLE 14

Thor ium-Zirconium Tensile-Test Data

\begin{tabular}{|c|c|c|c|c|c|}
\hline Specimen No. & Zr Content & $\begin{array}{l}\text { Hardness } \\
\text { (Vickers) }\end{array}$ & $\begin{array}{c}\text { Per cent } \\
\text { Elongation in } \\
\text { 2-in. gage length }\end{array}$ & $\begin{array}{l}\text { Per cent } \\
\text { Reduttion } \\
\text { in Area }\end{array}$ & $\begin{array}{c}\text { Tensile } \\
\text { Strength }\end{array}$ \\
\hline A429A (annealed) & $2 \%$ & 62.4 & 25 & 26.0 & $29,180 \mathrm{ps} \mathrm{i}$ \\
\hline A429B (annealed) & $2 \%$ & 62.4 & 25 & 26.6 & $29,735 \mathrm{psi}$ \\
\hline $\begin{array}{c}\text { A429C (cold-rolled } \\
85 \%)\end{array}$ & $2 \%$ & 104.0 & - & - & $49.660 \mathrm{psi}$ \\
\hline $\begin{array}{r}\text { Thorium (Ames } \\
\text { annealed) }\end{array}$ & 0 & 85.1 & 50 & 64.0 & $32,895 \mathrm{ps} \mathrm{i}$ \\
\hline $\begin{array}{c}\text { Thorium (cold-rolled } \\
85 \%)\end{array}$ & 0 & 102.3 & 37.5 & 57.0 & $40,775 \mathrm{psi}$ \\
\hline
\end{tabular}

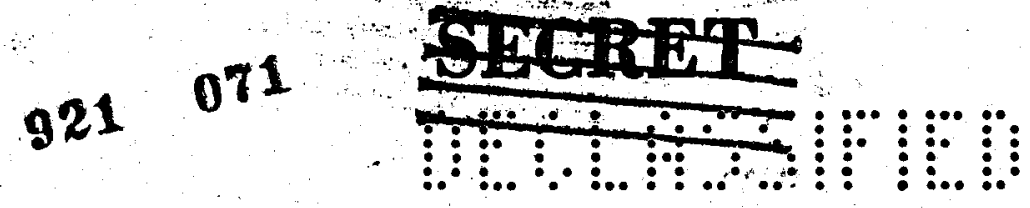




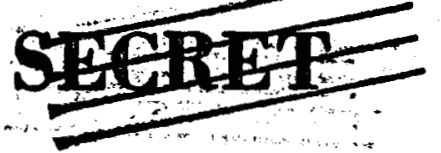

INTERIM REPORT ON METALLURGY OF THORIUM AND THORIUM ALLOYS

DWG. 12802

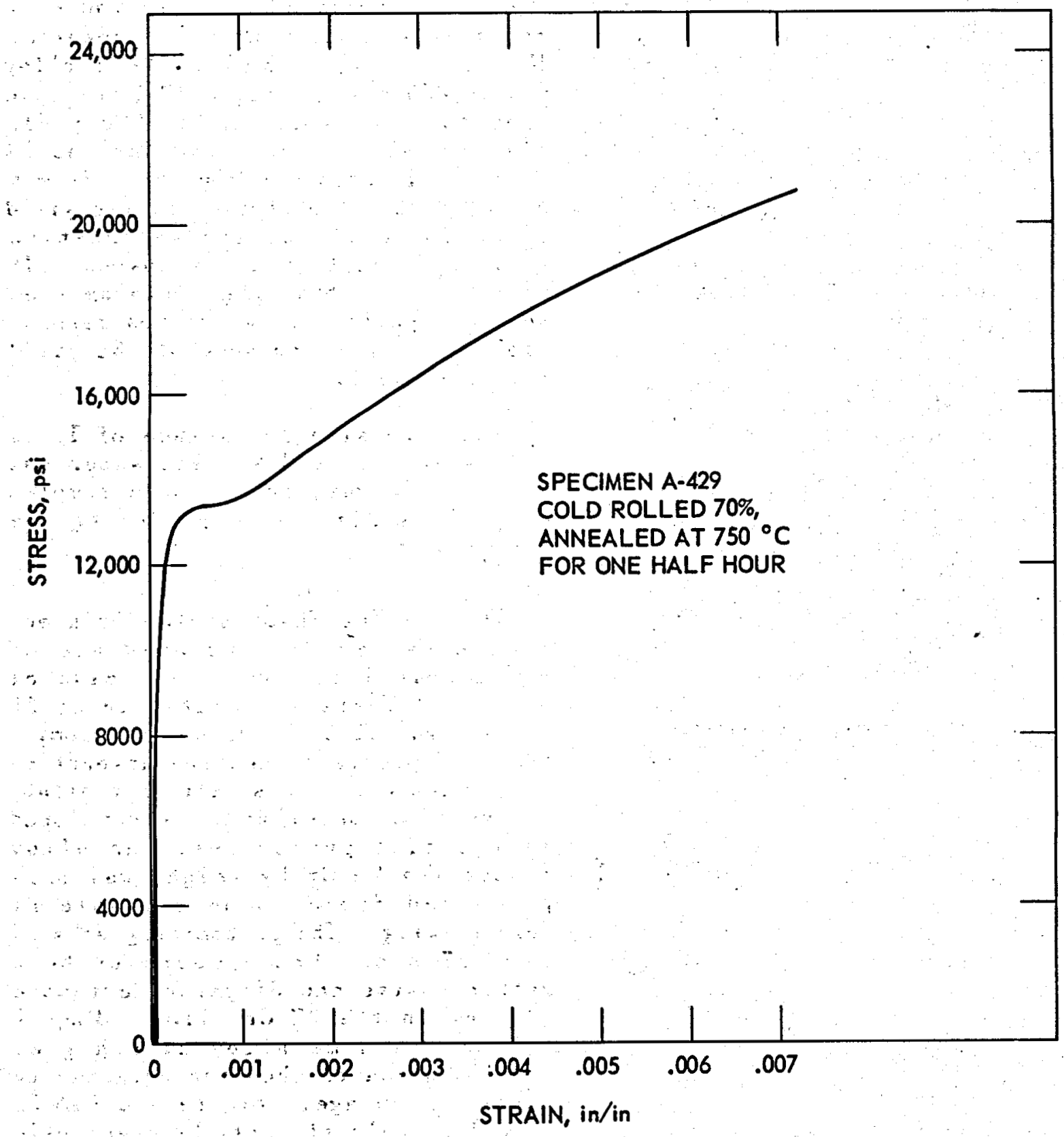

Fig. 53 - Load-Elongation Curve for $2 \% \mathrm{Zr}-\mathrm{Th}$ Alloy. 


\section{INTERIM REPORT ON METALLURGY OF THOR IUM AND THORIUM ALLOYS}

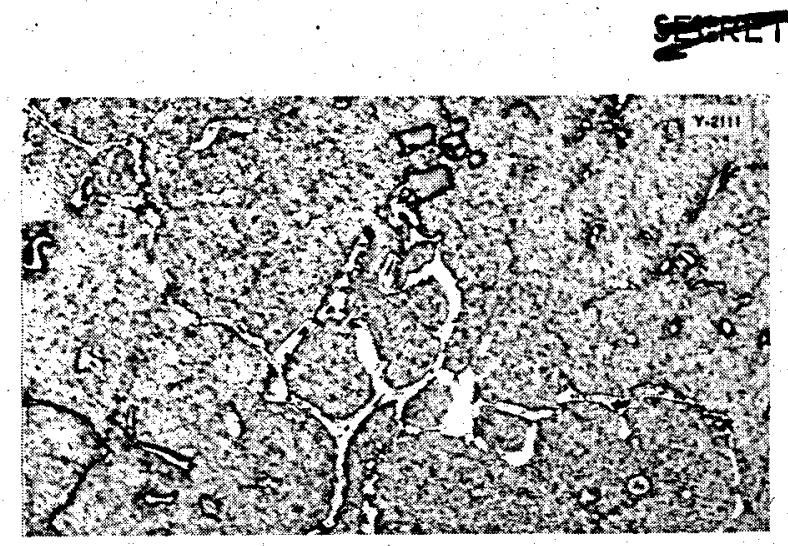

- 98\% Th - 2\% $\mathrm{Zr}$ (Original magnification $500 X$; reduced to $255 \mathrm{X}$ in reproduction)

Hardness: $R_{B} 24$ DPH 95

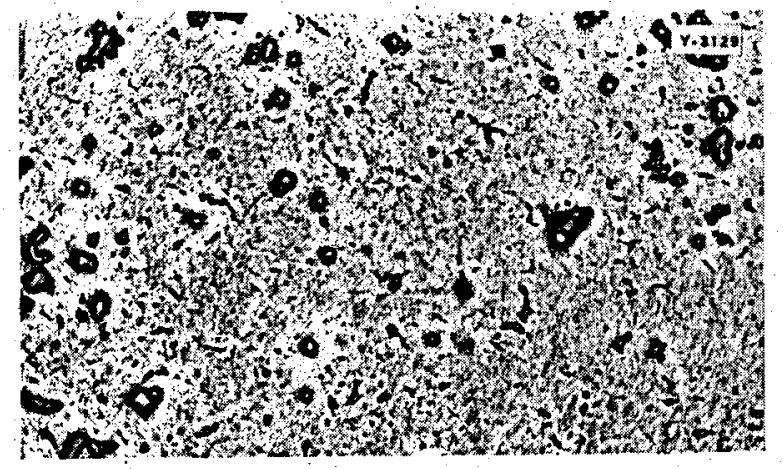

b - 94\% Th - 6\% Zr (Original magnification $250 \mathrm{X}_{\text {; }}$ reduced to $127.5 \mathrm{X}$ in reproduction)

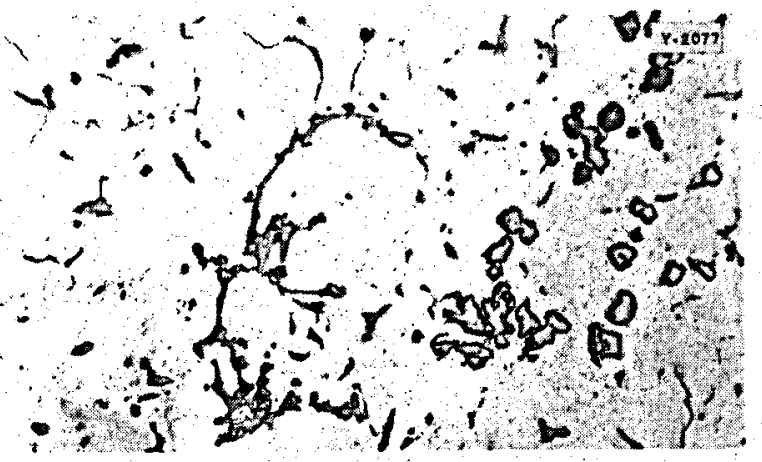

c $92 \% \mathrm{Th}-8 \% \mathrm{Zr}$ (Original magnification $500 x$; reduced to $255 x$ in reproduction)

Hardnes: DPH 95

F1g. 54 - Photomicrographs of Th-Zr Alloys. to Ames thorium in this respect. Cast ingots were cold-rolled $(75 \%$ reduction) into plate from which sheetmetal-type tensile specimens and corrosion-test specimens were prepared. The tensile strength of the $2 \% \mathrm{Ti}$ alloy was 24,050 psi, or slightly lower than that for Ames thorium $(32,000 \mathrm{psi})$. The load-elongation curve for the $2 \%$ Ti alloy is shown in Fig. 56. It may be noted that the characteristic yield point found in the load-elongation curve of Ames thorium is absent. It is postulated that the titanium ties up the impurity or impurities responsible for the appearance of the yield point of thorium.

The corrosion resistance of $\mathrm{Th}-\mathrm{Ti}$ alloys in $100^{\circ} \mathrm{C}$ distilled water was found to be very poor. Some samples completely disintegrated during the corrosion test.

Th-Cr - The Th-Cr system is a eutectic system with no evidence of solid solubility on either side of diagram. There is a eutectic at 25 At. $\% \mathrm{Cr}$ and $1235^{\circ} \mathrm{C}$. Although chromium has an appreciable neutron absorption cross-section, it was felt that dilute alloys of chromium might be developed with useful properties. An alloy containing $2 \% \mathrm{Cr}$ by weight was prepared and found to be workable by cold-rolling. The photomicrographs of Fig. 57 show what appears to be a rather coarse and dispersed eutectic present in the $2 \% \mathrm{Cr}$ alloy. Figure $57 b$ is the same alloy at a higher magnification to show the eutectic to better advantage. Figure $57 \mathrm{c}(4 \% \mathrm{Cr}$ by wt) is only slightly hypo-eutectic and shows a larger amount of eutectic. Sheet metal type tensile test specimens were prepared and tested. The cast ingots werecold-rolled into plate (approx. $75 \%$ reduction), and tensile

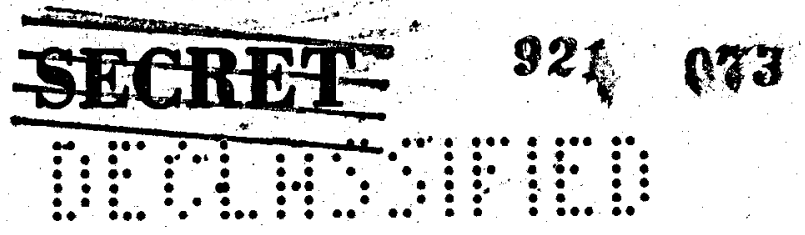




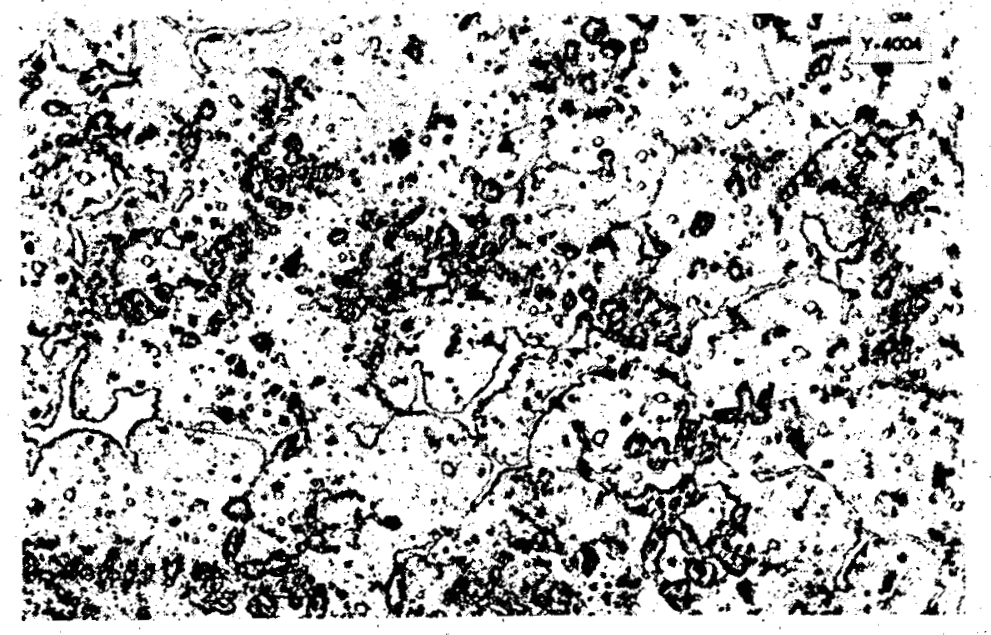

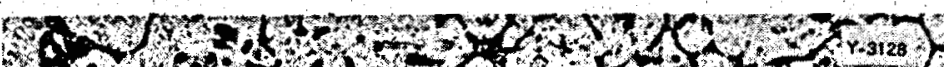

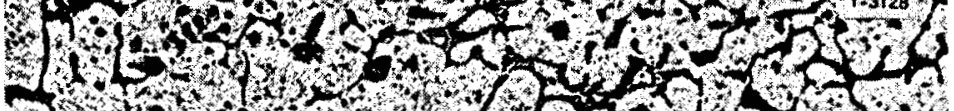

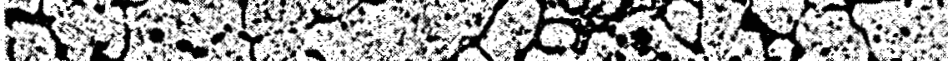

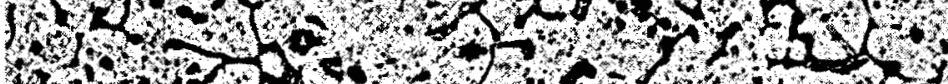

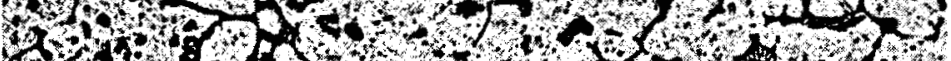

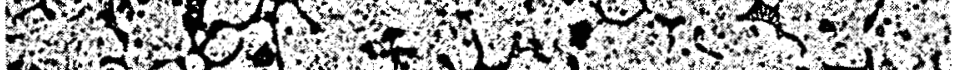

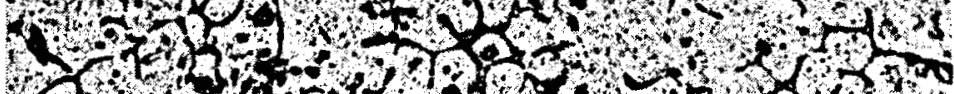

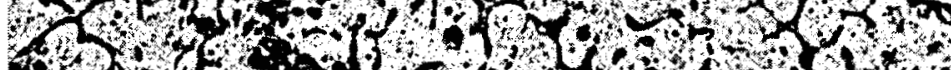

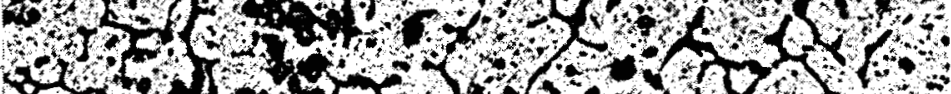

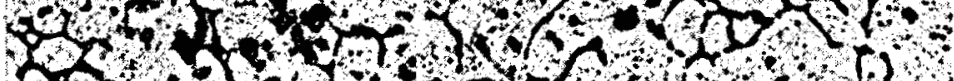

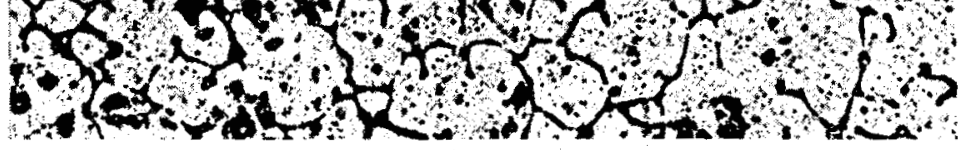

$\because \because$

b - $96 \% \mathrm{Th}-4 \% \mathrm{Ti}$ (Original magnification $250 \mathrm{X}_{\text {; }}$ reduced to $155 \mathrm{X}$ in reproduction) $250 \mathrm{X}$; reduced to $155 \mathrm{X}$ in reproduction)

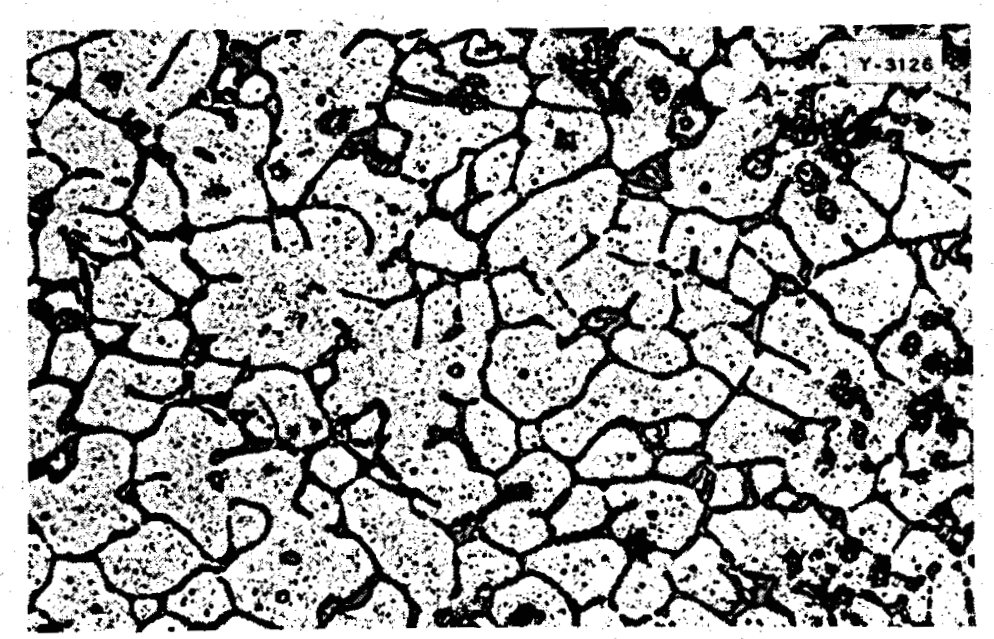

c - $94 \% \mathrm{Th}-6 \% \mathrm{Ti}$ (Original magnification $250 \mathrm{X}$; reduced to $155 \mathrm{X}$ in reproduction)

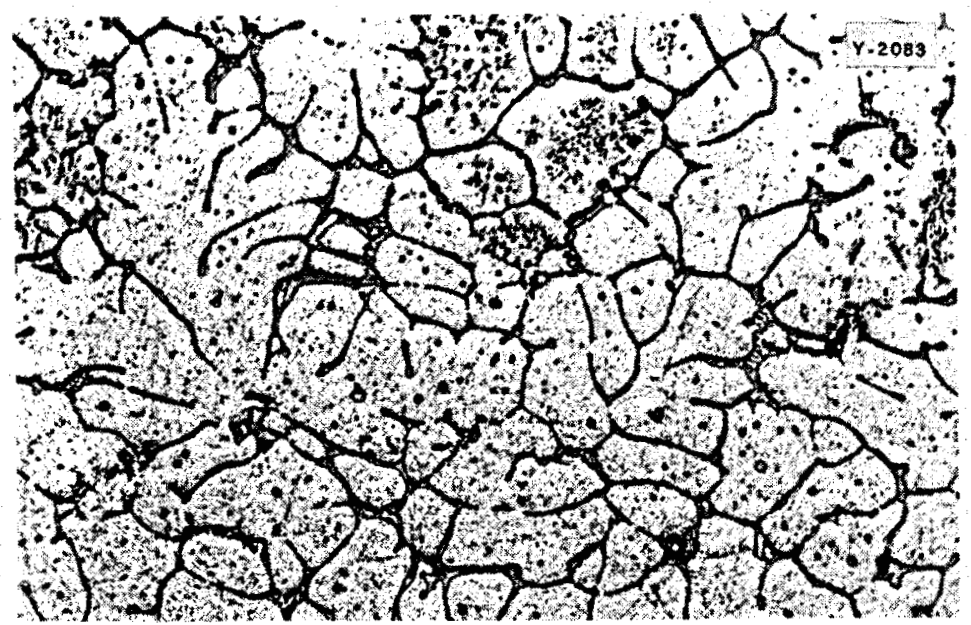

d - 92\% Th - $8 \%$ Ti (Original magnification $200 \mathrm{X}$; reduced to $124 \mathrm{X}$ in reproduction)

Fig. 55 - Photomicrographs of Th-Ti Alloys. 


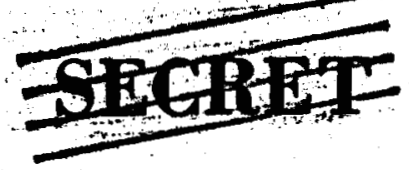

\section{INTERIM REPORT ON METALLURGY OF THORIUM AND THORIUM ALLOYS} (1)

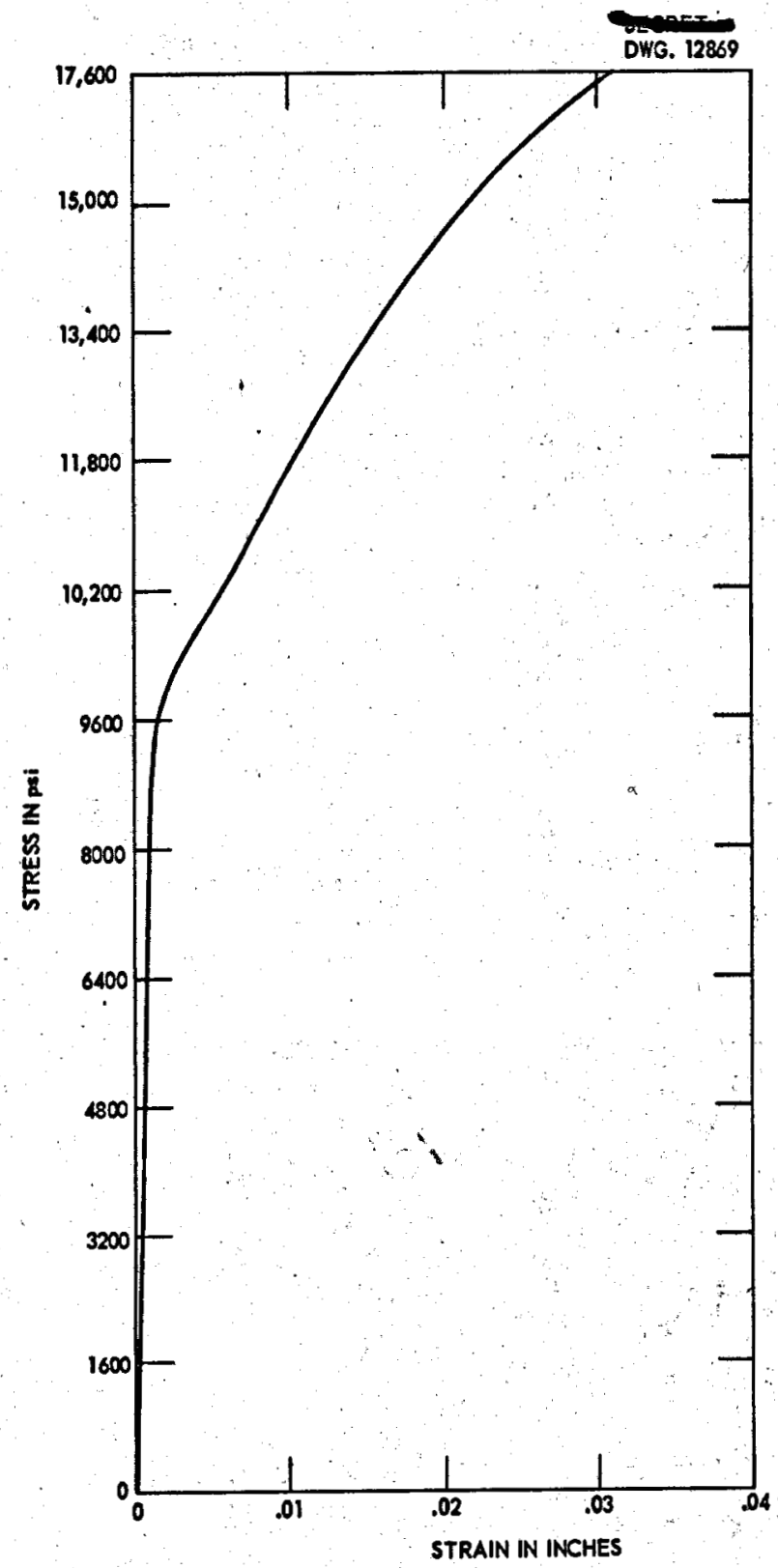

F16. 56 - Load-Elongation Curve for $2 \%$ TI-Th Alloy.

specimens machined from the plate. The specimens were annealed at $750^{\circ} \mathrm{C}$ for $1 / 2 \mathrm{hr}$ before testing. The results are shown in Table 15.

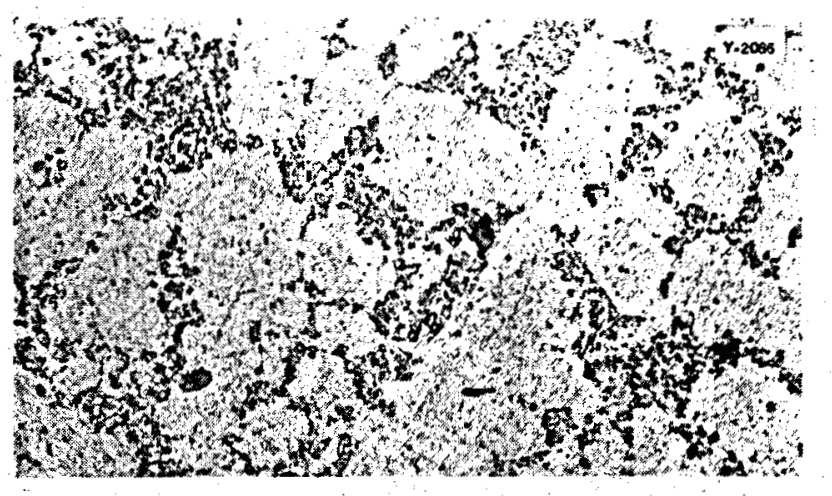

- $98 \%$ Th - $2 \%$ Cr (Original magnification

Hardness: $R_{B} 58$

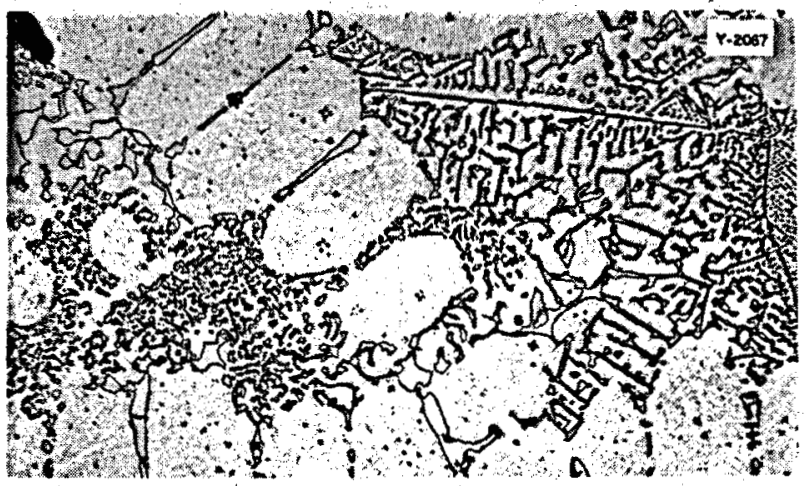

b. $98 \%$ Th - $2 \%$ Cr (Original magnification

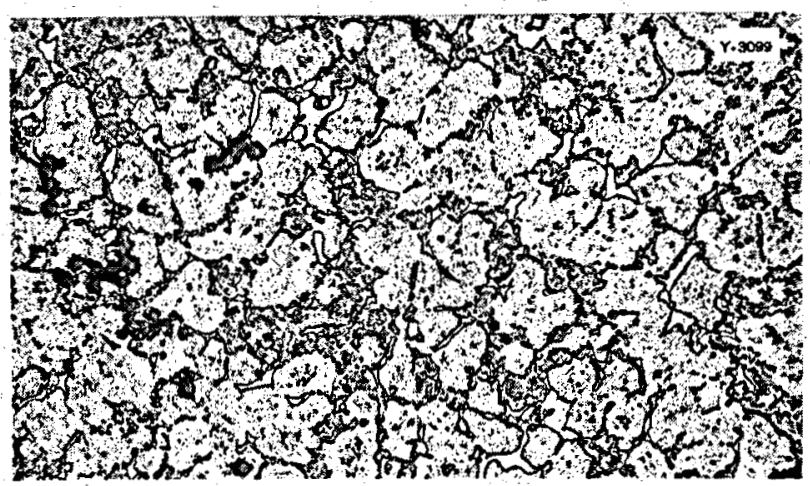

c- $96 \%$ Th $4 \%$ Cr $(0 x$ iginal magnification

F1g. 57 - Photomicrograpbs of Th-Cr Alloys. 


\section{INTER IM REPORT ON METALLURGY OF THORIUM AND THORIUM ALLOYS}

TABLE 15

Tensile Test Data for Annealed Thorium-Chromium Alloys

\begin{tabular}{|c|c|c|c|c|c}
\hline Specimen No. & $\begin{array}{c}\text { Cr Content } \\
\text { Per cent }\end{array}$ & $\begin{array}{c}\text { Prop. Limit } \\
\text { Psi }\end{array}$ & $\begin{array}{c}\text { Per cent } \\
\text { Elongation in } \\
\text { 2-ingage length }\end{array}$ & $\begin{array}{c}\text { Per cent } \\
\text { Reduction } \\
\text { in Area }\end{array}$ & $\begin{array}{c}\text { Tensile } \\
\text { Strength } \\
\text { Psi }\end{array}$ \\
\hline A472 A & 2 & 35,200 & 25 & 35 & 47,360 \\
A472 B & 2 & 38,095 & 25 & 31 & 52,220 \\
A472 C & 2 & 40,470 & 22 & 10 & 53,330 \\
Ames Th & 0 & 22,000 & 44 & 64 & 32,160 \\
Ames Th & 0 & 23,600 & 47 & 40 & 32,000 \\
Ames Th & 0 & 23,000 & 50 & 42 & 32,320 \\
Ames Th & & & & & \\
(Cold-work 85\%) & & & & & \\
\hline
\end{tabular}

The proportional limit and tensile strength of the $2 \% \mathrm{Cr}$ alloy is higher than for the case of severely cold worked Ames thorium. A yield point was observed in the load elongation curves of all the $\mathrm{Cr}$. alloys.

Th-Nb - It has been reported that small additions of niobium to cast thorium improves its workability by tying up the carbon present. (1) A eutectic was reported on the thoriumrich side of the equilibrium diagram, melting at approximately $1315^{\circ} \mathrm{C}$.

Alloys containing $2,4,6$, and $9 \%$ niobium by weight were prepared. These alloys were found to be slightly. softer ( $R_{B}$ 46-62): than Ames thorium. As had been previously reported, the alloys were found to be workable by coldrolling the as-cast ingot. The workability continued to improve as the niobium content was increased. The $2 \%$ alloy cracked after cold-rolling to $36 \%$ reduction. The 4 and $6 \%$ alloys were rolled into sheet for preparation of specimens, and were in good condition after $75 \%$ reduction. The $9 \%$ alloy was cold-rolled to $97 \%$ reduction before cracking. The photomicrographs of the $\mathrm{Nb}$ alloys shown in Fig. 58 would indicate considerable solubility of $\mathrm{Nb}$ in thorium, since there appears to be very little second phase present in the $2 \%$ alloy.

$T h-M n$ - It has been reported that addition of $1 \%$ Mn to thorium improves cold-rolling properties and lowers the lattice parameter. (1) There is evidence of a eutectic at $911^{\circ} \mathrm{C}$ at a composition of more than $20 \% \mathrm{Mn}$.

Alloys were prepared with nominal compositions of $2,4,6$, and $8 \% \mathrm{Mn}$. Since manganese has a relatively high vapor pressure, there was considerable loss of $\mathrm{Mn}$ during the vacuum melting and casting. The Mn alloys were found to be workable by cold-rolling but inferior to the $T i$ and $Z r$ alloys. A photomicrograph of the $4 \%$ alloy is shown in Fig. 59b. The appearance of 


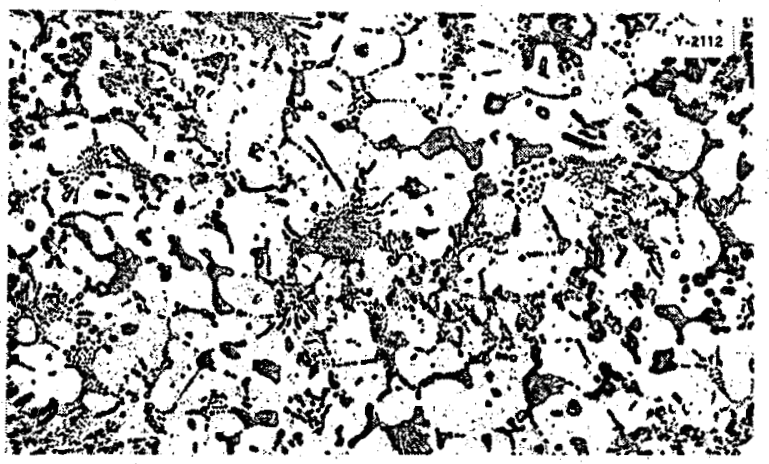

a - 98\% Th - $2 \% \mathrm{Nb}$ (Original magnification $500 X_{i}$ reduced to $248 X$ in reproduction)

Hardness: $R_{B} 54$ DPH 91

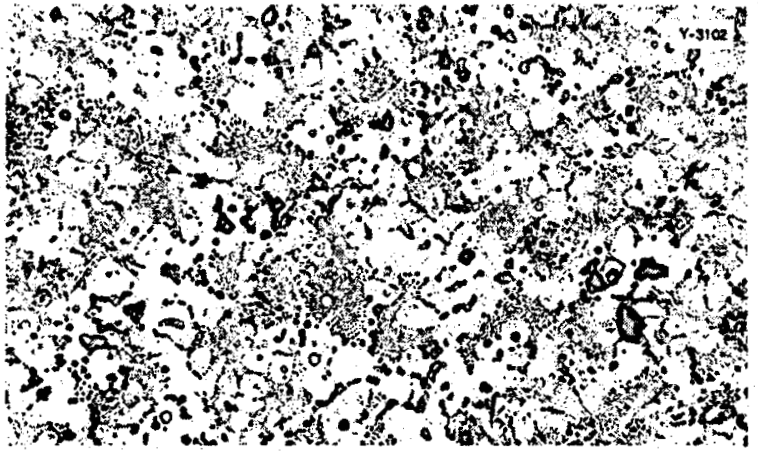

b - $96 \% \mathrm{Th}-4 \% \mathrm{Nb}$ (Original magnification $250 X$; reduced to $128 \mathrm{X}$ in reproduction)

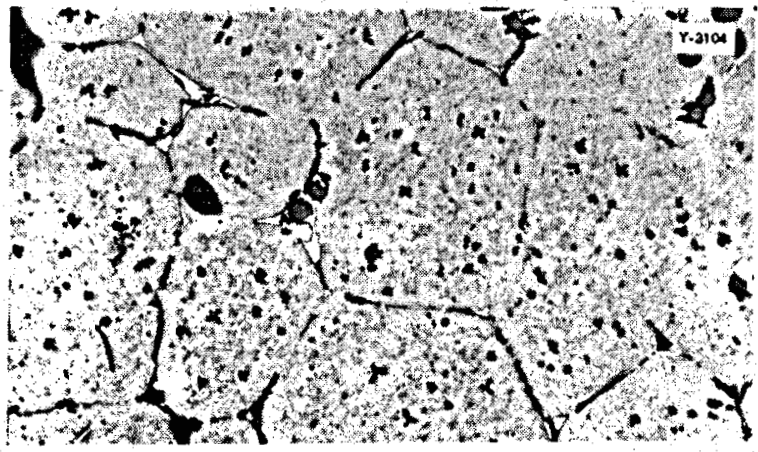

c $-94 \%$ Th - $6 \%$ Nb (Original magnification

Fig. 58 - Photomicrographs of Th-Cb Alloys.

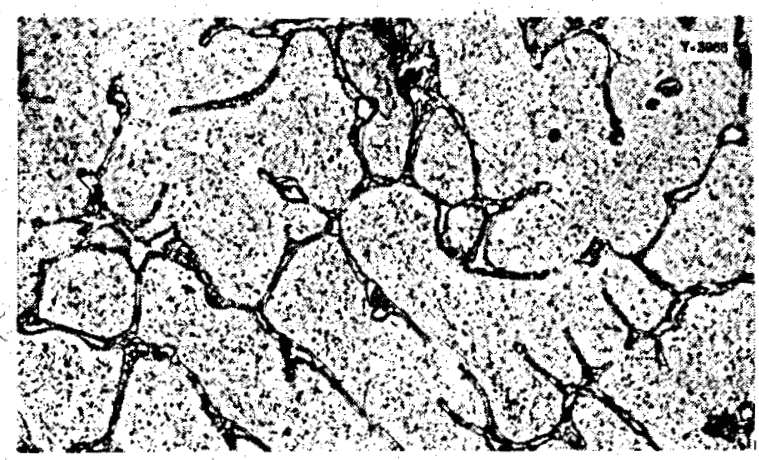

- 98\% Th - 2\% Mn (Original wagnification $250 X$; reduced to $128 \mathrm{X}$ in reproduction)

Vacuum melted and cast

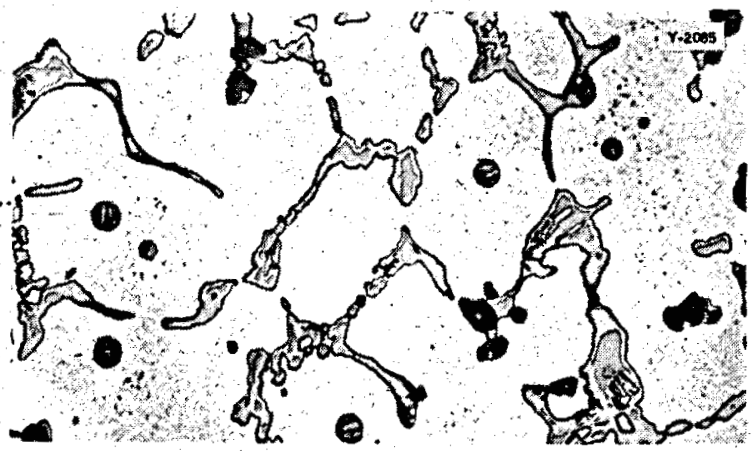

b - 96\% Th - 4\% Mn (Original magnificetion $500 X_{;}$reduced to $240 X$ in reproduction)

Vacuum melted and cast

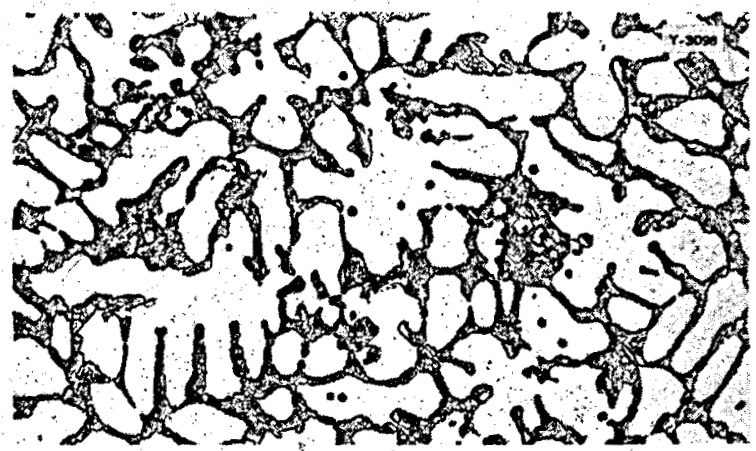

c $-96 \% \mathrm{Th}-4 \% \mathrm{Mn}$ (Original magnification $250 X_{;}$reduced to $128 \mathrm{X}$ in reproduction)

Melted in vacuum, cast under argon

F1g: 59-Photomicrographs of Th-Mn Alloys.

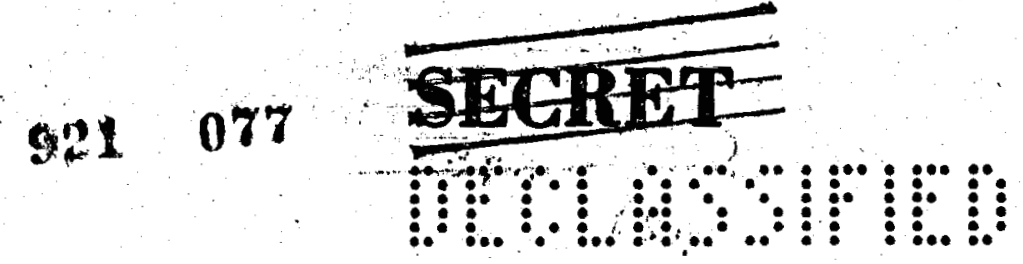


the network constituent suggests peritectic reaction. In order to prevent Mn loss a $4 \%$ alloy was prepared by melting the thorium in vacuum and admitting purified argon to atmospheric pressure before adding the manganese and casting. The photomicrograph of this alloy (Fig. -59c) showed the same type of structure as the vacuum-cast alloy.

Th-Ce:- Complete solid and liquid solubility of Ce and Th has been reported. $(1.5 .6)$ However, extremely cored dendrites are usually found in the microstructure, and long-time homogenization treatments are necessary to produce single-phase alloys:

Alloys containing $2,4,6$, and $8 \%$ Ce were prepared. As may be seen in Fig. 60 , there was not a continuous network of second phase present in any of the alloys, and it was not considered necessary to homogenize the cast ingots. The ingots were coldrolled as cast. Cracking started at about $5 \%$ reduction and at $15 \%$ reduction, and the material was of no value. All of the alloys behaved about the same during rolling regardless of composition. The maximum cold-rolling passible was about $30 \%$ reduction in thickness. Apparently, intergranular cracking caused failure when the alloy was cold-rolled.

The Ce alloys were slightly harder than Ames thorium.

$T h-S i-Z r$ and $T h-T i-Z r$ - A series of ternary alloys were prepared of Th$\mathrm{Si}-\mathrm{Zr}$ and Th-Ti-Zr. The hardness and approximate melting points of the alloys are shown in Table 16. It was found that all alloys containing silicon were brittle and impossible to fabricate by cold-rolling. However,

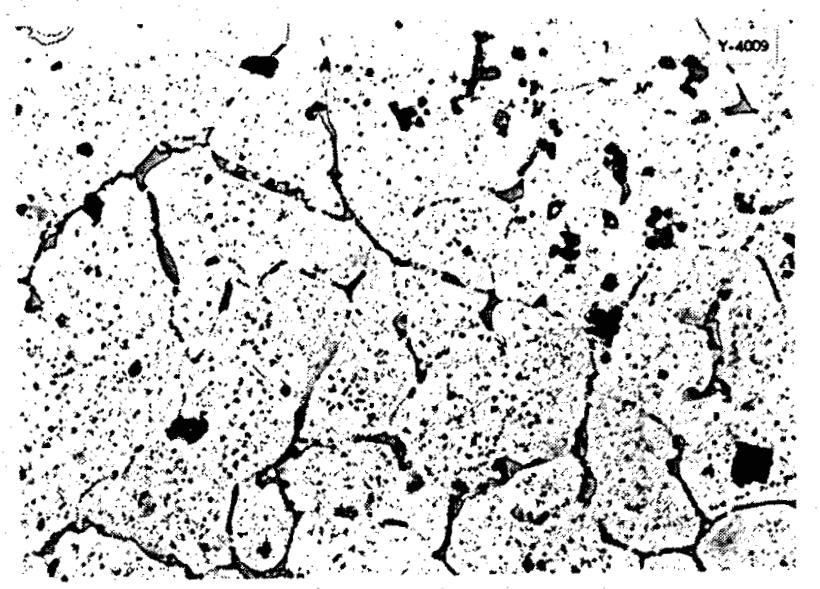

a $-98 \% \mathrm{Th}=2 \% \mathrm{Ce}$ (Original magnification $250 \mathrm{X}$; reduced to $120 \mathrm{X}$ in reproduction)

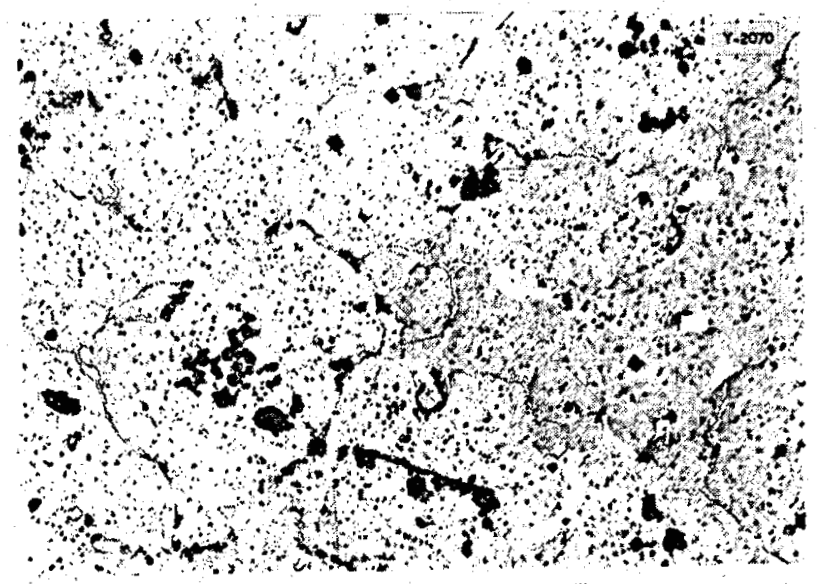

b - $92 \% \mathrm{Th}-8 \% \mathrm{Ce}$ (Original magnification $250 \mathrm{X}_{\text {; }}$ reduced to $120 \mathrm{X}$ in reproduction)

Fig. 60-Photomicrographs of Th-Ce Alloys.

the series of Th-Si-Zr alloys showed a continuous decrease of hardness with increasing zirconium content. The $4 \%$ $\mathrm{Zr}$ - $1 \% \mathrm{Si}$ alloy was relatively soft

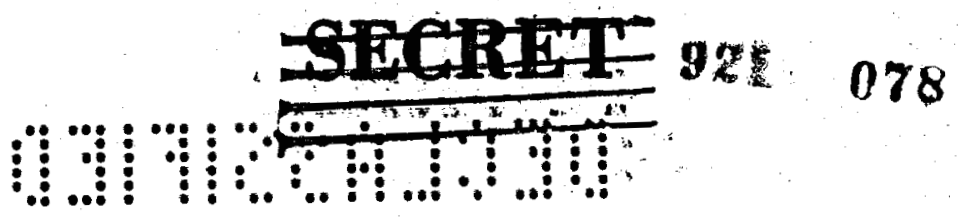




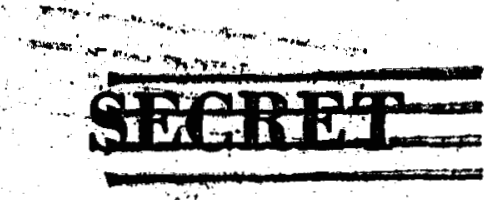

\section{INTER IM REPORT ON METALLURGY OF THORIUM AND THORIUM ALLOYS}

TABIE 16

Data for Ternary Thorium Alloys

\begin{tabular}{c|c|c|c|c}
\hline \multirow{2}{*}{$\begin{array}{c}\text { Alloy } \\
\text { No. }\end{array}$} & Composition & $\begin{array}{c}\text { Approximate } \\
\text { Melting Point } \\
\left({ }^{\circ} \mathrm{C}\right)\end{array}$ & \multicolumn{2}{|c}{ Hardness } \\
\cline { 3 - 5 } A-543 & $1 \% \mathrm{Si}, 1 \% \mathrm{Zr}$ & 1265 & 138 & RB 80 \\
A-551 & $1 \% \mathrm{Si}, 2 \% \mathrm{Zr}$ & 1250 & 106 & RB 57 \\
A-556 & $1 \% \mathrm{Si}, 4 \% \mathrm{Zr}$ & 1225 & 76 & RB 41 \\
A-561 & $2 \% \mathrm{Si}, 1 \% \mathrm{Zr}$ & 1265 & 112 & RB 71 \\
A-566 & $4 \% \mathrm{Si}, 1 \% \mathrm{Zr}$ & & 116 & RB 75 \\
A-615 & $1 \% \mathrm{Ti}, 1 \% \mathrm{Zr}$ & 1305 & 58 & RH 91 \\
A-616 & $1 \% \mathrm{Ti}, 2 \% \mathrm{Zr}$ & 1300 & 64 & RH 96 \\
A-618 & $1 \% \mathrm{Ti}, 4 \% \mathrm{Zr}$ & 1290 & 116 & RH 110 \\
A-619 & $2 \% \mathrm{Ti}, 1 \% \mathrm{Zr}$ & 1405 & 49 & RH 91 \\
A-620 & $4 \% \mathrm{Ti}, 1 \% \mathrm{Zr}$ & 1330 & 70 & RH 94 \\
\hline
\end{tabular}

but could not be cold-rolled. The microstructure of this alloy, Fig. 61a, appeared to be very near a eutectic composition. An alloy containing $1.3 \%$ $\mathrm{Zr}$ and $1.4 \% \mathrm{Si}$ (Fig. 6Ib) showed a considerable amount of a hard brittle phase, and a $1 \% \mathrm{Zr}-2.4 \% \mathrm{Si}$ alloy (Fig. 6lc) showed large primary grains of the hard phase. The matrix was soft (DPH 85) as compared to the primary constituent (DPH 700-830). The compound was so brittle that it was very difficult to obtain a diamond pyramid impression without cracking the primary crystal's.

All of the $T h-T i-Z r$ alloys were soft and easily fabricated with the exception of a $1 \% \mathrm{Ti}-4 \% \mathrm{Zr}$ alloy, which had a diamord pyramid Vickers hardness number of 116 and cracked a fter only $5 \%$ reduction in thickness by cold-rolling. This alloy (Fig. 61d) was the only one of the series whose microstructure formed continuous network of a second phase which was very hard and brittle. The primary grains were exceptionally soft (DPH 5) so that failure apparently occurred because of the brittle intergranular phase.

All of the alloys of $\mathrm{Zr}-\mathrm{Ti}$ except the $4 \% \mathrm{Zr}-1 \% \mathrm{Ti}$ composition were rolled into plate and test specimens prepared. The results of tensile tests are shown on the following page. 


\section{INTER IM REPORT ON METALLURGY OF THORIUM AND THORIUM ALLOYS}

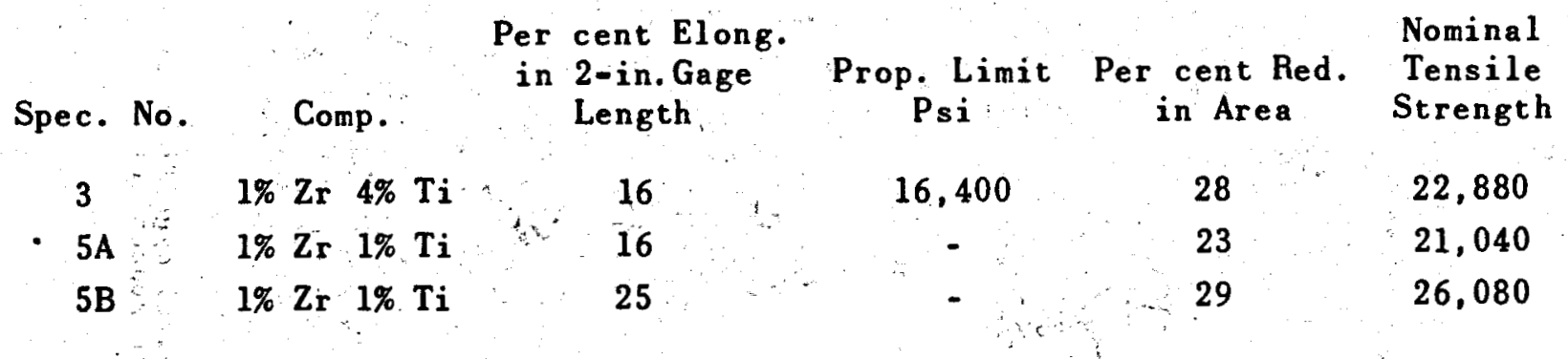

The proportional limit of the $1 \% \mathrm{Ti}$ $1 \% \mathrm{Zr}$ alloys was very low. The specimens apparently were creeping at very low stress leyels.

\section{CORROSION TESTS}

Since water is a commonly used coolant in reactors, samples of Ames thorium and alloys prepared from Ames thorium were subjected to static corrosion tests in distilled water. A temperature of $95^{\circ} \mathrm{C}$ was chosen as the maximum practicable temperature of water at atmospheric pressure. Samples measuring 1 in. by 1 in. by $1 / 8$ in. were prepared from annealed Ames thorium, cold-rolled Ames thorium, and Ames thorium containing from $2 \%$ to $6 \%$ of niobium, chromium, titarium, and zirconium. The samples were degreased, dried, and weighed prior to testing. The specimens were suspended individually from glass hooks in a battery jar containing 16 liters of distilled water. The heat was supplied with an electrically heated water bath which was controlled at $95^{\circ} \mathrm{C} \pm 1^{\circ} \mathrm{C}$. The samples were exposed for one month and the water was not changed during the entire exposure. The samples were removed and weighed without further treatment. There was no significant difference in the corrosion rates of Ames thorium and the alloys of thorium with the possible exception of the chromium alloys, which showed less corrosion than any of the other specimens. The data obtained are listed in Table 17 . 


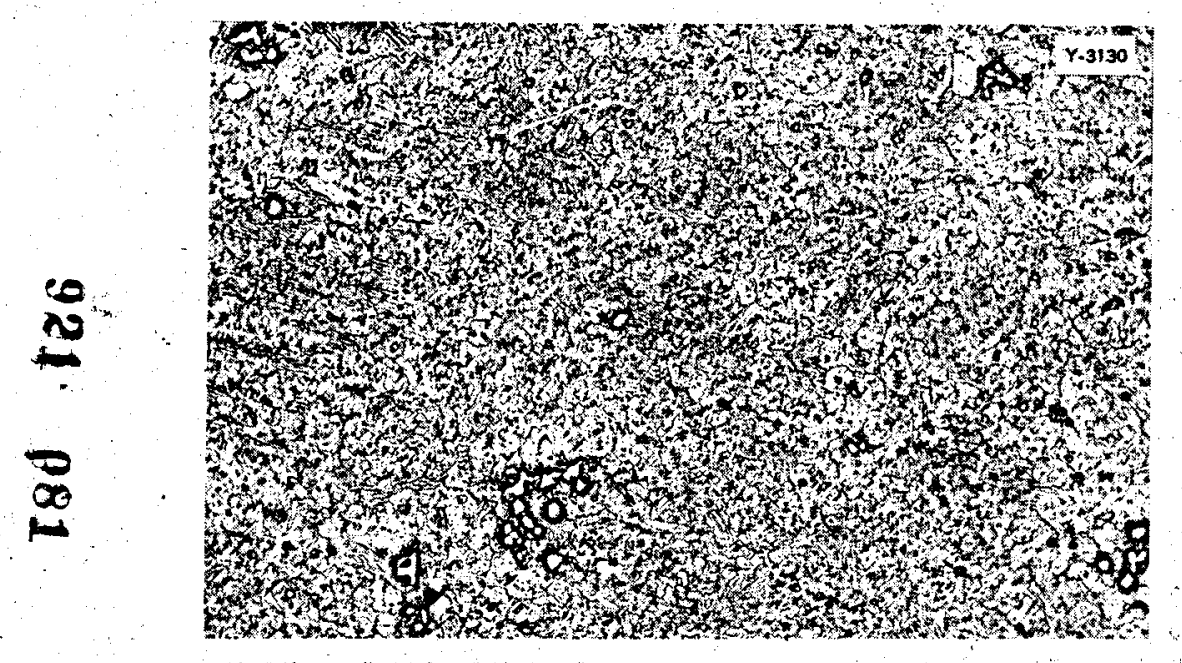
$95 \% \mathrm{Th}-1 \% \mathrm{Si}-4 \% \mathrm{Zr}$ (Original magnification
(O)

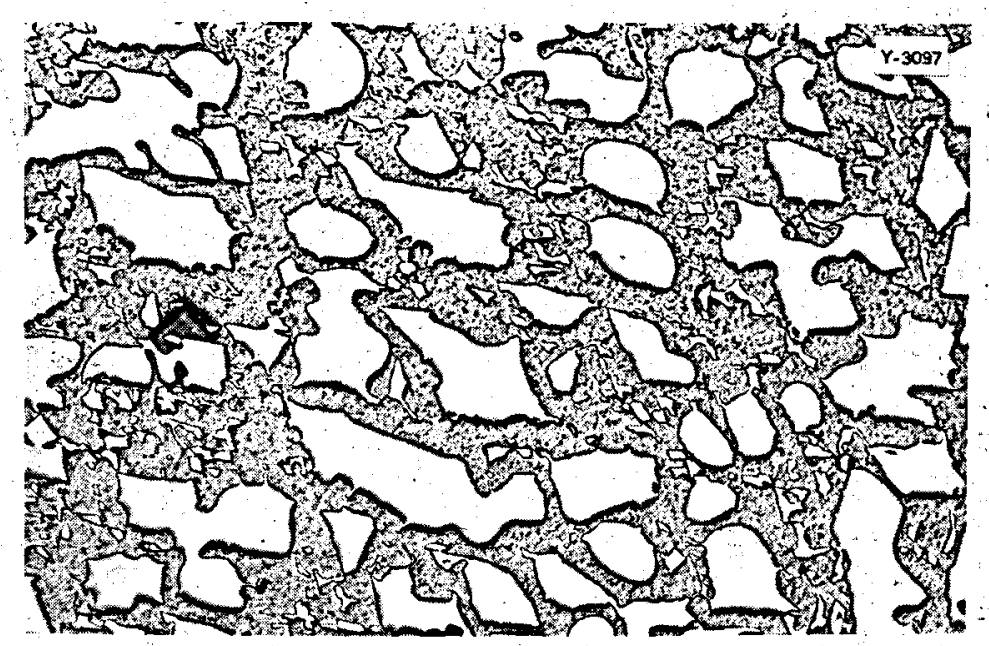
c $-95 \% \mathrm{Th}-4 \% \mathrm{Si}-1 \% \mathrm{Zr}_{\mathrm{r}}$ (Original magnification

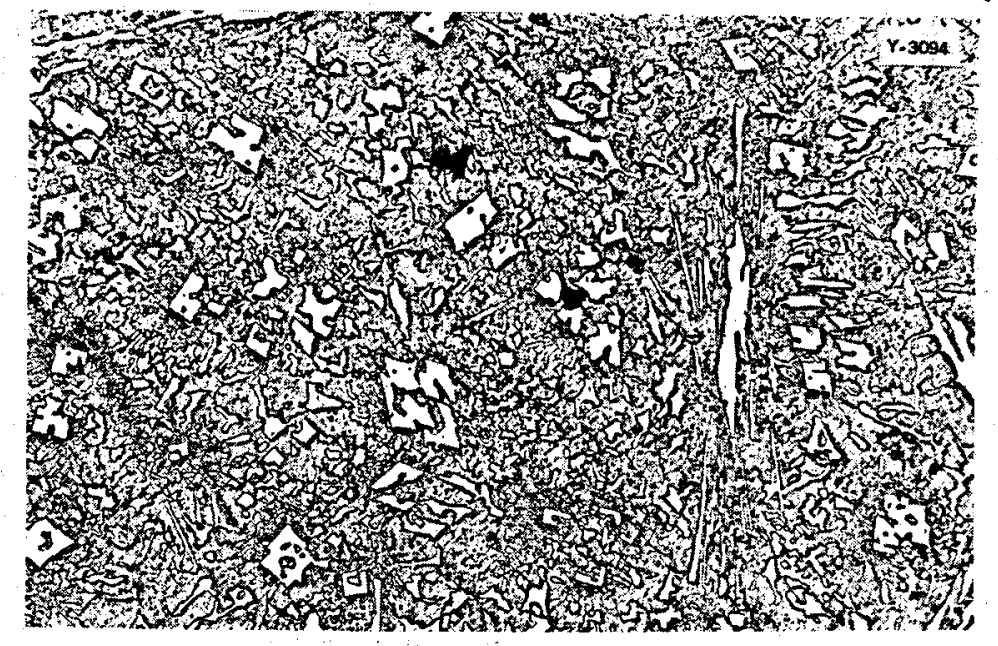

b - $97 \% \mathrm{Th}-1 \% \mathrm{Si}-2 \% \mathrm{Zr}_{\mathrm{r}}$ (Original magnification $250 \mathrm{X}$; reduced to $147.5 \mathrm{X}$ in reproduction)

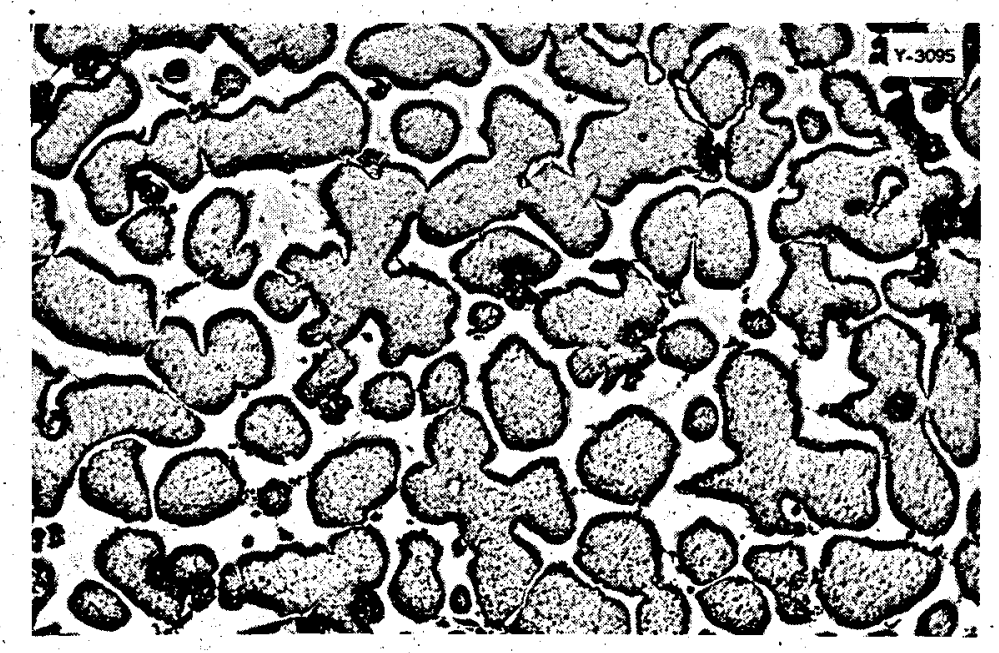

d $-95 \% \mathrm{Th}-1 \% \mathrm{Ti}-4 \% \mathrm{Zr}$ (Original magnification $250 \mathrm{X}$; reduced to $147.5 \mathrm{X}$ in reproduction) 


\section{METALLOGRAPHY OF THORIUM}

$\mathrm{T}$

HORIUM is difficult to polish because of its softness. Lead laps have been used, but were not found to be as satisfactory as hand-grinding on abrasive paper followed by polishing on silk cloth with levigated alumina.

Considerable difficulty has been experienced in satisfactorily etching thorium to show the grain boundaries. The most commonly recommended etch has been $50 \%$ glacial acetic acid and $50 \%$ orthophosphoric acid: It was found that this etch tends to stain the matrix and makes identification of individual grains difficult. However, a new technique has been developed for etching to show the grain boundaries.

The unmounted speciman was handground through a series of fine abrasive papers from 180 to $600 \mathrm{grit}$. The specimen was then polished on a silk clotb mounted on a motor-driven polishing disc. Medium-fine alumina powder was used to remove the grinding scratches caused by the papers. Final polishing was accomplished with an electrolyte of 1 part perchloric acid and 10 parts glacial acetic acid. The specimen (anode) was suspended, by a stainless steel clamp, vertically and at right angles to the stainless steel cathode. The cathode-to-anode distance was approximately 3 in. The polishing period was 3 to 5 sec at 50 volts with a current density of 4 amp psi. This short time allowed slight metal removal with little attack on inclusions. The specimen was removed from the cell with the current on and immediately immersed in a small amount of fresh electrolyte to remove a loose film formed during electrolysis. Due to the etch-polish attack, examination was madewithout further etching. This technique was very satisfactory for the pure thorium metal, but was found unsuitable for polishing thorium alloys.

Since no good method of etching alloys was found, an alternate polishand-etch technique was used with an etchant of $50 \%$ glacial acetic acid and $50 \%$ phosphoric acid. Some of the binary alloys such as $\mathrm{Th}-\mathrm{C}$ and $\mathrm{Th}-\mathrm{Al}$ are attacked by moisture, and it was necessary to polish and etch in the absence of water. 
INTER IM REPORT ON METALLURGY OF THORIUM AND THORIUM ALLOYS

\section{BIBLIOCRAPHY}

(1) H: A. Wilhelm, A. S. Newton, A. H. Doane, and C. Neher, CT 3714 Thorium Metallurgy, (Feb. 22, 1946).

(2) W. R. Kittredge, MUC-RWY-No, 73 (March 22, 1945).

(3) A. J. Bradley and A. H. Jay, Proc. Phys. Soc. (London) 44, $563(1932)$.

(4) H. L. Kain and A. H. Cottrell, Proc. Phys, Soc. (B), 63, 339, (1950).

(5) F. Foote, E. W. Brugmann, and J. H. Chapin, CT 2787 (March 24, 1945).

(6) F. Foote, E. W. Brugmann, and J. H. Chapin, CT 2873 (April . 7, 1945).

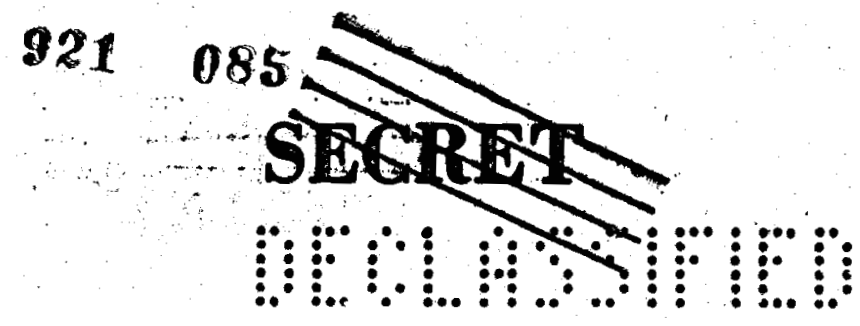




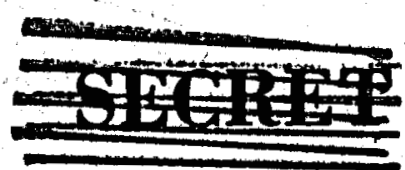

INTER IM REPORT ON METALLURGY OF THORIUM AND THORIUM ALLOYS

APPENDIX

921.087 


\section{INTERIM REPORT ON METALLURGY OF THORIUM AND THORIUM ALLOYS}

TABLE 1

Thermal Cycling of Ames Thorium in NaK between $100^{\circ} \mathrm{C}$ and $500^{\circ} \mathrm{C}$

\begin{tabular}{|c|c|c|c|c|c|c|c|c|c|c|}
\hline $\begin{array}{c}\text { Annealed } \\
\text { Thorium } \\
\text { No. } 1\end{array}$ & Original & $\begin{array}{c}100 \\
\text { Cycles }\end{array}$ & $\begin{array}{c}300 \\
\text { Cycles }\end{array}$ & $\begin{array}{c}400 \\
\text { Cycles }\end{array}$ & $\begin{array}{c}500 \\
\text { Cycles }\end{array}$ & $\begin{array}{c}600 \\
\text { Cycles }\end{array}$ & $\begin{array}{c}700 \\
\text { Cycles }\end{array}$ & $\begin{array}{c}800 \\
\text { Cycles }\end{array}$ & $\begin{array}{c}900 \\
\text { Cycles }\end{array}$ & $\begin{array}{c}1000 \\
\text { Cycle: }\end{array}$ \\
\hline $\begin{array}{l}\text { Length (in) } \\
\text { Diame ter (in) } \\
\text { Weight (gm) } \\
\Delta \mathrm{I} \text { (in.) } \\
\Delta \mathrm{d} \text { (in) } \\
\Delta \mathrm{w} \text { (gm) } \\
\text { Wt. Change (x) }\end{array}$ & \multirow[t]{2}{*}{$\begin{array}{c}4.012 \\
0.750 \\
333.876 \\
= \\
- \\
-\end{array}$} & \multirow[t]{2}{*}{$\begin{array}{r}4.026 \\
0.752 \\
+ \\
+0.014 \\
0.002 \\
- \\
-\end{array}$} & \multirow[t]{2}{*}{$\begin{array}{r}4.051 \\
0.760 \\
334.133 \\
+0.039 \\
0.010 \\
+0.257 \\
0.07\end{array}$} & \multirow[t]{2}{*}{$\begin{array}{c}4.061 \\
0.757 \\
330.965 \\
+0.049 \\
0.007 \\
-2.960 \\
0.88\end{array}$} & \multirow[t]{2}{*}{$\begin{array}{r}4.075 \\
0.772 \\
324.898 \\
+0.063 \\
0.022 \\
-8.978 \\
2.69\end{array}$} & \multirow[t]{2}{*}{$\begin{array}{r}4.091 \\
0.763 \\
322.851 \\
+0.079 \\
0.013 \\
-11.025 \\
3.3\end{array}$} & \multirow[t]{2}{*}{$\begin{array}{r}4.091 \\
0.763 \\
320.303 \\
+0.079 \\
0.013 \\
-13.573 \\
4.07\end{array}$} & \multirow[t]{2}{*}{$\begin{array}{r}4.097 \\
0.769 \\
319.619 \\
+0.085 \\
0.019 \\
-14.257 \\
4.27\end{array}$} & \multirow[t]{2}{*}{$\begin{array}{r}4.110 \\
0.769 \\
317.500 \\
+0.098 \\
0.019 \\
-16.376 \\
4.9\end{array}$} & \multirow[t]{2}{*}{$\begin{array}{r}4.099 \\
0.768 \\
316.653 \\
+0.087 \\
0.016 \\
-17.223 \\
5.15\end{array}$} \\
\hline $\begin{array}{c}\text { Annealed } \\
\text { Thorium } \\
\text { No. } 2\end{array}$ & & & & & & & & & & \\
\hline $\begin{array}{l}\text { Length (in) } \\
\text { Diameter (in) } \\
\text { Weight (gm) } \\
\Delta 1 \text { (in) } \\
\Delta d \text { (in.) } \\
\Delta \text { (gin) } \\
\text { Wt. Change (\%) }\end{array}$ & \multirow[t]{2}{*}{$\begin{array}{r}4.005 \\
0.750 \\
333.876 \\
- \\
= \\
=\end{array}$} & \multirow[t]{2}{*}{$\begin{array}{c}4.021 \\
0.752 \\
- \\
+0.016 \\
+0.002 \\
\vdots\end{array}$} & \multirow[t]{2}{*}{$\begin{array}{c}4.043 \\
0.763 \\
334.350 \\
+0.038 \\
+0.013 \\
+0.574 \\
-0.11\end{array}$} & \multirow[t]{2}{*}{$\begin{array}{r}4.048 \\
0.761 \\
330.470 \\
+0.043 \\
+0.011 \\
-3.406 \\
1.02\end{array}$} & \multirow[t]{2}{*}{$\begin{array}{r}4.064 \\
0.762 \\
327.405 \\
+0.059 \\
+0.012 \\
-6.471 \\
1.94\end{array}$} & \multirow[t]{2}{*}{$\begin{array}{r}4.081 \\
0.765 \\
325.585 \\
+0.076 \\
+0.015 \\
-8.291 \\
2.48\end{array}$} & \multirow[t]{2}{*}{$\begin{array}{r}4.080 \\
0.767 \\
323.696 \\
+0.075 \\
+0.017 \\
-10.180 \\
3.04\end{array}$} & \multirow[t]{2}{*}{$\begin{array}{r}4.069 \\
0.774 \\
322.813 \\
+0.064 \\
+0.024 \\
-11.063 \\
3.31\end{array}$} & \multirow[t]{2}{*}{$\begin{array}{r}4.013 \\
0.775 \\
316.370 \\
+0.098 \\
+0.025 \\
-17.506 \\
5.24\end{array}$} & \multirow[t]{2}{*}{$\begin{array}{r}4.102 \\
0.764 \\
313.901 \\
+0.097 \\
+0.014 \\
-19.975 \\
5.98\end{array}$} \\
\hline $\begin{array}{l}\text { Cold-Rolled } \\
\text { Thorium } \\
\text { No. } 1\end{array}$ & & & & & & & & & & \\
\hline $\begin{array}{l}\text { Length (in) } \\
\text { Diameter.(in) } \\
\text { Weight (gm) } \\
\Delta l \text { (in) } \\
\Delta d \text { (in) } \\
\Delta w \text { (gm) } \\
\text { Wt. Change (x) }\end{array}$ & \multirow[t]{2}{*}{$\begin{array}{c}4.032 \\
0.498 \\
150.301 \\
- \\
- \\
-\end{array}$} & \multirow[t]{2}{*}{$\begin{array}{r}4.031 \\
0.501 \\
150.169 \\
-0.001 \\
+0.003 \\
-0.132 \\
0.08\end{array}$} & \multirow{2}{*}{. } & & \multirow[t]{2}{*}{$\begin{array}{r}4.034 \\
0.493 \\
145.960 \\
+0.002 \\
-0.005 \\
-4.341 \\
2.9\end{array}$} & \multirow[t]{2}{*}{$\begin{array}{r}4.030 \\
0.505 \\
145.496 \\
- \\
+0.007 \\
-4.805 \\
3.19\end{array}$} & \multirow[t]{2}{*}{$\begin{array}{r}4.035 \\
0.502 \\
138.792 \\
+0.003 \\
+0.004 \\
-11.509 \\
7.66\end{array}$} & \multirow[t]{2}{*}{$\begin{array}{r}4.035 \\
0.497 \\
134.240 \\
+0.003 \\
-0.001 \\
-16.061 \\
10.68\end{array}$} & & \multirow[t]{2}{*}{$\begin{array}{r}4.022 \\
0.493 \\
127.487 \\
-0.010 \\
-0.005 \\
-22.814 \\
15.00\end{array}$} \\
\hline $\begin{array}{l}\text { Cold-Aolled } \\
\text { Thorium } \\
\text { No. } 2\end{array}$ & & & & & & & & & & \\
\hline $\begin{array}{l}\text { Length (in) } \\
\text { Diameter (in) } \\
\text { Weight (gm) } \\
\Delta l \text { (in.) } \\
\Delta d \text { (in.) } \\
\Delta w \text { (gm) } \\
\text { Wt. Change (\%) }\end{array}$ & \multirow[t]{2}{*}{$\begin{array}{r}4.009 \\
0.497 \\
148.776 \\
=- \\
= \\
=\end{array}$} & \multirow[t]{2}{*}{$\begin{array}{r}4.018 \\
0.502 \\
149.627 \\
+0.009 \\
+0.005 \\
+0.851 \\
0.57\end{array}$} & & & \multirow[t]{2}{*}{$\begin{array}{r}4.023 \\
0.505 \\
145.892 \\
+0.014 \\
+0.008 \\
-2.884 \\
1.94\end{array}$} & \multirow[t]{2}{*}{$\begin{array}{r}4.028 \\
0.514 \\
145.321 \\
+0.019 \\
+0.017 \\
-3.455 \\
2.32\end{array}$} & \multirow[t]{2}{*}{$\begin{array}{r}4.020 \\
0.510 \\
140.391 \\
+0.011 \\
+0.013 \\
-8.385 \\
5.64\end{array}$} & \multirow[t]{2}{*}{$\begin{array}{r}4.023 \\
0.500 \\
136.623 \\
+0.014 \\
+0.003 \\
-12.153 \\
8.17\end{array}$} & & \multirow[t]{2}{*}{$\begin{array}{r}4.019 \\
0.494 \\
130.411 \\
+0.010 \\
-0.006 \\
-18.365 \\
12.34\end{array}$} \\
\hline $\begin{array}{l}\text { Cold-Swaged } \\
\text { Thorium }\end{array}$ & & & & & & & & & & \\
\hline $\begin{array}{l}\text { Length (in) } \\
\text { Diame ter (in) } \\
\text { Weight (gm) } \\
\Delta i \text { (in) } \\
\Delta d \text { (in) } \\
\Delta \text { w (gm) } \\
\text { Wt. Change (g) }\end{array}$ & \multirow[t]{2}{*}{$\begin{array}{r}3.981 \\
0.440 \\
114.615 \\
- \\
= \\
-\end{array}$} & \multirow[t]{2}{*}{$\begin{array}{r}3.955 \\
0.432 \\
114.203 \\
-0.026 \\
-0.008 \\
-0.412 \\
0.36\end{array}$} & & & \multirow[t]{2}{*}{$\begin{array}{r}3.974 \\
0.447 \\
110.316 \\
-0.007 \\
+0.007 \\
-4.299 \\
3.75\end{array}$} & $\begin{array}{r}3.980 \\
0.452 \\
109.753 \\
+0.001 \\
+0.012 \\
-4.962 \\
4.32\end{array}$ & $\begin{array}{r}3.987 \\
0.447 \\
107.600 \\
+0.006 \\
+0.007 \\
-7.015 \\
6.12\end{array}$ & $\begin{array}{r}3.995 \\
0.448 \\
103.630 \\
+0.014 \\
+0.008 \\
-10.985 \\
9.58\end{array}$ &. & $\begin{array}{r}3.995 \\
0.436 \\
98.301 \\
+0.014 \\
-0.004 \\
-16.314 \\
13.95\end{array}$ \\
\hline $\begin{array}{c}\text { As-Extruded } \\
\text { Thoriuut }\end{array}$ & & & & & & & & & & \\
\hline $\begin{array}{l}\text { Length (in) } \\
\text { Diameter (in) } \\
\text { Weight (gm) } \\
\Delta_{\text {l (in) }} \\
\Delta_{d} \text { (in.) } \\
\Delta_{w} \text { (gm) } \\
\text { Wt. Change (g) }\end{array}$ & $\begin{array}{r}4.030 \\
0.485 \\
144.550 \\
= \\
= \\
=\end{array}$ & $\begin{array}{r}4.060 \\
0.491 \\
145.204 \\
+0.030 \\
+0.006 \\
+0.654 \\
0.45\end{array}$ & & & $\begin{array}{r}4.106 \\
0.491 \\
140.405 \\
+0.076 \\
+0.006 \\
-4.145 \\
2.87\end{array}$ & $\begin{array}{r}4.106 \\
0.495 \\
139.929 \\
+0.076 \\
+0.010 \\
-4.621 \\
3.19\end{array}$ & $\begin{array}{r}4.119 \\
0.494 \\
134.904 \\
+0.084 \\
+0.009 \\
-9.646 \\
6.67\end{array}$ & $\begin{array}{r}4.134 \\
0.492 \\
131.192 \\
+0.104 \\
+0.007 \\
-13.358 \\
9.24 \\
\end{array}$ & & $\begin{array}{r}4.155 \\
0.483 \\
124.232 \\
+0.125 \\
-0.002 \\
-20.318 \\
14.05\end{array}$ \\
\hline
\end{tabular}




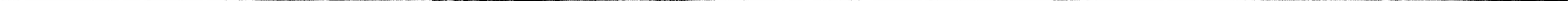

